\title{
Hydration of Aliphatic Nitriles Catalyzed by an Osmium Polyhydride: Evidence for an Alternative Mechanism
}

Juan C. Babón, Miguel A. Esteruelas, * Ana M. López, and Enrique Oñate

Departamento de Química Inorgánica, Instituto de Síntesis Química y Catálisis Homogénea (ISQCH), Centro de Innovación en Química Avanzada (ORFEO-CINQA), Universidad de Zaragoza-CSIC, 50009 Zaragoza, Spain

* Corresponding author's e-mail address: maester@unizar.es

\section{Contents:}

Experimental Section: General Information............................. S2

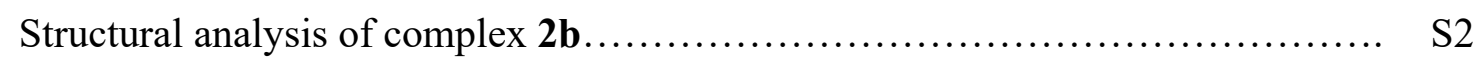

Computational details............................................. S3

Analytical data of the isolated amides.................................. S3

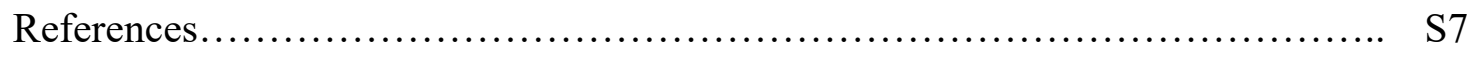

${ }^{1} \mathrm{H}$ NMR spectra of the reaction crude of the catalytic nitrile hydrations,

${ }^{1} \mathrm{H},{ }^{13} \mathrm{C}\left\{{ }^{1} \mathrm{H}\right\}$ APT NMR, and IR spectra of the amides...................... S10

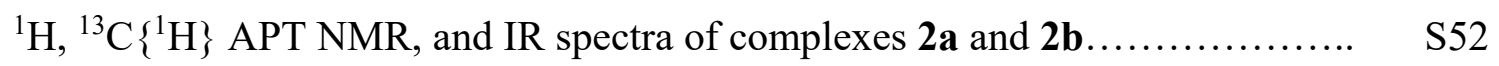

Energies of computed structures..................................... S56

Comparative tables of metal-catalyzed nitrile hydration............................ S64 
Experimental Section: General information. All manipulations were performed with rigorous exclusion of air at an argon/vacuum manifold using standard Schlenk-tube or glovebox techniques. Solvents were dried by the usual procedures and distilled under argon prior to use or obtained oxygen- and water-free from an MBraun solvent purification apparatus. THF- $d 8$ was stored over sodium in the glovebox. Complex $\mathrm{OsH}_{6}\left(\mathrm{P}^{\mathrm{i}} \mathrm{Pr}_{3}\right)_{2}$ (1) was prepared according to the published method. ${ }^{1}$ Nitriles were purchased from commercial sources and distilled in a Kugelrohr distillation oven. NMR spectra were recorded on a Bruker ARX 300, Bruker Avance $300 \mathrm{MHz}$, or a Bruker Avance $400 \mathrm{MHz}$ instruments. Chemical shifts (expressed in parts per million) are referenced to residual solvent peaks $\left({ }^{1} \mathrm{H},{ }^{13} \mathrm{C}\left\{{ }^{1} \mathrm{H}\right\}\right)$ and external $\mathrm{H}_{3} \mathrm{PO}_{4}\left({ }^{31} \mathrm{P}\left\{{ }^{1} \mathrm{H}\right\}\right)$ or $\mathrm{CFCl}_{3}\left({ }^{19} \mathrm{~F}\right)$. Coupling constants $J$ are given in Hertz. High-resolution (HRMS) electrospray mass spectra were acquired using a MicroTOF-Q hybrid quadrupole timeof-flight spectrometer (Bruker Daltonics, Bremen, Germany). C, H, and N analyses were carried out in a Perkin-Elmer 2400-B Series II CHNS-Analyzer. Attenuated total reflection infrared spectra (ATR-IR) of solid samples were run on a Perkin-Elmer Spectrum 100 FT-IR spectrometer.

Structural analysis of complex 2b. X-ray data were collected on a Bruker APEX DUO diffractometer equipped with a normal or fine focus, and $2.4 \mathrm{~kW}$ sealed tube source (Mo radiation, $\lambda=0.71073 \AA$ ). Data were collected over the complete sphere covering $0.3^{\circ}$ in $\omega$. Data were corrected for absorption by using a multiscan method applied with the SADABS program. ${ }^{2}$ The structures were solved by Patterson or direct methods and refined by full-matrix least squares on $\mathrm{F}^{2}$ with SHELXL2016, ${ }^{3}$ including isotropic and subsequently anisotropic displacement parameters. The hydrogen atoms were observed in the last Fourier Maps or calculated and refined freely or using a restricted riding model. The hydride ligands were observed in the difference Fourier maps and refined with a restrained distance to osmium atoms.

Crystal data for $\mathbf{2 b}: \mathrm{C}_{23} \mathrm{H}_{55} \mathrm{NOOsP}_{2}, \mathrm{M}_{\mathrm{w}}$ 613.82, yellow, irregular block $(0.135$ x 0.148 x $0.313 \mathrm{~mm}^{3}$ ), monoclinic, space group P21/c, a: 9.3498(7) $\AA, b: 29.037(2) \AA, c$ : 11.1353(8) A, $\beta: 112.5400(10)^{\circ}, V=2792.2(4) \AA^{3}, Z=4, Z^{\prime}=1$, Dcalc: $1.460 \mathrm{~g} \mathrm{~cm}^{-3}$,

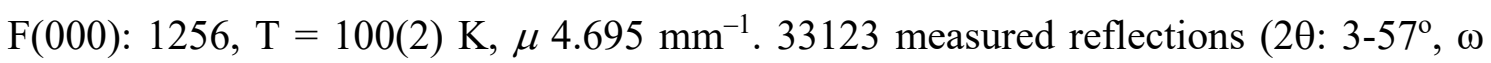
scans $\left.0.3^{\circ}\right), 7506$ unique $\left(R_{\text {int }}=0.1137\right)$; min./max. transm. Factors $0.637 / 0.862$. Final agreement factors were $\mathrm{R}^{1}=0.0221(6710$ observed reflections, $\mathrm{I}>2 \sigma(\mathrm{I}))$ and $\mathrm{wR}^{2}=$ 
0.0513; data/restraints/parameters 7506/9/277; GoF = 1.076. Largest peak and hole 1.670 (close to osmiun atoms) and $-0.858 \mathrm{e} / \AA^{3}$.

Computational details: All calculations in the mechanistic studies were performed at the DFT level using the B3LYP functional ${ }^{4}$ supplemented with the Grimme's dispersion correction D3 ${ }^{5}$ including an ultrafine integration grid, as implemented in Gaussian09. ${ }^{6}$ Os atom was described by means of an effective core potential SDD for the inner electron ${ }^{7}$ and its associated double- $\zeta$ basis set for the outer ones, complemented with a set of $\mathrm{f}-$ polarization functions. ${ }^{8}$ The $6-31 \mathrm{G}^{* *}$ basis set was used for the $\mathrm{H}, \mathrm{C}, \mathrm{N}, \mathrm{O}$, and $\mathrm{P}$ atoms. ${ }^{9}$ All geometries were fully optimized in THF $(\varepsilon=7.58)$ solvent using the continuum SMD model. ${ }^{10}$ Transition states were identified by having one imaginary frequency in the Hessian matrix. It was confirmed that transition states connect with the corresponding intermediates by means of application of an eigenvector corresponding to the imaginary frequency and subsequent optimization of the resulting structures. Gibbs energies were computed at $298.15 \mathrm{~K}$ and 1 atmosphere. All values collected in schemes and figures correspond to Gibbs energies in toluene in $\mathrm{kcal} \mathrm{mol}^{-1}$.

The Cartesian coordinates for the computed structures can be found in the supplemental file xyz. The file may be opened as a text file to read the coordinates, or opened directly by a molecular modeling program such as Mercury (version 3.3 or later, http://www.ccdc.cam.ac.uk/pages/Home.aspx) for visualization and analysis.

\section{Analytical data of the isolated amides}

O Acetamide: ${ }^{11}{ }^{1} \mathrm{H}$ NMR (300.13 MHz, $\left.\mathrm{CDCl}_{3}, 298 \mathrm{~K}\right): \delta 5.49$ (br, 2H, NH 2 ), $2.04\left(\mathrm{~s}, 3 \mathrm{H}, \mathrm{CH}_{3}\right) .{ }^{13} \mathrm{C}\left\{{ }^{1} \mathrm{H}\right\}$ APT NMR $\left(75.48 \mathrm{MHz}, \mathrm{CDCl}_{3}, 298 \mathrm{~K}\right): \delta 172.4$ (CO), $22.6\left(\mathrm{CH}_{3}\right)$. IR (ATR, $\left.\mathrm{cm}^{-1}\right): v(\mathrm{~N}-\mathrm{H}) 3313(\mathrm{~s}), 3185$ (s); v(CO) 1924 (s).

O Propionamide: ${ }^{12}{ }^{1} \mathrm{H}$ NMR (300.13 MHz, $\left.\mathrm{CDCl}_{3}, 298 \mathrm{~K}\right): \delta 5.44$ (br, $2 \mathrm{H}$, $\left.\|_{\mathrm{NH}_{2}} \mathrm{NH}_{2}\right), 2.28\left(\mathrm{q},{ }^{3} J_{\mathrm{H}-\mathrm{H}}=7.6,2 \mathrm{H}, \mathrm{CH}_{2}\right), 1.19\left(\mathrm{t},{ }^{3} J_{\mathrm{H}-\mathrm{H}}=7.6,3 \mathrm{H}, \mathrm{CH}_{3}\right) \cdot{ }^{13} \mathrm{C}\left\{{ }^{1} \mathrm{H}\right\}$ APT NMR (75.48 MHz, $\left.\mathrm{CDCl}_{3}, 298 \mathrm{~K}\right): \delta 176.0(\mathrm{CO}), 28.9\left(\mathrm{CH}_{2} \mathrm{CO}\right), 9.6\left(\mathrm{CH}_{3}\right)$. IR $\left(\mathrm{ATR}, \mathrm{cm}^{-1}\right): v(\mathrm{~N}-\mathrm{H}) 3320(\mathrm{~s}), 3169$ (s); v(CO) 1893 (s).

O Hexanamide: ${ }^{13}{ }^{1} \mathrm{H} \mathrm{NMR}\left(300.13 \mathrm{MHz}, \mathrm{CDCl}_{3}, 298 \mathrm{~K}\right): \delta 5.57$ (br, $\left.2 \mathrm{H}, \mathrm{NH}_{2}\right), 2.23\left(\mathrm{t},{ }^{3} \mathrm{~J}_{\mathrm{H}-\mathrm{H}}=7.6,2 \mathrm{H}, \mathrm{CH}_{2} \mathrm{CO}\right), 1.65\left(\mathrm{~m}, 2 \mathrm{H}, \mathrm{CH}_{2}\right)$, $1.33\left(\mathrm{~m}, 4 \mathrm{H}, \mathrm{CH}_{2} \mathrm{CH}_{2}\right), 0.91\left(\mathrm{~m}, 3 \mathrm{H}, \mathrm{CH}_{3}\right) .{ }^{13} \mathrm{C}\left\{{ }^{1} \mathrm{H}\right\}$ APT NMR $\left(75.48 \mathrm{MHz}, \mathrm{CDCl}_{3}, 298\right.$ 
$\mathrm{K}): \delta 175.7(\mathrm{CO}), 35.9,31.4,25.2,22.4\left(\right.$ all CH$\left._{2}\right), 13.9\left(\mathrm{CH}_{3}\right)$. IR $\left(\mathrm{ATR}, \mathrm{cm}^{-1}\right): v(\mathrm{~N}-\mathrm{H})$ 3356 (s), 3178 (s); v(CO) 1594 (s)

2-Methylpropionamide: ${ }^{14}{ }^{1} \mathrm{H} \mathrm{NMR}\left(400.16 \mathrm{MHz}, \mathrm{CDCl}_{3}, 298 \mathrm{~K}\right): \delta 5.27$ (br, 2H, NH 2$), 2.28$ (hept, $\left.{ }^{3} J_{\mathrm{H}-\mathrm{H}}=6.9,1 \mathrm{H}, \mathrm{CH}\right), 1.03\left(\mathrm{~d},{ }^{3} J_{\mathrm{H}-\mathrm{H}}=6.9,6 \mathrm{H}\right.$, $\left.\mathrm{CH}_{3}\right) .{ }^{13} \mathrm{C}\left\{{ }^{1} \mathrm{H}\right\}$ APT NMR $\left(75.48 \mathrm{MHz}, \mathrm{CDCl}_{3}, 298 \mathrm{~K}\right): \delta 179.5(\mathrm{CO}), 35.0$ (CHCO), $19.6\left(\mathrm{CH}_{3}\right)$. IR (ATR, $\left.\mathrm{cm}^{-1}\right): v(\mathrm{~N}-\mathrm{H}) 3346$ (s), 3169 (s); v(CO) 1634 (s).<smiles>NC(=O)C1CCCCC1</smiles>

Ciclohexanecarboxamide: ${ }^{15}{ }^{1} \mathrm{H}$ NMR (400.16 MHz, $\left.\mathrm{CDCl}_{3}, 298 \mathrm{~K}\right): \delta$ $5.48\left(\mathrm{br}, 2 \mathrm{H}, \mathrm{NH}_{2}\right), 2.16\left(\mathrm{tt},{ }^{3} \mathrm{~J}_{\mathrm{H}-\mathrm{H}}=11.7,{ }^{3} \mathrm{~J}_{\mathrm{H}-\mathrm{H}}=3.5 \mathrm{~Hz}, 1 \mathrm{H}, \mathrm{COCH}\right)$, $1.92\left(\mathrm{~m}, 2 \mathrm{H}, \mathrm{CH}_{2}\right), 1.81\left(\mathrm{~m}, 2 \mathrm{H}, \mathrm{CH}_{2}\right), 1.70\left(\mathrm{~m}, 1 \mathrm{H}, \mathrm{CH}_{2}\right), 1.44(\mathrm{~m}, 2 \mathrm{H}$, $\left.\mathrm{CH}_{2}\right), 1.29\left(\mathrm{~m}, 3 \mathrm{H}, \mathrm{CH}_{2}\right) .{ }^{13} \mathrm{C}\left\{{ }^{1} \mathrm{H}\right\}$ APT NMR (75.48 MHz, $\left.\mathrm{CDCl}_{3}, 298 \mathrm{~K}\right): \delta 178.7(\mathrm{CO})$, 44.8 (CHCO), 29.7, 25.7, $25.7\left(\right.$ all $\left.\mathrm{CH}_{2}\right)$. IR (ATR, $\left.\mathrm{cm}^{-1}\right): v(\mathrm{~N}-\mathrm{H}) 3333$ (s), 3156 (s); $v(\mathrm{CO}) 1633$ (s).

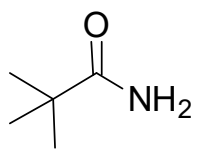

Pivalamide: ${ }^{16}{ }^{1} \mathrm{H}$ NMR (400.16 MHz, $\left.\mathrm{CDCl}_{3}, 298 \mathrm{~K}\right): \delta 5.48(\mathrm{br}, 2 \mathrm{H}$, $\left.\mathrm{NH}_{2}\right), 1.25\left(\mathrm{~s}, 9 \mathrm{H}, \mathrm{CH}_{3}\right) .{ }^{13} \mathrm{C}\left\{{ }^{1} \mathrm{H}\right\}$ APT NMR (75.48 MHz, $\left.\mathrm{CDCl}_{3}, 298 \mathrm{~K}\right)$ : $\delta 181.3(\mathrm{CO}), 38.6\left(\mathrm{C}_{\mathrm{q}} \mathrm{CO}\right), 27.6\left(\mathrm{CH}_{3}\right)$. IR $\left(\mathrm{ATR}, \mathrm{cm}^{-1}\right): v(\mathrm{~N}-\mathrm{H}) 3392(\mathrm{~s})$, $3194(\mathrm{~s}) ; v(\mathrm{CO}) 1621(\mathrm{~s})$.

$\begin{array}{ll}\mathrm{O} \mathrm{MeO}_{\mathrm{NH}_{2}} & \text { 2-Methoxyacetamide: }{ }^{17}{ }^{1} \mathrm{H} \mathrm{NMR}\left(300.13 \mathrm{MHz}, \mathrm{CDCl}_{3}, 2 \mathrm{H}, \mathrm{NH}_{2}\right), 3.92\left(\mathrm{~s}, 2 \mathrm{H}, \mathrm{CH}_{2}\right), 3.45\left(\mathrm{~s}, 3 \mathrm{H}, \mathrm{OCH}_{3}\right) .{ }^{13} \mathrm{C}\left\{{ }^{1} \mathrm{H}\right\} \text { APT }\end{array}$ NMR (75.48 MHz, $\left.\mathrm{CDCl}_{3}, 298 \mathrm{~K}\right): \delta 172.5(\mathrm{CO}), 71.8\left(\mathrm{CH}_{2}\right), 59.2\left(\mathrm{OCH}_{3}\right)$. IR (ATR, $\left.\mathrm{cm}^{-1}\right): v(\mathrm{~N}-\mathrm{H}) 3375(\mathrm{~s}), 3185(\mathrm{~s}) ; v(\mathrm{CO}) 1652(\mathrm{~s})$.<smiles>NC(=O)CCC(=O)c1ccccc1</smiles>

4-Oxo-4-phenylbutanamide: ${ }^{18}{ }^{1} \mathrm{H} \mathrm{NMR}\left(300.13 \mathrm{MHz}, \mathrm{CDCl}_{3}\right.$, $298 \mathrm{~K}): \delta 7.99$ (m, 2H, CH Ph), 7.57 (m, 1H, CH Ph), 7.47 (m, $2 \mathrm{H}, \mathrm{CH} \mathrm{Ph}), 5.61\left(\mathrm{br}, 2 \mathrm{H}, \mathrm{NH}_{2}\right), 3.38\left(\mathrm{t},{ }^{3} \mathrm{~J}_{\mathrm{H}-\mathrm{H}}=6.5,2 \mathrm{H}, \mathrm{CH}_{2}\right)$, $2.68\left(\mathrm{t},{ }^{3} \mathrm{~J}_{\mathrm{H}-\mathrm{H}}=6.5,2 \mathrm{H}, \mathrm{CH}_{2}\right) \cdot{ }^{13} \mathrm{C}\left\{{ }^{1} \mathrm{H}\right\}$ APT NMR (75.48 MHz, $\left.\mathrm{CDCl}_{3}, 298 \mathrm{~K}\right): \delta 193.3$ $(\mathrm{COPh}), 168.9\left(\mathrm{CONH}_{2}\right), 130.9\left(\mathrm{C}_{\mathrm{q}} \mathrm{Ph}\right), 127.8,123.1,122.6($ all $\mathrm{CH} \mathrm{Ph}), 28.4\left(\mathrm{CH}_{2}\right)$, $23.9\left(\mathrm{CH}_{2}\right)$. IR (ATR, $\left.\mathrm{cm}^{-1}\right): v(\mathrm{~N}-\mathrm{H}) 3403$ (s), 3205 (s); v(CO) 1683 (s), 1656 (s).

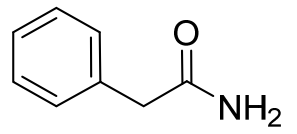

2-Phenylacetamide: ${ }^{15} \mathrm{H} \mathrm{NMR}\left(400.16 \mathrm{MHz}, \mathrm{CDCl}_{3}, 298 \mathrm{~K}\right): \delta 7.29$ (m, 3H, CH Ph), 7.20 (m, 2H, CH Ph), 5.62 (br, 2H, NH ), 3.50 (s, $\left.2 \mathrm{H}, \mathrm{CH}_{2}\right) \cdot{ }^{13} \mathrm{C}\left\{{ }^{1} \mathrm{H}\right\}$ APT NMR (75.48 MHz, $\left.\mathrm{CDCl}_{3}, 298 \mathrm{~K}\right): \delta 173.7$ (CO), $134.9\left(\mathrm{C}_{\mathrm{q}} \mathrm{Ph}\right), 129.4,129.0,127.4$ (all $\left.\mathrm{CH} \mathrm{Ph}\right), 43.3\left(\mathrm{CH}_{2} \mathrm{CO}\right)$. IR (ATR, $\left.\mathrm{cm}^{-1}\right)$ : $v(\mathrm{~N}-\mathrm{H}) 3349$ (s), $3162(\mathrm{~s}) ; v(\mathrm{CO}) 1633$ (s). 
$\overbrace{\mathrm{NH}_{2}}^{\mathrm{O}}$

3-Phenylpropanamide: ${ }^{19} \mathrm{H}$ NMR (300.13 MHz, $\left.\mathrm{CDCl}_{3}, 298 \mathrm{~K}\right)$ :

$\delta 7.31(\mathrm{~m}, 3 \mathrm{H}, \mathrm{CH} \mathrm{Ph}), 7.21(\mathrm{~m}, 2 \mathrm{H}, \mathrm{CH} \mathrm{Ph}), 5.55$ (br, 2H, $\left.\mathrm{NH}_{2}\right)$,

$2.99\left(\mathrm{t},{ }^{3} J_{\mathrm{H}-\mathrm{H}}=8.0,2 \mathrm{H}, \mathrm{CH}_{2} \mathrm{CO}\right), 2.55\left(\mathrm{t},{ }^{3} \mathrm{~J}_{\mathrm{H}-\mathrm{H}}=8.1,2 \mathrm{H}, \mathrm{CH}_{2} \mathrm{Ph}\right)$.

${ }^{13} \mathrm{C}\left\{{ }^{1} \mathrm{H}\right\}$ APT NMR (75.48 MHz, $\left.\mathrm{CDCl}_{3}, 298 \mathrm{~K}\right): \delta 174.5(\mathrm{CO}), 140.7\left(\mathrm{C}_{\mathrm{q}} \mathrm{Ph}\right), 128.6$, 128.3, 126.3 (all CH Ph), $37.5\left(\mathrm{CH}_{2} \mathrm{CO}\right), 31.4\left(\mathrm{CH}_{2} \mathrm{Ph}\right)$. IR (ATR, $\left.\mathrm{cm}^{-1}\right): v(\mathrm{~N}-\mathrm{H}) 3391$ (s), $3180(\mathrm{~s}) ; v(\mathrm{CO}) 1650(\mathrm{~s})$.

$\mathrm{O} \quad$ 2-(p-tolyl)acetamide: ${ }^{20}{ }^{1} \mathrm{H} \mathrm{NMR}\left(400.16 \mathrm{MHz}, \mathrm{CDCl}_{3}, 298 \mathrm{~K}\right): \delta$ 7.09 (m, 4H, CH Ar), 5.44 (br, 2H, NH ), 3.47 (s, 2H, $\mathrm{CH}_{2} \mathrm{CO}$ ), 2.27 (s, 3H, CH3). $\left.{ }^{13} \mathrm{C}^{1}{ }^{1} \mathrm{H}\right\}$ APT NMR (75.48 MHz, $\left.\mathrm{CDCl}_{3}, 298 \mathrm{~K}\right): \delta 173.9(\mathrm{CO}), 137.2\left(\mathrm{C}_{\mathrm{q}}\right.$ Ar), 131.8 ( $\left.\mathrm{C}_{\mathrm{q}} \mathrm{Ar}\right), 129.8,129.3$ (both $\left.\mathrm{CH} \mathrm{Ar}\right), 49.2\left(\mathrm{CH}_{2} \mathrm{CO}\right), 21.1\left(\mathrm{CH}_{3}\right)$. IR (ATR, cm ${ }^{-}$ $\left.{ }^{1}\right): v(\mathrm{~N}-\mathrm{H}) 3346(\mathrm{~s}), 3161(\mathrm{~s}) ; v(\mathrm{CO}) 1630(\mathrm{~s})$<smiles>COc1ccc(CC(N)=O)cc1</smiles>

2-(4-Methoxyphenyl)acetamide: ${ }^{21}{ }^{1} \mathrm{H}$ NMR (300.13 MHz, $\left.\mathrm{CDCl}_{3}, 298 \mathrm{~K}\right): \delta 7.22(\mathrm{~m}, 2 \mathrm{H}, \mathrm{CH} \mathrm{Ar}), 6.92$ (m, 2H, CH Ar), 5.44 (br, $\left.2 \mathrm{H}, \mathrm{NH}_{2}\right), 3.83\left(\mathrm{~s}, 3 \mathrm{H}, \mathrm{OCH}_{3}\right), 3.55\left(\mathrm{~s}, 2 \mathrm{H}, \mathrm{CH}_{2} \mathrm{CO}\right)$. ${ }^{13} \mathrm{C}\left\{{ }^{1} \mathrm{H}\right\}$ APT NMR (75.48 MHz, $\left.\mathrm{CDCl}_{3}, 298 \mathrm{~K}\right): \delta 173.9(\mathrm{CO}), 137.3\left(\mathrm{C}_{\mathrm{q}} \mathrm{Ar}\right), 130.5(\mathrm{CH}$ Ar), $126.9\left(\mathrm{C}_{\mathrm{q}} \mathrm{Ar}\right), 114.5(\mathrm{CH} \mathrm{Ar}), 55.3\left(\mathrm{OCH}_{3}\right), 42.4\left(\mathrm{CH}_{2} \mathrm{CO}\right)$. IR (ATR, cm $\left.{ }^{-1}\right): v(\mathrm{~N}-$ H) $3345(\mathrm{~s}), 3158(\mathrm{~s}) ; v(\mathrm{CO}) 1634(\mathrm{~s})$.<smiles>NC(=O)Cc1ccc(Br)cc1</smiles>

2-(4-Bromophenyl)acetamide: ${ }^{22} \quad{ }^{1} \mathrm{H} \quad \mathrm{NMR} \quad(300.13 \mathrm{MHz}$, $\mathrm{CDCl}_{3}, 298 \mathrm{~K}$ ): $\delta 7.51(\mathrm{~m}, 2 \mathrm{H}, \mathrm{CH} \mathrm{Ar}), 7.19(\mathrm{~m}, 2 \mathrm{H}, \mathrm{CH} \mathrm{Ar}), 5.44$ (br, 2H, $\left.\mathrm{NH}_{2}\right), 3.56\left(\mathrm{~s}, 2 \mathrm{H}, \mathrm{CH}_{2} \mathrm{CO}\right) .{ }^{13} \mathrm{C}\left\{{ }^{1} \mathrm{H}\right\}$ APT NMR $(75.48$ $\left.\mathrm{MHz}, \mathrm{CDCl}_{3}, 298 \mathrm{~K}\right): \delta 172.5$ (CO), 133.7 (C $\mathrm{C}$ Ar), 132.1, 131.1 (both $\mathrm{CH}$ Ar), 121.5 $\left(\mathrm{BrC}_{\mathrm{q}} \mathrm{Ar}\right), 42.5\left(\mathrm{CH}_{2} \mathrm{CO}\right)$. IR (ATR, $\left.\mathrm{cm}^{-1}\right): v(\mathrm{~N}-\mathrm{H}) 3406(\mathrm{~s}) ; v(\mathrm{CO}) 1651(\mathrm{~s})$<smiles>NC(=O)Cc1ccc(C(F)(F)F)cc1</smiles>

2-(4-Trifluorophenyl)acetamide: ${ }^{22}{ }^{1} \mathrm{H}$ NMR $(300.13 \mathrm{MHz}$, $\left.\mathrm{CDCl}_{3}, 298 \mathrm{~K}\right): \delta 7.64$ (m, 2H, CH Ar), 7.44 (m, 2H, CH Ar), 5.51 (br, 2H, NH$), 3.66$ (s, 1H, CHCO). ${ }^{19} \mathrm{~F} \mathrm{NMR} \mathrm{(376.49}$ $\left.\mathrm{MHz}, \mathrm{CDCl}_{3}, 298 \mathrm{~K}\right): 62.58\left(\mathrm{CF}_{3}\right) .{ }^{13} \mathrm{C}\left\{{ }^{1} \mathrm{H}\right\}$ APT NMR $\left(75.48 \mathrm{MHz}, \mathrm{CDCl}_{3}, 298 \mathrm{~K}\right): \delta$ $172.4(\mathrm{CO}), 138.7$ ( $\left.\mathrm{C}_{\mathrm{q}} \mathrm{Ar}\right), 129.7$ (CH Ar), 125.9 (q, ${ }^{4} J_{\mathrm{F}-\mathrm{H}}=3.8, \mathrm{CH}$ Ar), 122.3 (q, ${ }^{3} J_{\mathrm{F}-\mathrm{H}}$ $\left.=18.9, \mathrm{C}_{\mathrm{q}} \mathrm{Ar}\right), 42.8(\mathrm{CHCO})$. The $\mathrm{CF}_{3}$ resonance was not observed. IR $\left(\mathrm{ATR}, \mathrm{cm}^{-1}\right): v(\mathrm{~N}-$ H) 3354 (s), 3164 (s); v(CO) 1634 (s).

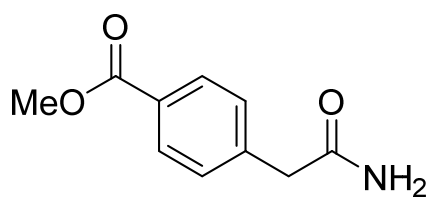

Methyl-4-(2-amino-2-oxoethyl)benzoate: ${ }^{23} \quad{ }^{1} \mathrm{H} \quad$ NMR $\left(300.13 \mathrm{MHz}, \mathrm{CDCl}_{3}, 298 \mathrm{~K}\right): \delta 8.02(\mathrm{~m}, 2 \mathrm{H}, \mathrm{CH}$ Ar), 7.37 (m, 2H, CH Ar), 5.55 (br, 2H, NH 2$), 3.91$ (s, 3H, $\left.\mathrm{OCH}_{3}\right), 3.65$ 
(s, 2H, $\left.\mathrm{CH}_{2} \mathrm{CO}\right) .{ }^{13} \mathrm{C}\left\{{ }^{1} \mathrm{H}\right\}$ APT NMR (75.48 MHz, $\left.\mathrm{CDCl}_{3}, 298 \mathrm{~K}\right): \delta 172.3(\mathrm{CO}), 166.7$ $\left(\mathrm{CO}_{2} \mathrm{Me}\right), 139.9\left(\mathrm{C}_{\mathrm{q}} \mathrm{Ar}\right), 130.2,129.4$ (both $\left.\mathrm{CH} \mathrm{Ar}\right), 129.4\left(\mathrm{C}_{\mathrm{q}} \mathrm{Ar}\right), 52.2\left(\mathrm{OCH}_{3}\right), 43.1$ $\left(\mathrm{CH}_{2} \mathrm{CO}\right)$. IR (ATR, $\left.\mathrm{cm}^{-1}\right): v(\mathrm{~N}-\mathrm{H}) 3386(\mathrm{~s}), 3202$ (s); v(CO) 1720 (s), 1650(s).<smiles>NC(=O)Cc1ccc([N+](=O)[O-])cc1</smiles>
4-Nitrophenylacetamide: ${ }^{24}{ }^{1} \mathrm{H}$ NMR $\left(300.13 \mathrm{MHz}, \mathrm{CDCl}_{3}\right.$, $298 \mathrm{~K}): \delta 8.25$ (m, 2H, CH Ar), 7.51 (m, 2H, CH Ar), 5.43 (br, $\left.2 \mathrm{H}, \mathrm{NH}_{2}\right), 3.71\left(\mathrm{~s}, 2 \mathrm{H}, \mathrm{CH}_{2} \mathrm{CO}\right)$. IR (ATR, $\left.\mathrm{cm}^{-1}\right): v(\mathrm{~N}-\mathrm{H}) 3411$ (s), $3156(\mathrm{~s}) ; v(\mathrm{CO}) 1624(\mathrm{~s}) ; v(\mathrm{NO})$ 1343(s).<smiles>NC(=O)Cc1cccnc1</smiles>

(Pyridin-3-yl)acetamide: ${ }^{15}{ }^{1} \mathrm{H} \mathrm{NMR}\left(300.13 \mathrm{MHz}, \mathrm{CDCl}_{3}, 298 \mathrm{~K}\right)$ : $\delta 8.53$ (br, 2H, CH Py), 7.68 (br, 1H, CH Py), 7.31 (br, 2H, CH Py), 5.89 (br, 2H, NH 2$), 3.59(\mathrm{~s}, 1 \mathrm{H}, \mathrm{CH}) .{ }^{13} \mathrm{C}\left\{{ }^{1} \mathrm{H}\right\}$ APT NMR $(75.48$ $\mathrm{MHz}, \mathrm{CDCl}_{3}, 298 \mathrm{~K}$ ): $\delta 172.3$ (CO), 150.3, 148.6, 136.9 (all CH Py), 130.6 (Cq Py), 123.7 (CH Py), $40.0\left(\mathrm{CH}_{2}\right)$. IR (ATR, $\left.\mathrm{cm}^{-1}\right): v(\mathrm{~N}-\mathrm{H}) 3348$ (s), 3088 (s); v(CO) 1671 (s).<smiles>CC(C(N)=O)c1ccccc1</smiles>

2-Phenylpropanamide: ${ }^{25}{ }^{1} \mathrm{H}$ NMR (300.13 MHz, $\left.\mathrm{CDCl}_{3}, 298 \mathrm{~K}\right): \delta$ 7.39-7.28 (m, 5H, CH Ph), $5.47\left(\mathrm{br}, 2 \mathrm{H}, \mathrm{NH}_{2}\right), 3.61$ (q, ${ }^{3} J_{\mathrm{H}-\mathrm{H}}=7.2$, $1 \mathrm{H}, \mathrm{CHCO}), 1.55\left(\mathrm{~d},{ }^{3} \mathrm{~J}_{\mathrm{H}-\mathrm{H}}=7.2,3 \mathrm{H}, \mathrm{CH}_{3}\right) .{ }^{13} \mathrm{C}\left\{{ }^{1} \mathrm{H}\right\}$ APT NMR (75.48 MHz, $\left.\mathrm{CDCl}_{3}, 298 \mathrm{~K}\right): \delta 176.7$ (CO), $141.3\left(\mathrm{C}_{\mathrm{q}} \mathrm{Ph}\right), 129.0,127.6,127.4$ (all $\mathrm{CH}$ $\mathrm{Ph}), 46.6$ (CHCO), $18.3\left(\mathrm{CH}_{3}\right)$. IR (ATR, $\left.\mathrm{cm}^{-1}\right): v(\mathrm{~N}-\mathrm{H}) 3354$ (s), $3176(\mathrm{~s}) ; v(\mathrm{CO}) 1632$ (s).<smiles>CC(C)Cc1ccc(C(C)C(N)=O)cc1</smiles>

2-(4-Isobutylphenyl)propanamide: ${ }^{26} \quad{ }^{1} \mathrm{H} \quad \mathrm{NMR} \quad(300.13$ $\left.\mathrm{MHz}, \mathrm{CDCl}_{3}, 298 \mathrm{~K}\right): \delta 7.14(\mathrm{~m}, 2 \mathrm{H}, \mathrm{CH} \mathrm{Ar}), 7.05(\mathrm{~m}, 2 \mathrm{H}$, $\mathrm{CH}$ Ar), 5.44 (br, 2H, NH 2$), 3.50$ (q, $\left.{ }^{3} J_{\mathrm{H}-\mathrm{H}}=7.2,1 \mathrm{H}, \mathrm{CHCO}\right)$, $2.38\left(\mathrm{~d},{ }^{3} \mathrm{~J}_{\mathrm{H}-\mathrm{H}}=7.2,3 \mathrm{H}, \mathrm{CH}_{3}\right), 1.77\left(\mathrm{~m}, 1 \mathrm{H}, \mathrm{CH}{ }^{\mathrm{i}} \mathrm{Pr}\right), 1.44\left(\mathrm{~d},{ }^{3} \mathrm{~J}_{\mathrm{H}-\mathrm{H}}=7.2,3 \mathrm{H}, \mathrm{CH}_{3}\right), 0.83$ $\left(\mathrm{d},{ }^{3} \mathrm{~J}_{\mathrm{H}-\mathrm{H}}=6.6,6 \mathrm{H}, \mathrm{CH}_{3}{ }^{\mathrm{i} P r}\right) .{ }^{13} \mathrm{C}\left\{{ }^{1} \mathrm{H}\right\}$ APT NMR (75.48 MHz, $\left.\mathrm{CDCl}_{3}, 298 \mathrm{~K}\right): \delta 177.0$ (CO), 140.9, 138.5 (both $\mathrm{C}_{\mathrm{q}} \mathrm{Ar}$ ), 129.7, 127.3 (both $\mathrm{CH}$ Ar), 46.3 (CHCO), $45.0\left(\mathrm{CH}_{2}\right)$, $30.2(\mathrm{CH}), 22.4,18.3$ (both $\left.\mathrm{CH}_{3}\right)$. IR (ATR, $\left.\mathrm{cm}^{-1}\right): v(\mathrm{~N}-\mathrm{H}) 3346$ (s), $3168(\mathrm{~s}) ; v(\mathrm{CO})$ 1630 (s).<smiles>CC(C(N)=O)c1cccc(C(=O)c2ccccc2)c1</smiles>

2-(3-Benzoylphenyl)propanamide: ${ }^{27}{ }^{1} \mathrm{H}$ NMR (300.13 $\left.\mathrm{MHz}, \mathrm{CDCl}_{3}, 298 \mathrm{~K}\right): \delta 7.78(\mathrm{~m}, 3 \mathrm{H}, \mathrm{CH} \mathrm{Ar}), 7.67(\mathrm{~m}, 1 \mathrm{H}$, $\mathrm{CH}$ Ar), 7.59 (m, 2H, CH Ar), 7.49 (m, 3H, CH Ar), 5.74 (br, $\left.2 \mathrm{H}, \mathrm{NH}_{2}\right), 3.70\left(\mathrm{q},{ }^{3} J_{\mathrm{H}-\mathrm{H}}=7.0,1 \mathrm{H}, \mathrm{CHCO}\right), 1.55\left(\mathrm{~d},{ }^{3} J_{\mathrm{H}-\mathrm{H}}=7.0,3 \mathrm{H}, \mathrm{CH}_{3}\right) .{ }^{13} \mathrm{C}\left\{{ }^{1} \mathrm{H}\right\}$ APT NMR (75.48 MHz, $\left.\mathrm{CDCl}_{3}, 298 \mathrm{~K}\right): \delta 196.5(\mathrm{CO}), 176.0\left(\mathrm{CONH}_{2}\right), 141.8,138.1$, 
$137.4\left(\mathrm{C}_{\mathrm{q}} \mathrm{Ar}\right), 132.6,131.5,130.0,129.2,129.1,128.8,128.4($ all $\mathrm{CH}$ Ar), $46.4(\mathrm{CH})$, $18.5\left(\mathrm{CH}_{3}\right)$. IR (ATR, $\left.\mathrm{cm}^{-1}\right): v(\mathrm{~N}-\mathrm{H}) 3342(\mathrm{~s}), 3190(\mathrm{~s}) ; v(\mathrm{CO}) 1651$ (s).<smiles>NC(=O)C(c1ccccc1)c1ccccc1</smiles>

2,2-Diphenylacetamide: ${ }^{28}{ }^{1} \mathrm{H} \mathrm{NMR}\left(300.13 \mathrm{MHz}, \mathrm{CDCl}_{3}, 298 \mathrm{~K}\right): \delta$

7.39-7.28 (m, 10H, CH Ph), 5.71 (br, 2H, NH 2$), 4.98$ (s, 1H, CH).

${ }^{13} \mathrm{C}\left\{{ }^{1} \mathrm{H}\right\}$ APT NMR (75.48 MHz, $\left.\mathrm{CDCl}_{3}, 298 \mathrm{~K}\right): \delta 174.4(\mathrm{CO}), 139.2$

$\left(\mathrm{C}_{\mathrm{q}} \mathrm{Ph}\right), 128.9,128.8,127.4(\mathrm{CH} \mathrm{Ph}), 58.8(\mathrm{CH}) . \mathrm{IR}\left(\mathrm{ATR}, \mathrm{cm}^{-1}\right)$ :

$v(\mathrm{~N}-\mathrm{H}) 3387(\mathrm{~s}), 3173(\mathrm{~s}) ; v(\mathrm{CO}) 1651(\mathrm{~s})$.

\section{References}

(1) Aracama, M.; Esteruelas, M. A.; Lahoz, F. J.; López, J. A.; Meyer, U.; Oro, L. A.; Werner, H. Synthesis, Reactivity, Molecular Structure, and Catalytic Activity of the Novel Dichlorodihydridoosmium(IV) Complexes $\mathrm{OsH}_{2} \mathrm{Cl}_{2}\left(\mathrm{PR}_{3}\right)_{2}\left(\mathrm{PR}_{3}=\mathrm{P}-i-\mathrm{Pr}_{3}, \mathrm{PMe}-t-\right.$ $\mathrm{Bu}_{2}$ ). Inorg. Chem. 1991, 30, 288-293.

(2) Blessing, R. H. An Empirical Correction for Absorption Anisotropy. Acta Crystallogr. 1995, A51, 33. SADABS: Area-detector absorption correction; BrukerAXS, Madison, WI, 1996.

(3) SHELXL-2016/6. Sheldrick, G. M. A short history of SHELX. Acta Cryst. 2008, A64, 112-122.

(4) (a) Lee, C.; Yang, W.; Parr, R. G. Development of the Colle-Salvetti correlationenergy formula into a functional of the electron density. Phys. Rev. B 1988, 37, 785-789. (b) Becke, A. D. Density-functional thermochemistry .III. The role of exact exchange. $J$. Chem. Phys. 1993, 98, 5648-5652. (c) Stephens, P. J.; Devlin, F. J.; Chabalowski, C. F.; Frisch, M. J. Ab Initio Calculation of Vibrational Absorption and Circular Dichroism Spectra Using Density Functional Force Fields J. Phys. Chem. 1994, 98, 11623-11627.

(5) Grimme, S.; Antony, J.; Ehrlich, S.; Krieg, H. A consistent and accurate ab initio parametrization of density functional dispersion correction (DFT-D) for the 94 elements H-Pu. J. Chem. Phys., 2010, 132, 154104-154123.

(6) Gaussian 09, Revision D.01, Frisch, M. J.; Trucks, G. W.; Schlegel H. B.; Scuseria, G. E.; Robb, M. A.; Cheeseman, J. R.; Scalmani, G.; Barone, V.; Mennucci, B.; Petersson, G. A.; Nakatsuji, H.; Caricato, M.; Li, X.; Hratchian, H. P.; Izmaylov, A. F.; Bloino, J.; Zheng, G.; Sonnenberg, J. L.; Hada, M.; Ehara, M.; Toyota, K.; Fukuda, R.; Hasegawa, J.; Ishida, M.; Nakajima, T.; Honda, Y.; Kitao, O.; Nakai, H.; Vreven, T.; Montgomery, J. A.; Peralta, Jr., J. E.; Ogliaro, F.; Bearpark, M.; Heyd, J. J.; Brothers, E.; Kudin, K. N.; Staroverov, V. N.; Keith, T.; Kobayashi, R.; Normand, J.; Raghavachari, K.; Rendell, A.; Burant, J. C.; Iyengar, S. S.; Tomasi, J.; Cossi, M.; Rega, N.; Millam, J. M.; Klene, M.; Knox, J. E.; Cross, J. B.; Bakken, V.; Adamo, C.; Jaramillo, J.; Gomperts, R.; Stratmann, R. E.; Yazyev, O.; Austin, A. J.; Cammi, R.; Pomelli, C.; Ochterski, J. W.; Martin, R. L.; Morokuma, K.; Zakrzewski, V. G.; Voth, G. A.; Salvador, P.; Dannenberg, J. J.; Dapprich, S.; Daniels, A. D.; Farkas, O.; Foresman, J. B.; Ortiz, J. V.; Cioslowski, J.; Fox, D. J. Gaussian, Inc., Wallingford CT, 2013. 
(7) Andrea, D.; Haeussermann, U. M.; Dolg, M.; Stoll, H.; Preuss, H. Energyadjustedab initio pseudopotentials for the second and third row transition elements Theor. Chim. Acta 1990, 77, 123-141.

(8) Ehlers, A. W.; Bohme, M.; Dapprich, S.; Gobbi, A.; Hollwarth, A.; Jonas, V.; Kohler, K. F.; Stegmann, R.; Veldkamp, A.; Frenking, G. A set of f-polarization functions for pseudo-potential basis sets of the transition metals $\mathrm{SC}-\mathrm{Cu}, \mathrm{Y}-\mathrm{Ag}$ and $\mathrm{La}-\mathrm{Au}$. Chem. Phys. Lett. 1993, 208, 111-114.

(9) (a) Hehre, W. J.; Ditchfield, R.; Pople, J. A. Self-Consistent Molecular Orbital Methods. XII. Further Extensions of Gaussian-Type Basis Sets for Use in Molecular Orbital Studies of Organic Molecules. J. Chem. Phys. 1972, 56, 2257-2261. (b) Francl, M. M.; Pietro, W. J.; Hehre, W. J.; Binkley, J. S.; Gordon, M. S.; DeFrees, D. J.; Pople, J. A. Self-consistent molecular orbital methods. XXIII. A polarization-type basis set for second-row elements. J. Chem. Phys. 1982, 77, 3654-3665.

(10) Marenich, A. V.; Cramer, C. J.; Truhlar, D. G. Universal Solvation Model Based on Solute Electron Density and on a Continuum Model of the Solvent Defined by the Bulk Dielectric Constant and Atomic Surface Tensions J. Phys. Chem. B 2009, 113, 6378-6396.

(11) Ali, M. A.; Punniyamurthy, T. Palladium-Catalyzed One-Pot Conversion of Aldehydes to Amides. Adv. Synth. Catal. 2010, 352, 288-292.

(12) Kuzma, P. C.; Brown, L. E.; Harris, T. M. Generation of the Dianion of $N$ (Trimethylsilyl)acetamide and Reaction of the Dianion with Electrophilic Reagents. $J$. Org. Chem. 1984, 49, 2015-2018.

(13) Page, P. C. B.; Rosenthal, S.; Williams, R. V. A New, One-Pot Synthesis of Primary 2-Alkynamides. Synthesis 1988, 621-623.

(14) Coxon, B.; Fatiadi, A. J.; Sniegoski, L. T.; Hertz, H. S.; Schaffer, R. A Novel Acylative Degradation of Uric Acid. Carbon-13 Nuclear Magnetic Resonance Studies of Uric Acid and Its Degradation Products. J. Org. Chem. 1977, 42, 3132-3140.

(15) Bonne, D.; Dekhane, M.; Zhu, J. Mild Oxidative One-Carbon Homologation of Aldehyde to Amide. J. Am. Chem. Soc. 2005, 127, 6926-6927.

(16) Kaufmann, D.; Bialer, M.; Shimshoni, J. A.; Devor, M.; Yagen, B. Synthesis and Evaluation of Antiallodynic and Anticonvulsant Activity of Novel Amide and Urea Derivatives of Valproic Acid Analogues. J. Med. Chem. 2009, 52, 7236-7248.

(17) Breno, K. L.; Pluth, M. D.; Tyler, D. R. Organometallic Chemistry in Aqueous Solution. Hydration of Nitriles to Amides Catalyzed by a Water-Soluble Molybdocene, $(\mathrm{MeCp})_{2} \mathrm{Mo}(\mathrm{OH})\left(\mathrm{H}_{2} \mathrm{O}\right)^{+}$. Organometallics 2003, 22, 1203-1211.

(18) Kouser, F.; Sharma, V. K.; Rizvi, M.; Sultan, S.; Chalotra, N.; Gupta, V. K.; Nandi, U.; Shah, B. A. Stereoselective synthesis of 3,4-di-substituted mercaptolactones viaphotoredox-catalyzed radical addition of thiophenols. Tetrahedron Lett. 2018, 59, 2161-2166.

(19) Brinchi, L.; Chiavini, L.; Goracci, L.; Di Profio, P.; Germani, R. Efficient Hydrolysis of Nitriles to Amides with Hydroperoxide Anion in Aqueous Surfactant Solutions as Reaction Medium. Lett. Org. Chem. 2009, 6, 175-179.

(20) BIORAD: https://spectrabase.com/spectrum/7S7BfqYTYpz.

(21) Chen, H.; Dai, W.; Chen, Y.; Xu, Q.; Chen, J.; Yu, L.; Zao, Y.; Ye, M.; Pan, Y. Efficient and selective nitrile hydration reactions in water catalyzed by an unexpected 
dimethylsulfinyl anion generated in situ from $\mathrm{CsOH}$ and DMSO. Green Chem. 2014, 16, 2136-2141.

(22) Yoshimura, A.; Middleton, K. R.; Luedtke, M. W.; Zhu, C.; Zhdankin, V. V. Hypervalent Iodine Catalyzed Hofmann Rearrangement of Carboxamides Using Oxone as Terminal Oxidant. J. Org. Chem. 2012, 77, 11399-11404.

(23) Shen, W.; Kunzer, A. A Facile One-Carbon Homologation of Aryl Aldehydes to Amides. Org. Lett. 2002, 4, 1315-1317.

(24) Veisi, H.; Maleki, B.; Hamelian, M.; Ashrafi, S. S. Chemoselective hydration of nitriles to amides using hydrated ionic liquid (IL) tetrabutylammonium hydroxide (TBAH) as a green catalyst. $R S C A d v . \mathbf{2 0 1 5}, 5,6365-6371$.

(25) Liu, C.; He, C.; Shi, W.; Chen, M.; Lei, A. Ni-Catalyzed Mild Arylation of $\alpha-$ Halocarbonyl Compounds with Arylboronic Acids. Org. Lett. 2007, 26, 5601-5604.

(26) García-Álvarez, R.; Francos J.; Crochet, P.; Cadierno, V. Ibuprofenamide: A convenient method of synthesis by catalytic hydration of 2-(4isobutylphenyl)propionitrile in pure aqueous medium. Tetrahedron Lett. 2011, 52, 42184220 .

(27) CAS: 59512-16-2

(28) Kitamura, M.; Miyagawa, S.; Okauchi, T. Synthesis of $\alpha, \alpha$-diarylacetamides from benzyl aryl ketones using 2-azido-1,3-dimethylimidazolinium hexafluorophosphate. Tetrahedron Lett. 2011, 52, 3158-3161. 
${ }^{1} \mathrm{H}$ NMR spectra of the reaction crude of the catalytic nitrile hydrations, ${ }^{1} \mathrm{H},{ }^{13} \mathrm{C}\left\{{ }^{1} \mathrm{H}\right\}$ APT NMR and IR spectra of the amides

${\stackrel{\mathrm{O}}{\mathrm{NH}_{2}}}$
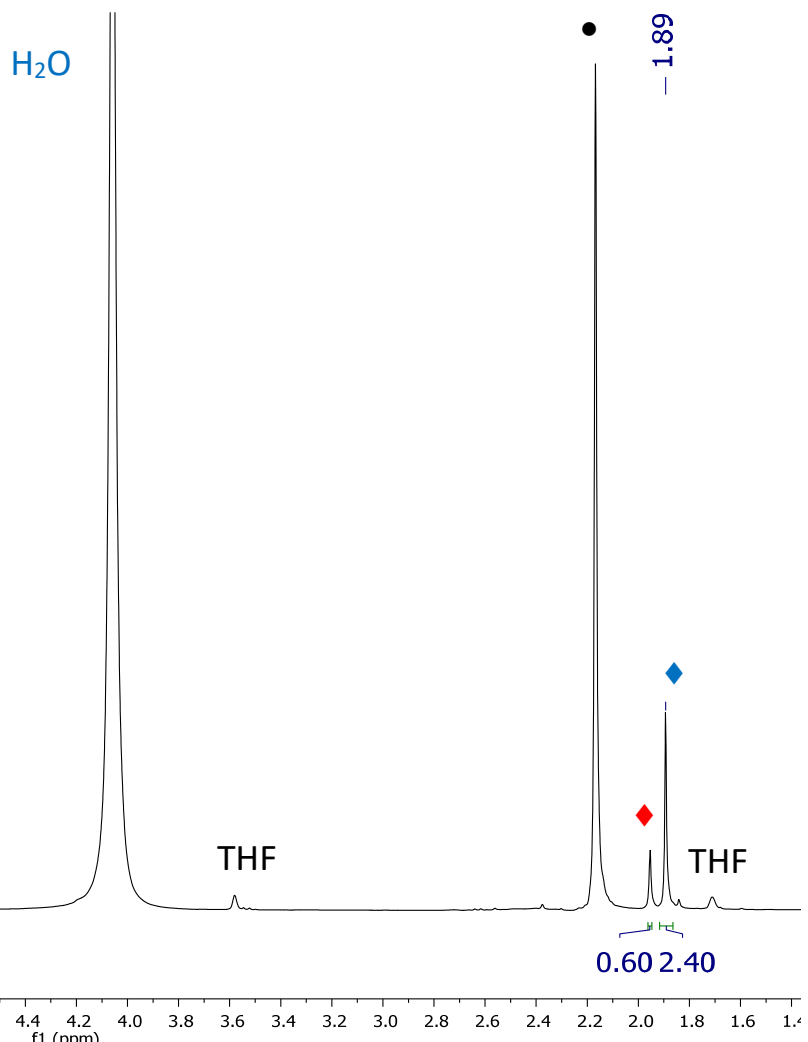

Figure S1. ${ }^{1} \mathrm{H}$ NMR (300.13 MHz, THF- $\left.d_{8}, 298 \mathrm{~K}\right)$ spectrum of the reaction mixture of the hydration of acetonitrile $(\diamond)$ : formation of acetamide $(\diamond)$. $\bullet$ Mesitylene. 
<smiles>CC(N)=O</smiles>

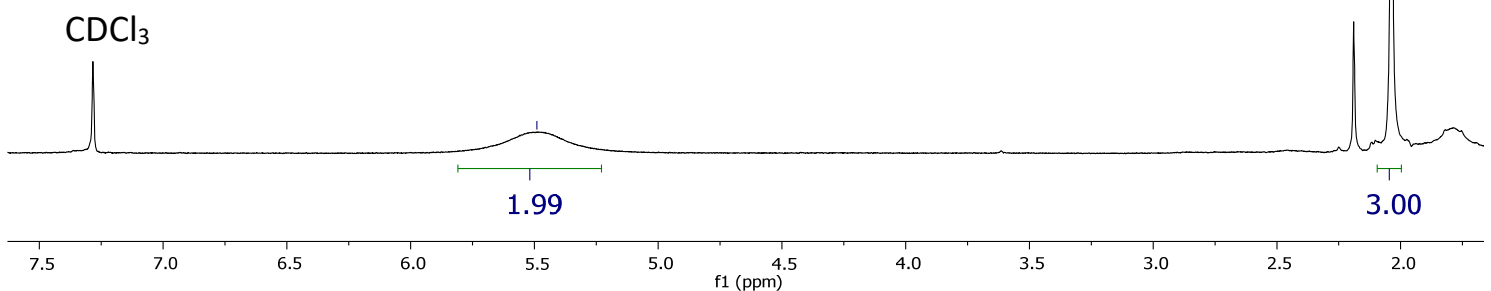

Figure S2. ${ }^{1} \mathrm{H}$ NMR $\left(300.13 \mathrm{MHz}, \mathrm{CDCl}_{3}, 298 \mathrm{~K}\right)$ spectrum of acetamide.

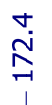<smiles>CC(N)=O</smiles>

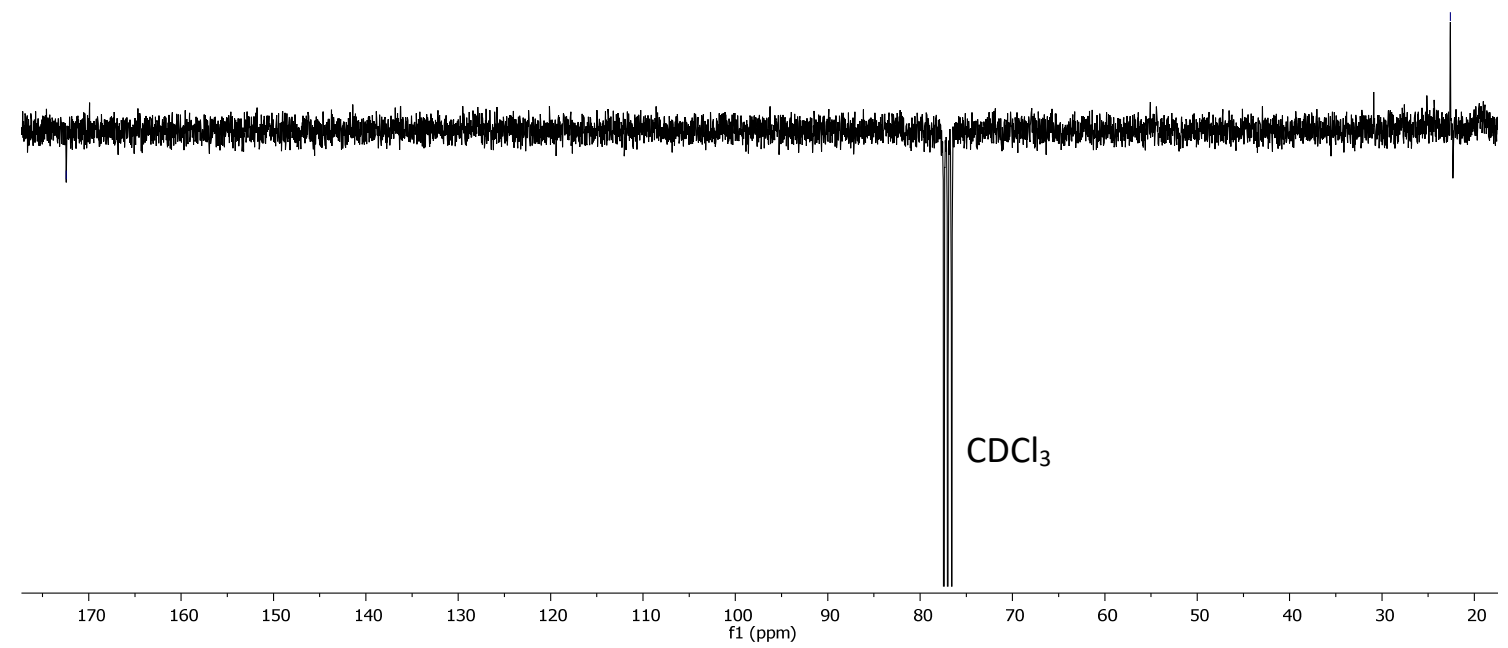

Figure S3. ${ }^{13} \mathrm{C}\left\{{ }^{1} \mathrm{H}\right\}$ APT NMR (75.48 MHz, $\left.\mathrm{CDCl}_{3}, 298 \mathrm{~K}\right)$ spectrum of acetamide. 


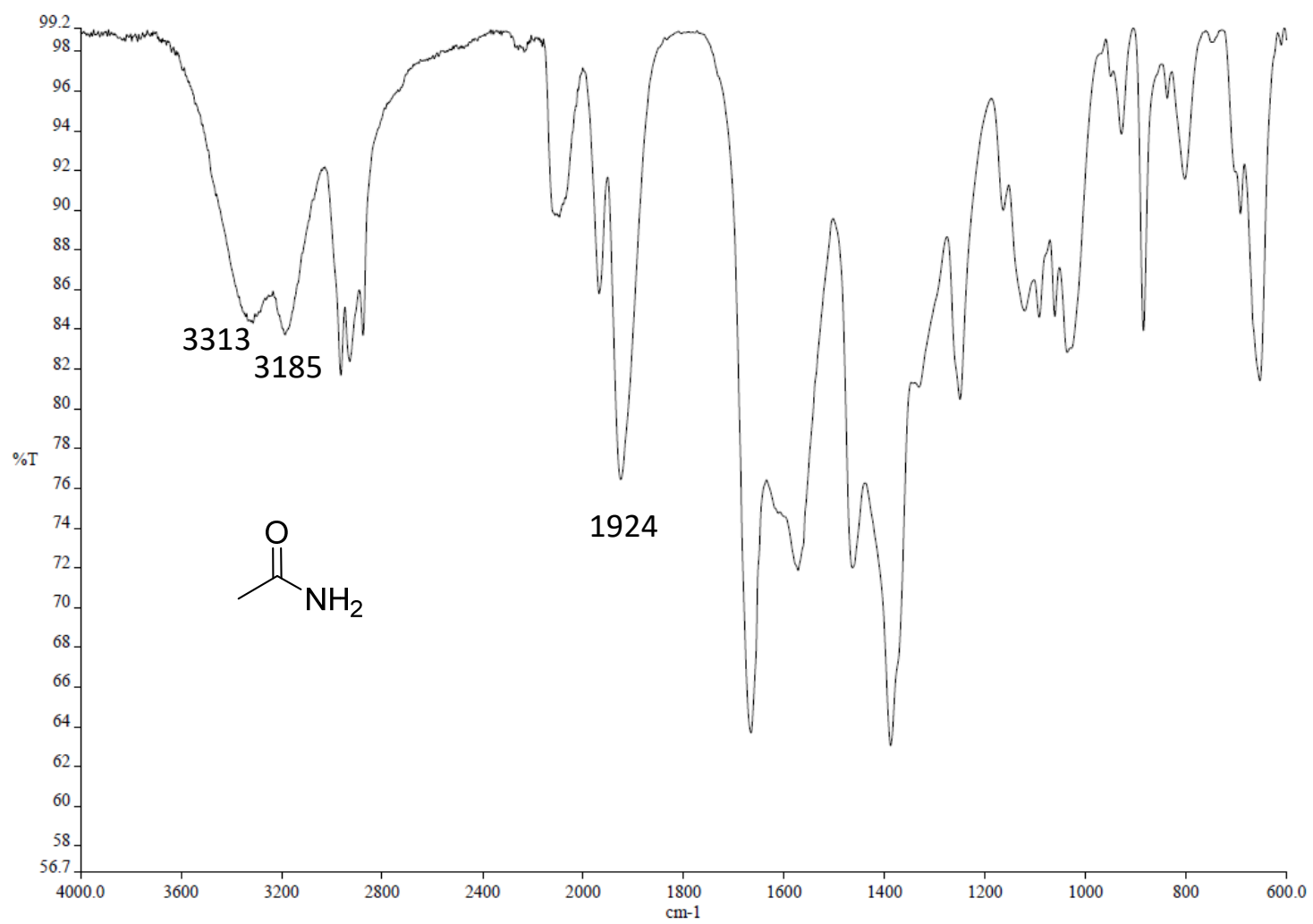

Figure S4. IR ATR spectrum of acetamide.

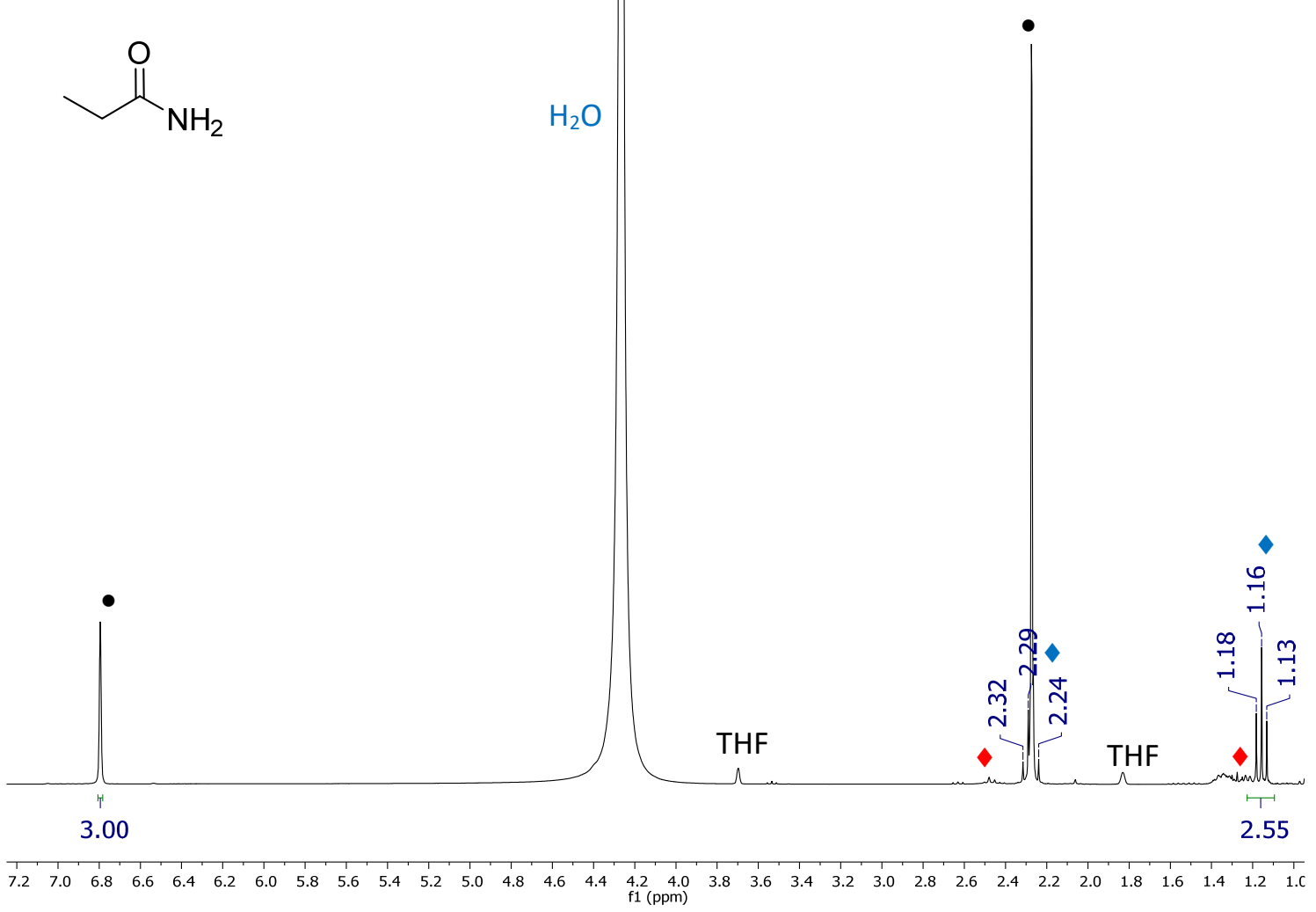

Figure S5. ${ }^{1} \mathrm{H}$ NMR $(300.13 \mathrm{MHz}$, THF-d8, $298 \mathrm{~K})$ spectrum of the reaction mixture of the hydration of propionitrile $(\diamond)$ : formation of propionamide $(\diamond) \cdot \bullet$ Mesitylene. 
<smiles>CCC(N)=O</smiles>

$\mathrm{NH}_{2}$

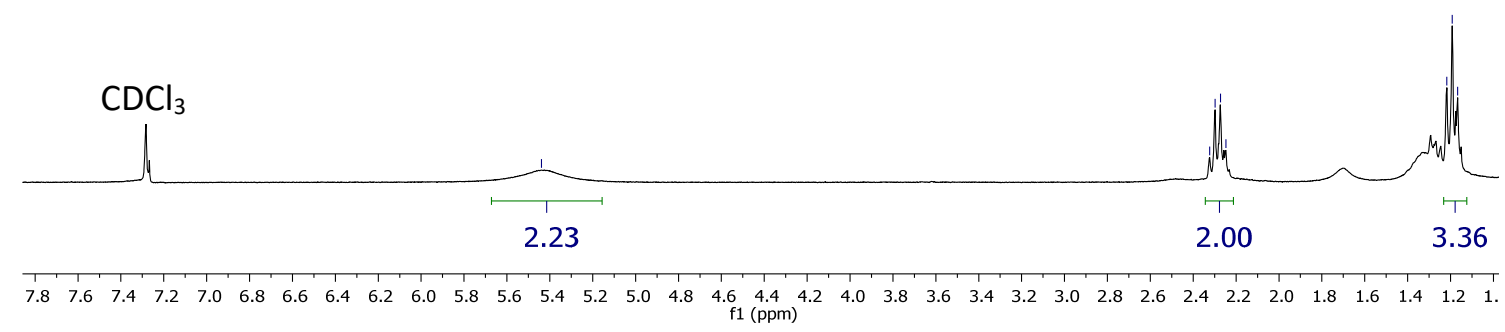

Figure S6. ${ }^{1} \mathrm{H}$ NMR $\left(300.13 \mathrm{MHz}, \mathrm{CDCl}_{3}, 298 \mathrm{~K}\right)$ spectrum of propanamide.

0
$\stackrel{0}{7}$
1<smiles>CCC(N)=O</smiles>

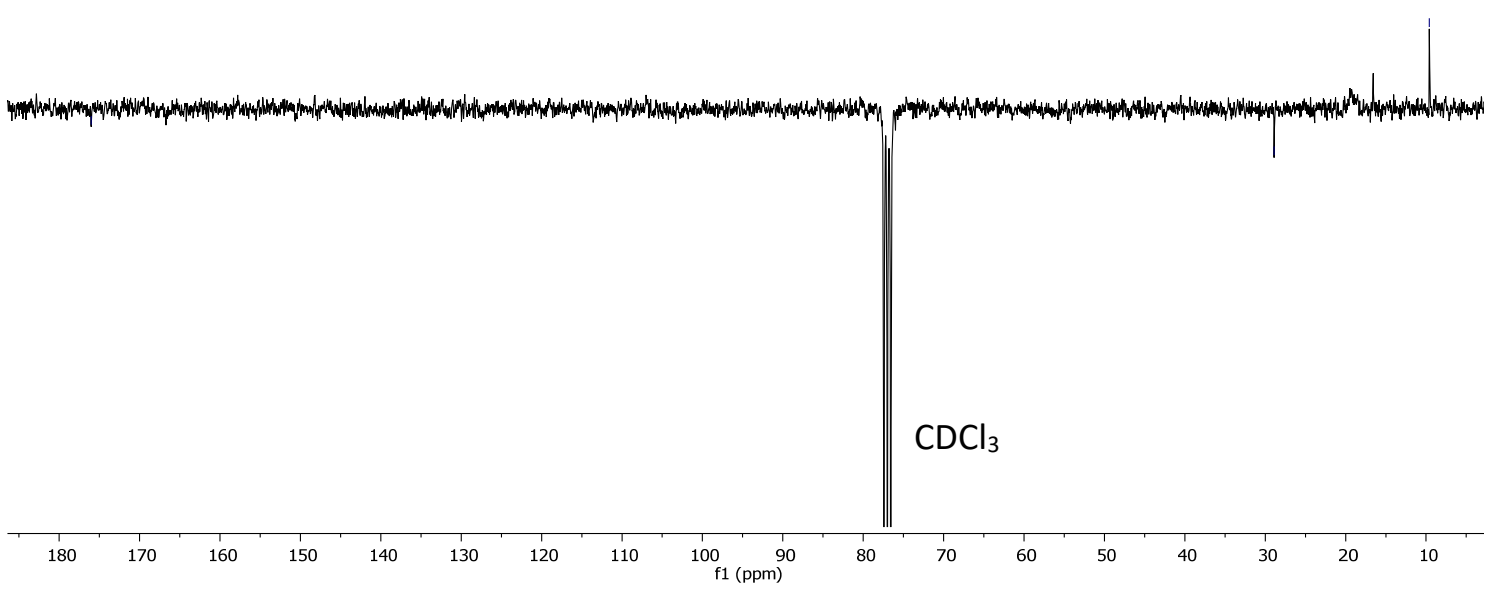

Figure S7. ${ }^{13} \mathrm{C}\left\{{ }^{1} \mathrm{H}\right\}$ APT NMR $\left(75.48 \mathrm{MHz}, \mathrm{CDCl}_{3}, 298 \mathrm{~K}\right)$ spectrum of propanamide. 


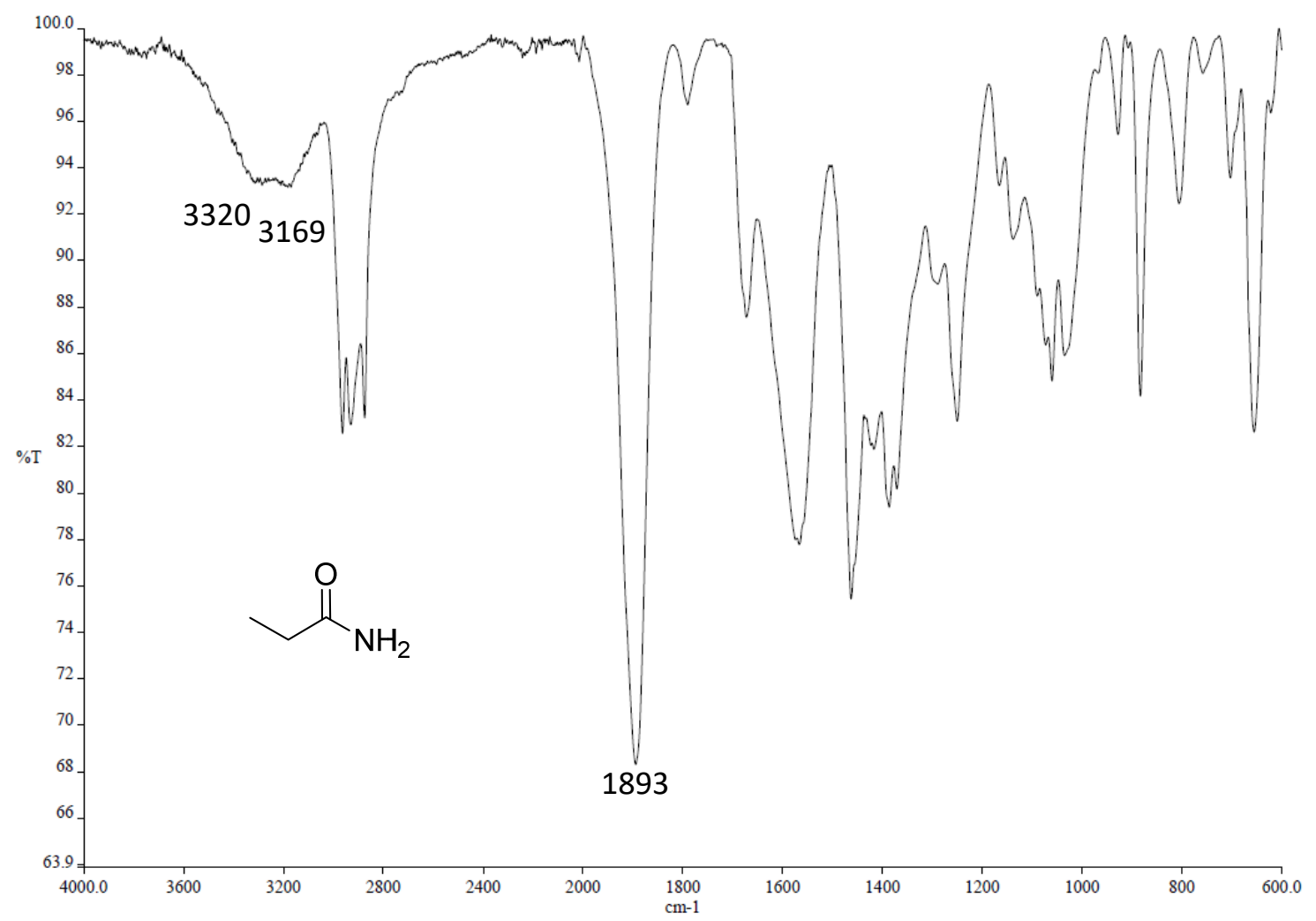

Figure S8. IR ATR spectrum of propanamide.

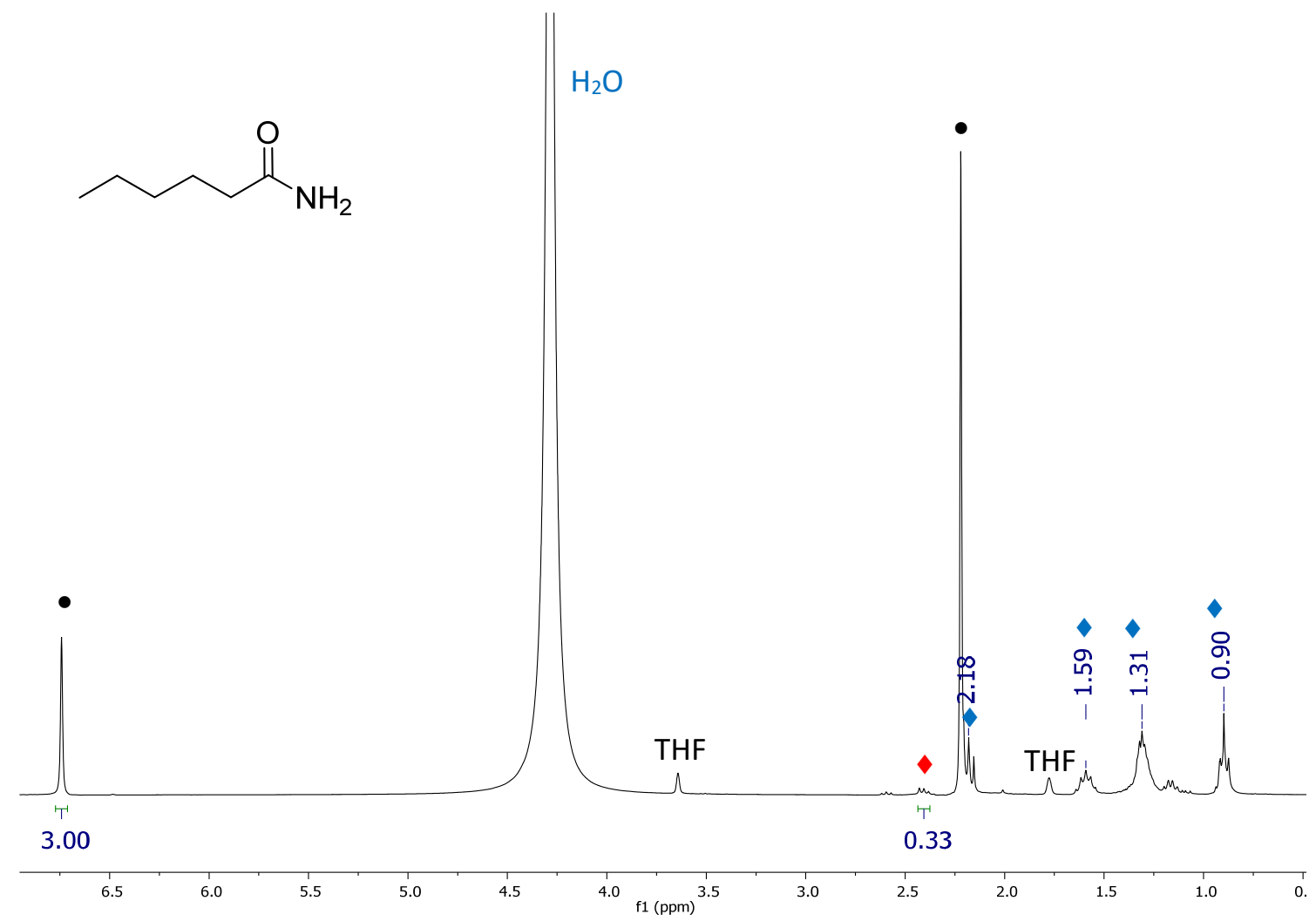

Figure S9. ${ }^{1} \mathrm{H}$ NMR $\left(300.13 \mathrm{MHz}\right.$, THF- $\left.d_{8}, 298 \mathrm{~K}\right)$ spectrum of the reaction mixture of the hydration of hexanenitrile $(\diamond)$ : formation of hexanamide $(\diamond) \cdot \bullet$ Mesitylene. 
<smiles>CCCCCC(N)=O</smiles>

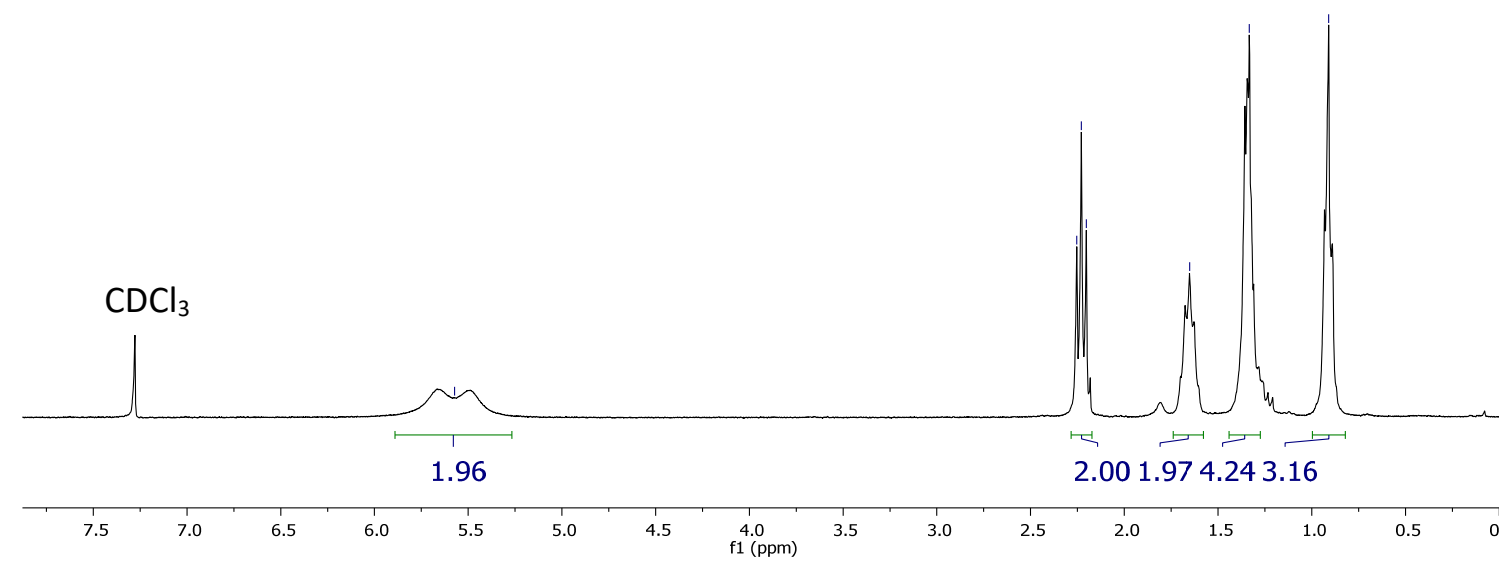

Figure S10. ${ }^{1} \mathrm{H}$ NMR $\left(300.13 \mathrm{MHz}, \mathrm{CDCl}_{3}, 298 \mathrm{~K}\right)$ spectrum of hexanamide.

苫

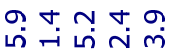<smiles>CCCCCC(N)=O</smiles>

mกำ $\mathrm{NH}_{2}$

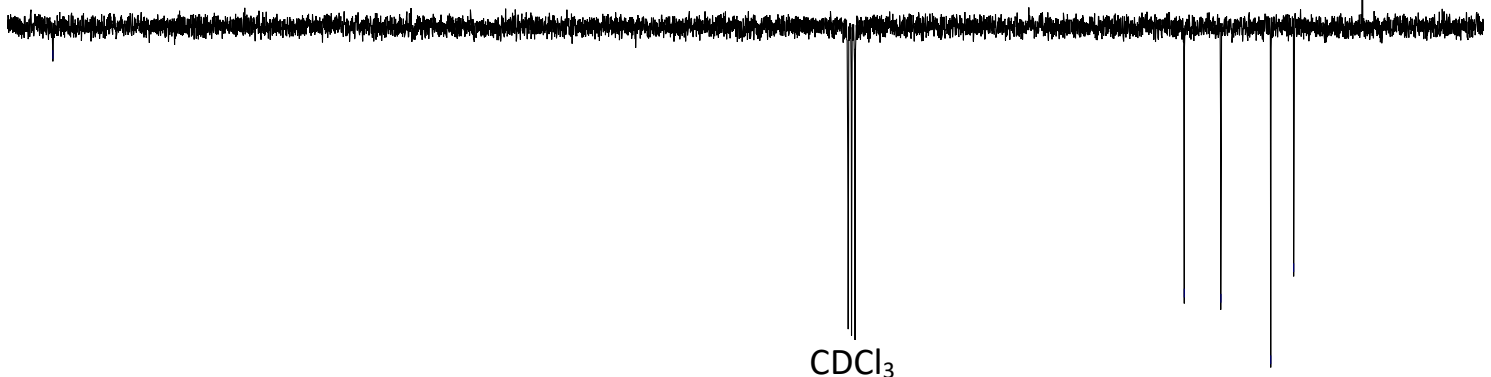

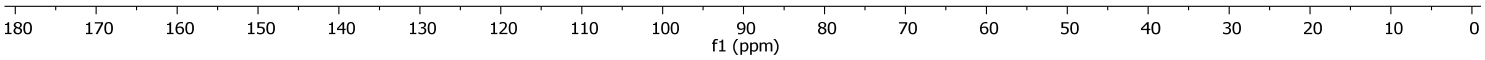

Figure S11. ${ }^{13} \mathrm{C}\left\{{ }^{1} \mathrm{H}\right\}$ APT NMR $\left(75.48 \mathrm{MHz}, \mathrm{CDCl}_{3}, 298 \mathrm{~K}\right)$ spectrum of hexanamide. 


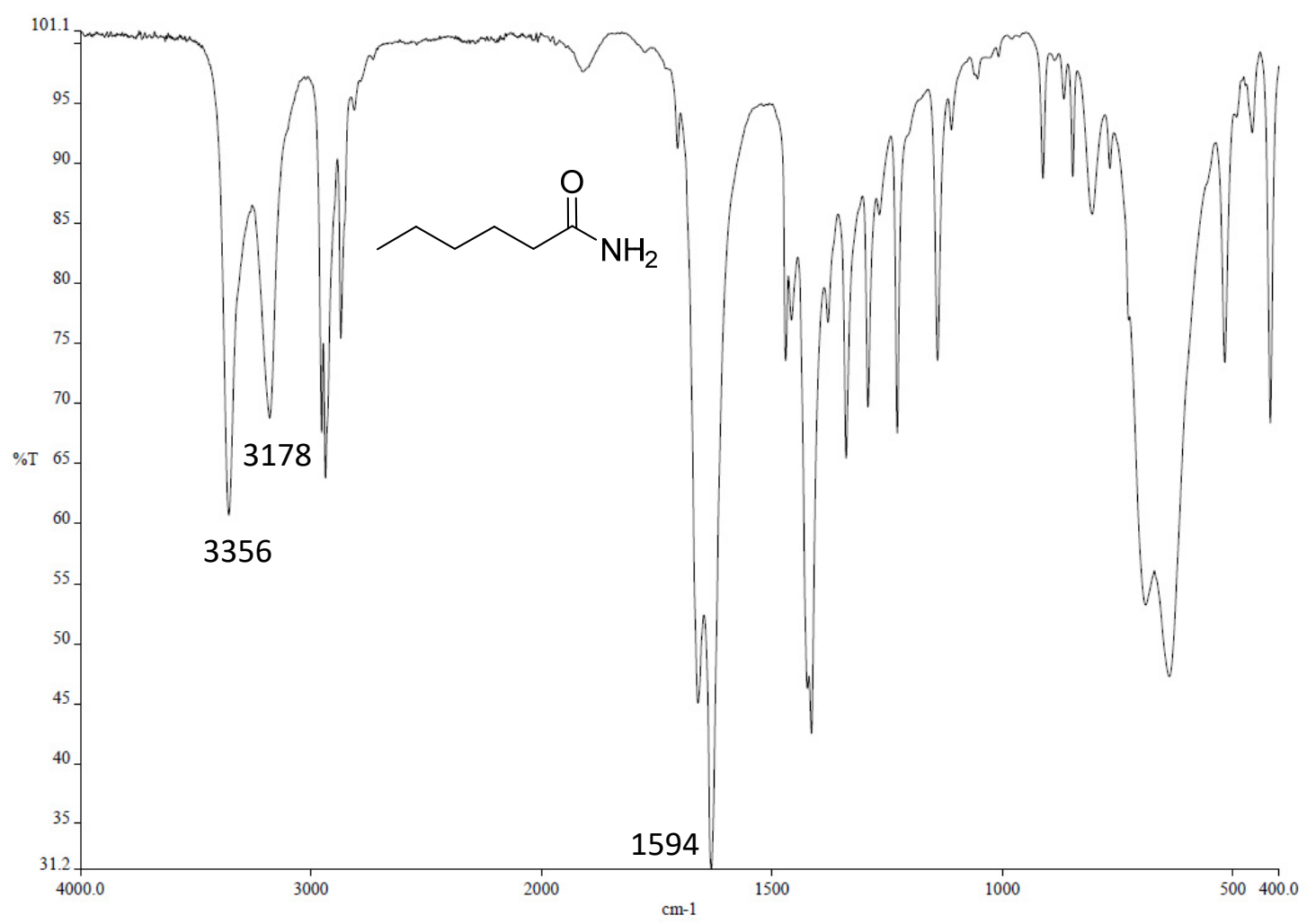

Figure S12. IR ATR spectrum of hexanamide.<smiles>CC(C)C(N)=O</smiles>

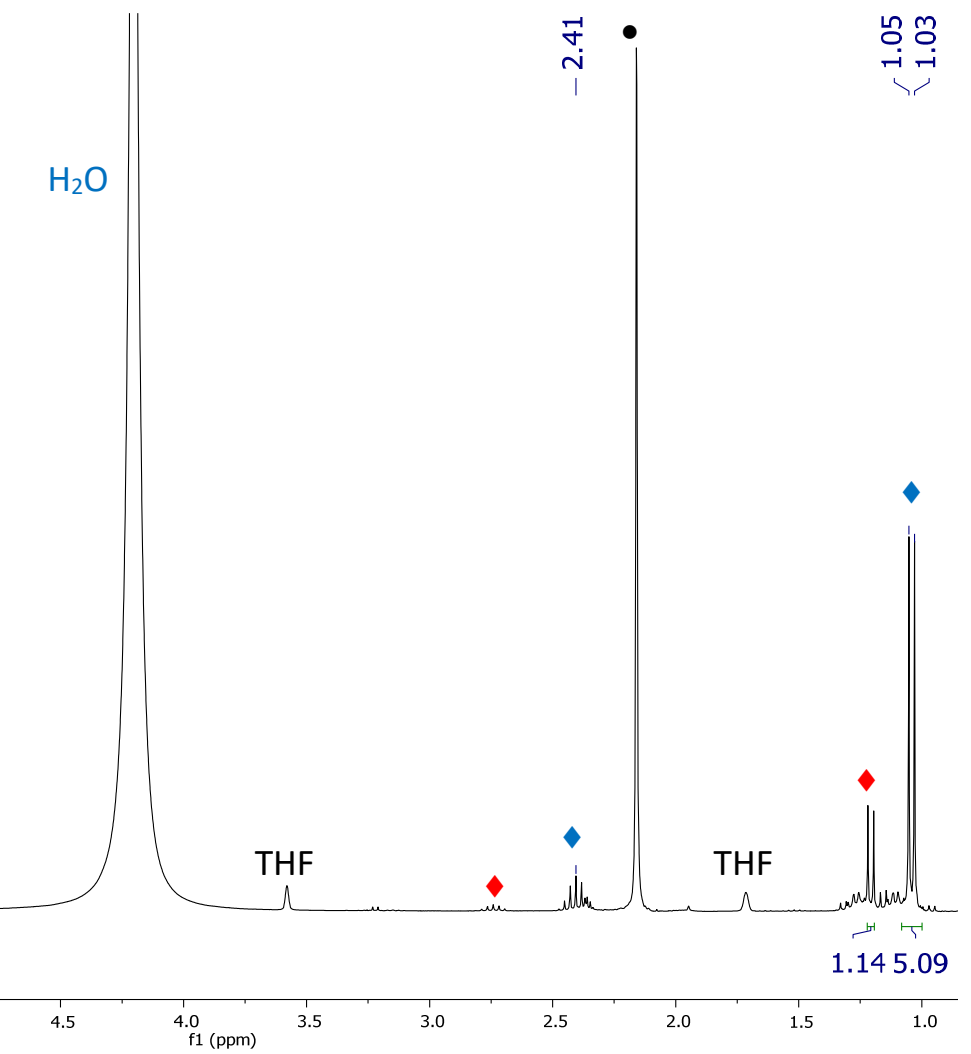

Figure S13. ${ }^{1} \mathrm{H}$ NMR $\left(300.13 \mathrm{MHz}\right.$, THF- $\left.d_{8}, 298 \mathrm{~K}\right)$ spectrum of the reaction mixture of the hydration of 2-methylpropionitrile $(\diamond)$ : formation of 2-methylpropanamide $(\diamond) \cdot \bullet$ Mesitylene. 
<smiles>CC(C)C(N)=O</smiles>

$\mathrm{CDCl}_{3}$

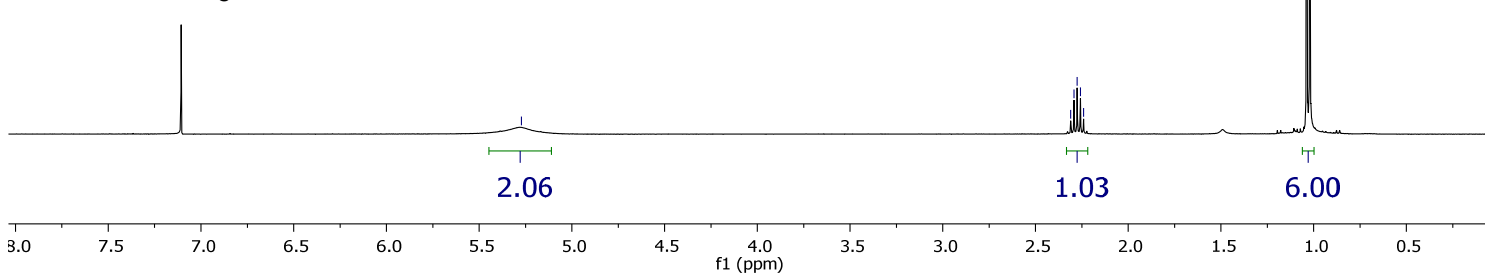

Figure S14. ${ }^{1} \mathrm{H}$ NMR (400.16 MHz, $\mathrm{CDCl}_{3}, 298 \mathrm{~K}$ ) spectrum of 2-methylpropanamide.

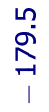<smiles>CC(C)C(N)=O</smiles>

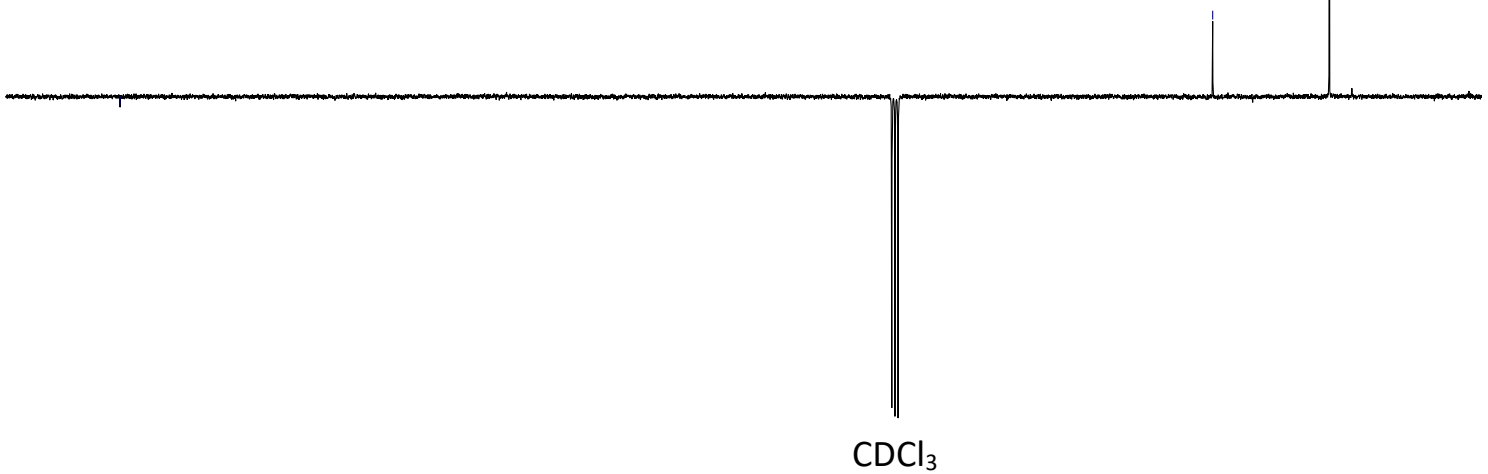

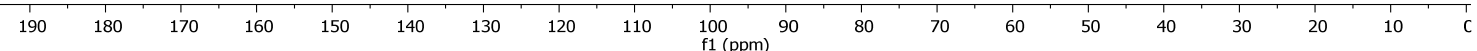

Figure S15. ${ }^{13} \mathrm{C}\left\{{ }^{1} \mathrm{H}\right\}$ APT $\mathrm{NMR}\left(75.48 \mathrm{MHz}, \mathrm{CDCl}_{3}, 298 \mathrm{~K}\right)$ spectrum of 2methylpropanamide. 


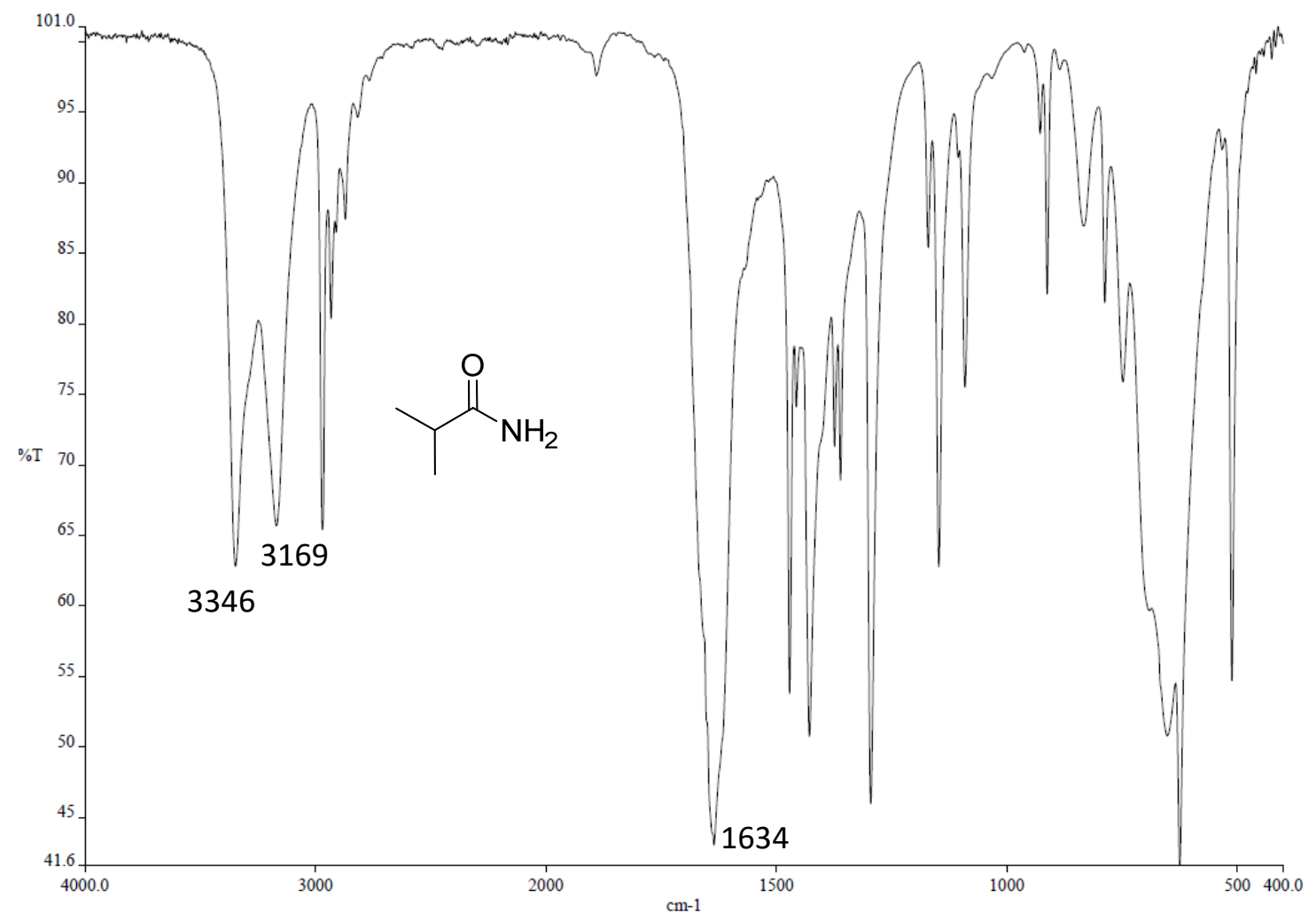

Figure S16. IR ATR spectrum of 2-methylpropanamide.

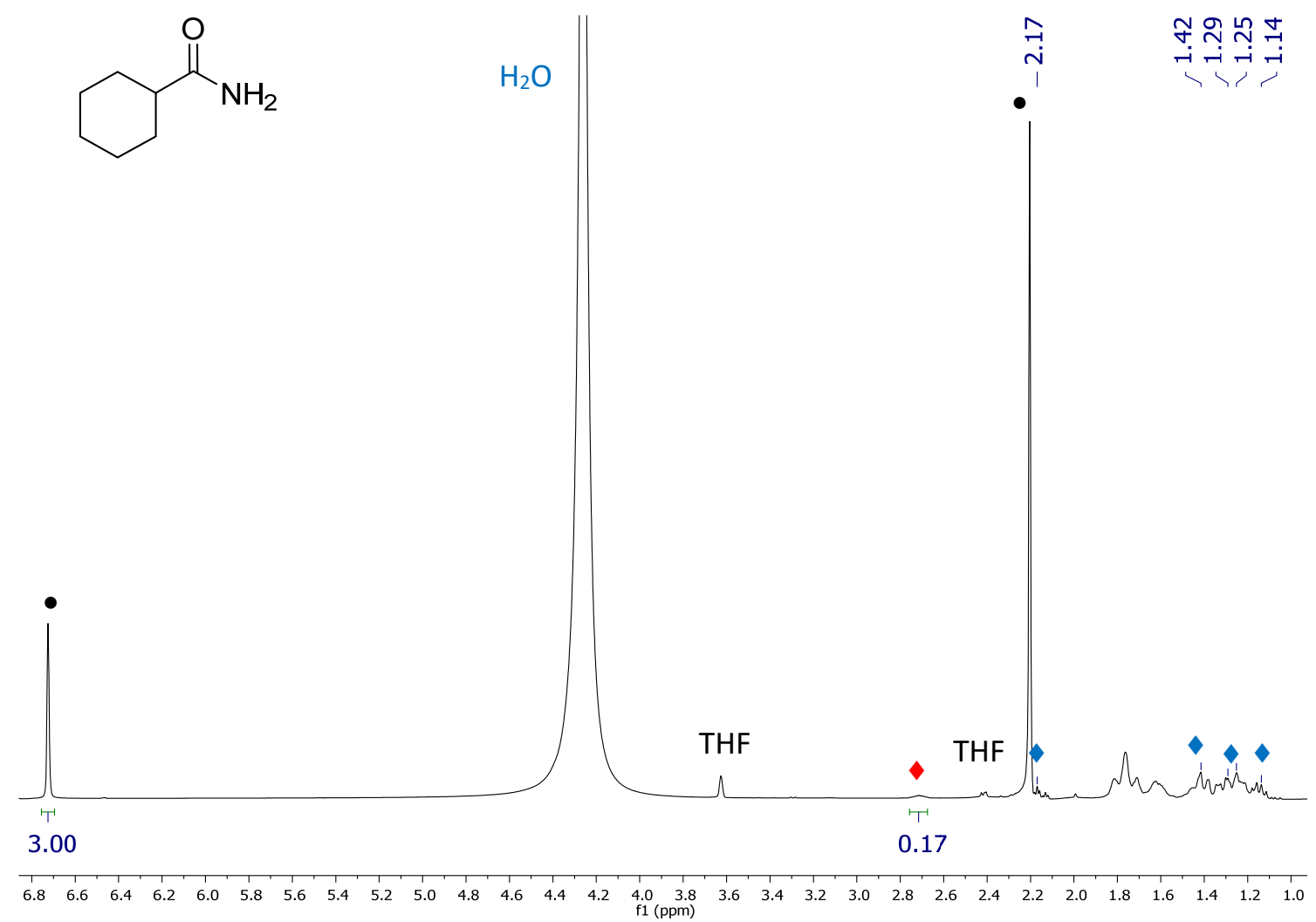

Figure S17. ${ }^{1} \mathrm{H}$ NMR $\left(300.13 \mathrm{MHz}\right.$, THF- $\left.d_{8}, 298 \mathrm{~K}\right)$ spectrum of the reaction mixture of the hydration of cyclohexanecarbonitrile $(\diamond)$ : formation of cyclohexanecarbamide $(\diamond)$. $\bullet$ Mesitylene. 
<smiles>NC(=O)C1CCCCC1</smiles>

$\mathrm{CDCl}_{3}$

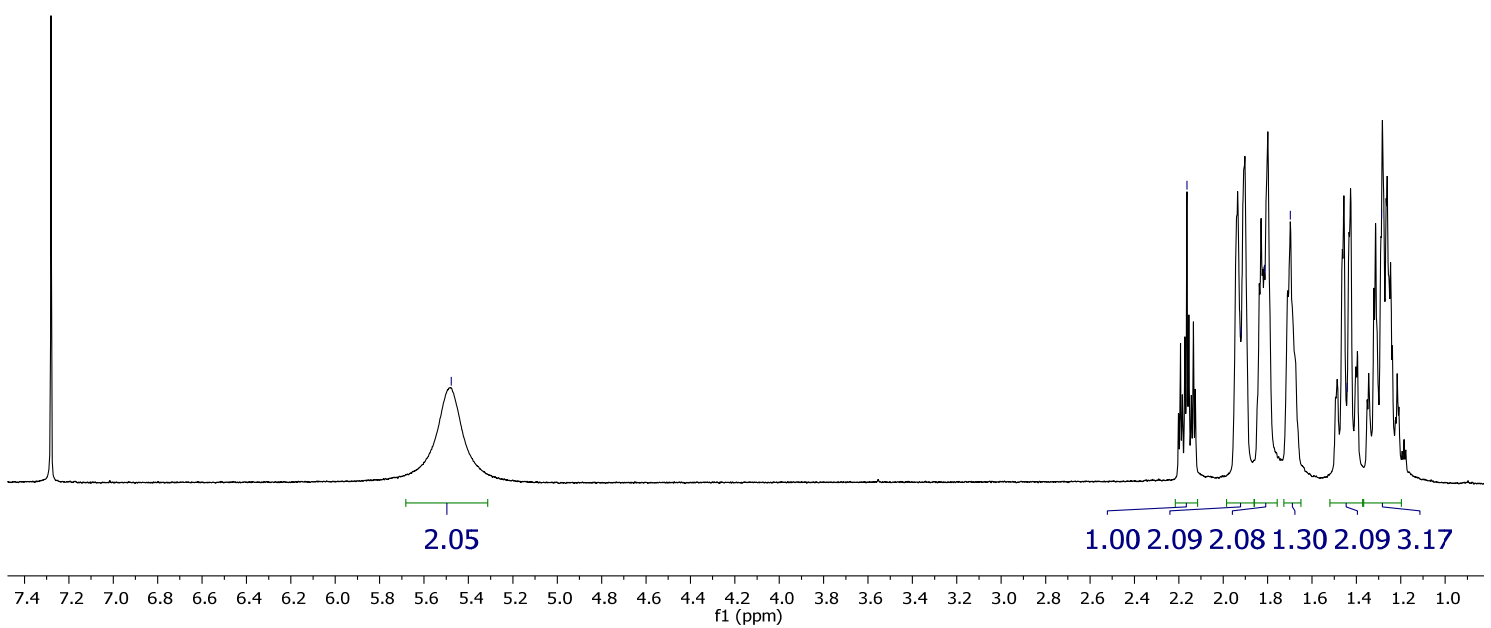

Figure S18. ${ }^{1} \mathrm{H}$ NMR $\left(400.16 \mathrm{MHz}, \mathrm{CDCl}_{3}, 298 \mathrm{~K}\right)$ spectrum of cyclohexanecarbamide.

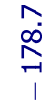<smiles>NC(=O)C1CCCCC1</smiles>

我

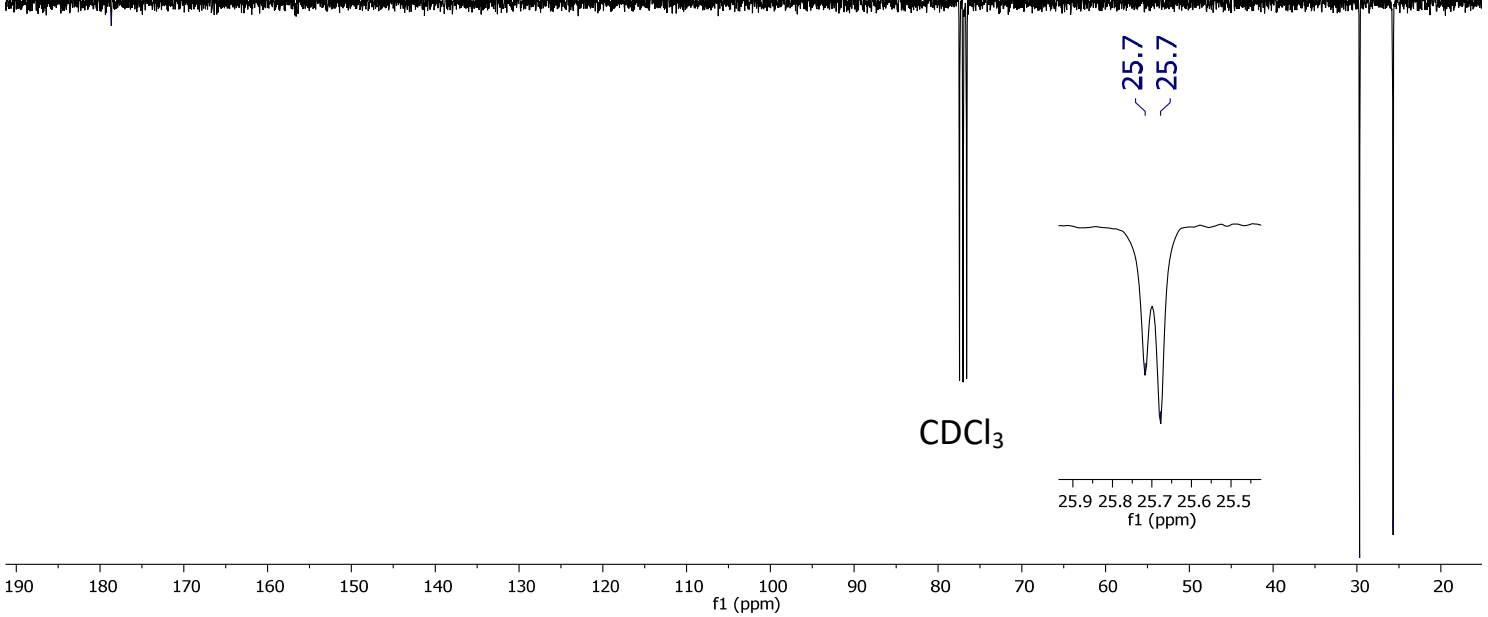

Figure S19. ${ }^{13} \mathrm{C}\left\{{ }^{1} \mathrm{H}\right\}$ APT NMR $\left(75.48 \mathrm{MHz}, \mathrm{CDCl}_{3}, 298 \mathrm{~K}\right)$ spectrum of cyclohexanecarbamide. 


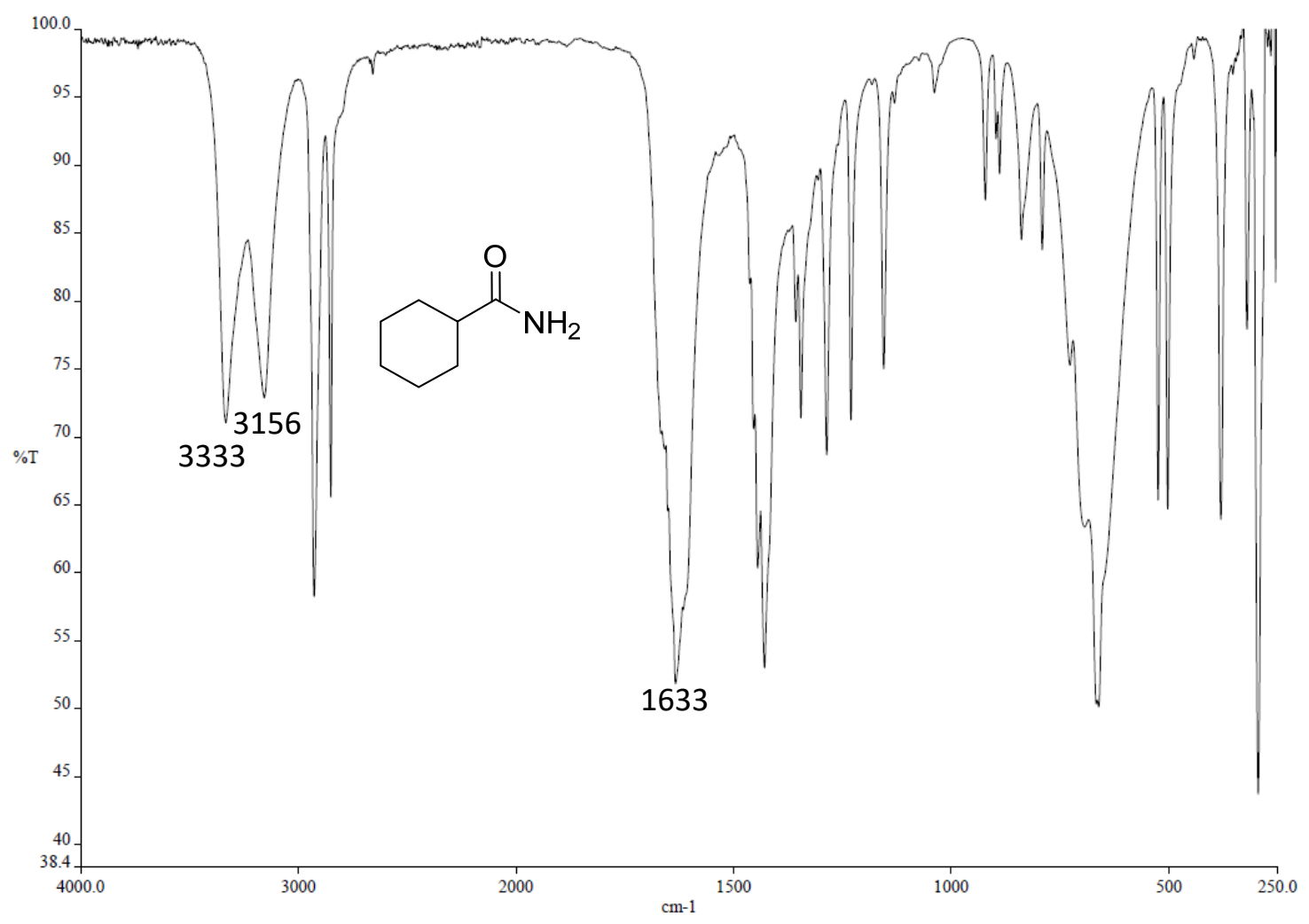

Figure S20. IR ATR spectrum of cyclohexanecarbamide.

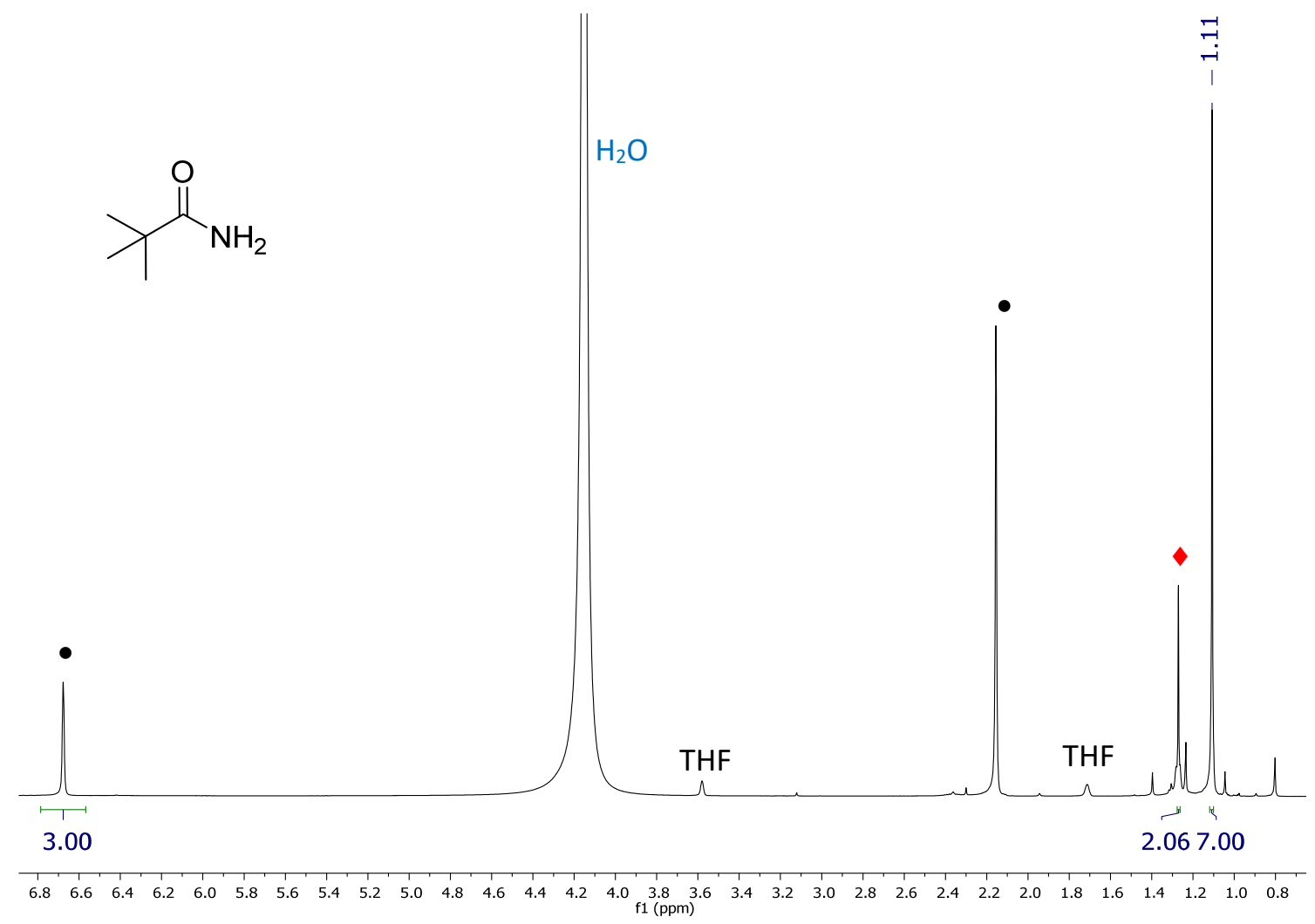

Figure S21. ${ }^{1} \mathrm{H}$ NMR $\left(300.13 \mathrm{MHz}\right.$, THF- $\left.d_{8}, 298 \mathrm{~K}\right)$ spectrum of the reaction mixture of the hydration of pivalonitrile $(\diamond)$ : formation of pivalamide $(\diamond) \cdot \bullet$ Mesitylene. 


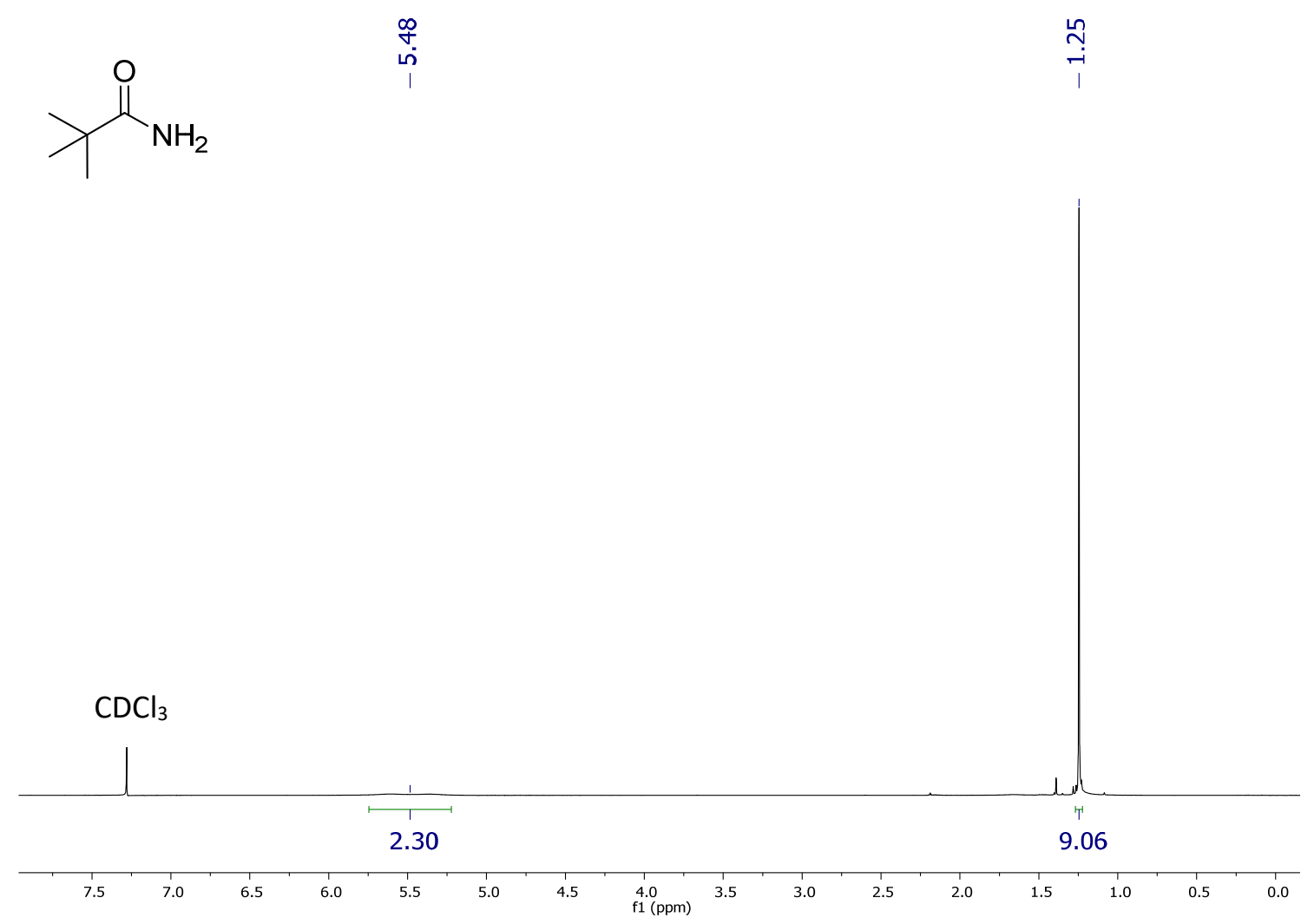

Figure S22. ${ }^{1} \mathrm{H} \mathrm{NMR}\left(400.16 \mathrm{MHz}, \mathrm{CDCl}_{3}, 298 \mathrm{~K}\right)$ spectrum of pivalamide.

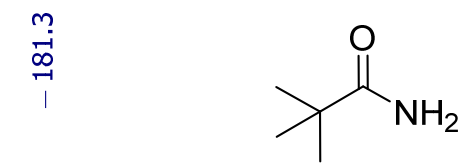

$\begin{array}{ll}0 & 0 \\ \infty & \hat{n} \\ 1 & 1\end{array}$

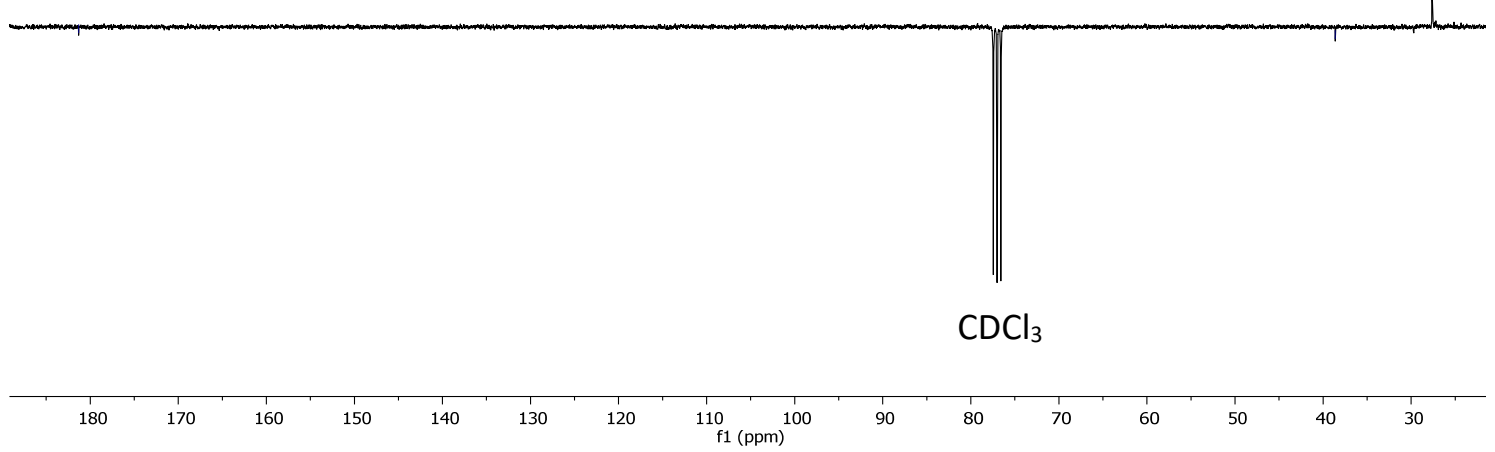

Figure S23. ${ }^{13} \mathrm{C}\left\{{ }^{1} \mathrm{H}\right\}$ APT NMR $\left(75.48 \mathrm{MHz}, \mathrm{CDCl}_{3}, 298 \mathrm{~K}\right)$ spectrum of pivalamide. 


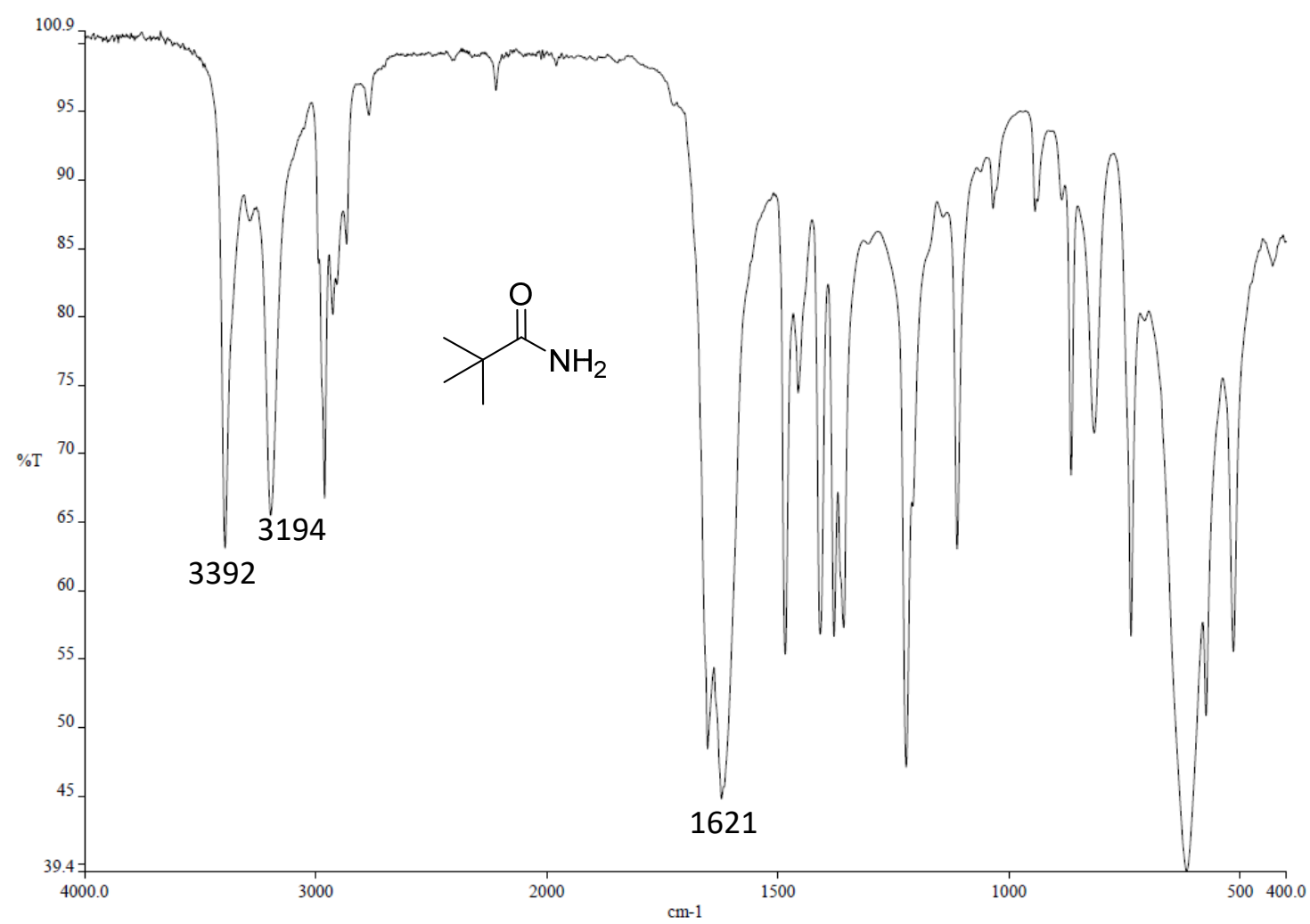

Figure S24. IR ATR spectrum of pivalamide.

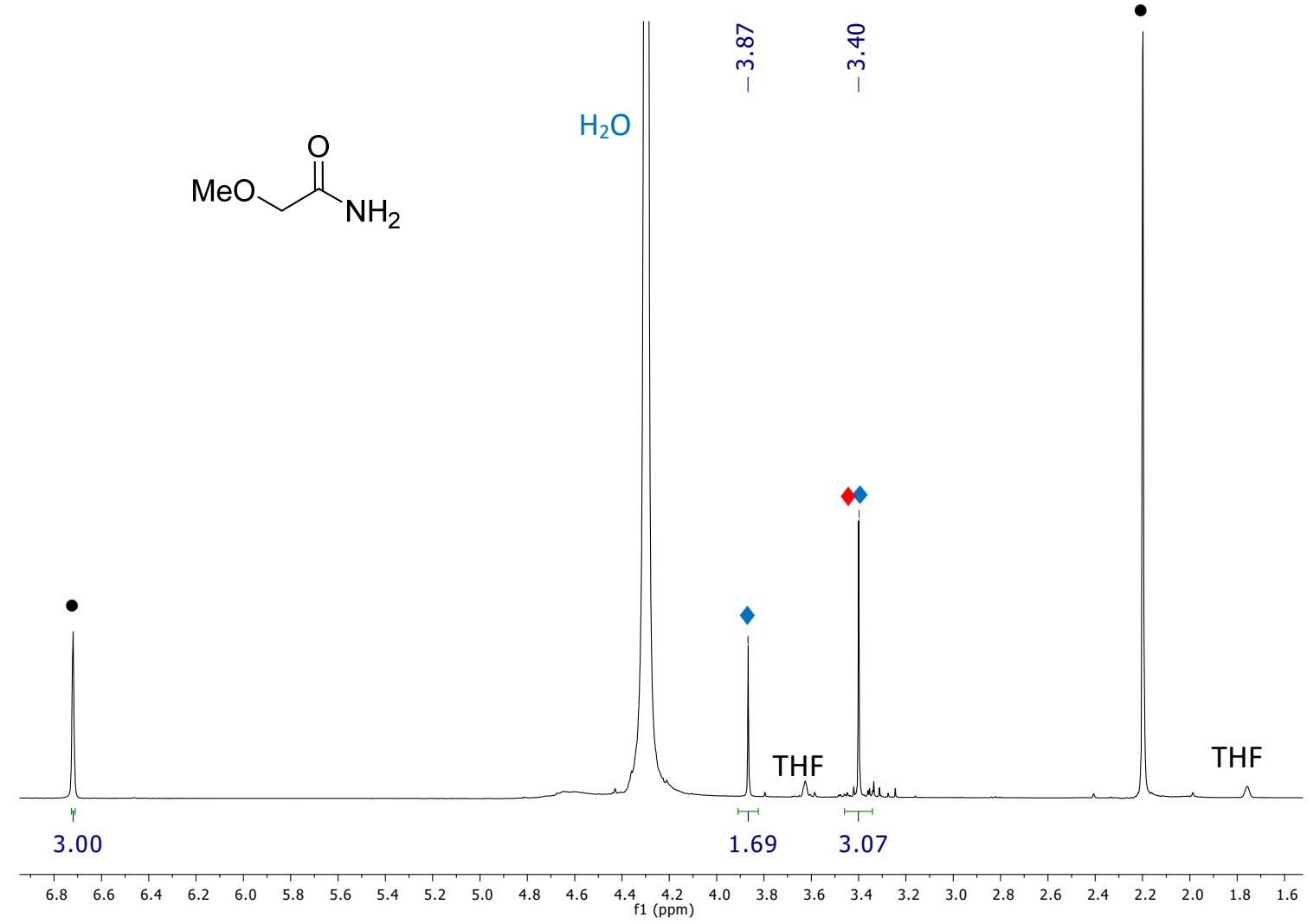

Figure S25. ${ }^{1} \mathrm{H}$ NMR $\left(300.13 \mathrm{MHz}\right.$, THF- $\left.d_{8}, 298 \mathrm{~K}\right)$ spectrum of the reaction mixture of the hydration of 2-methoxyacetonitrile $(\diamond)$ : formation of 2-methoxyacetamide $(\diamond)$. $\bullet$ Mesitylene. 


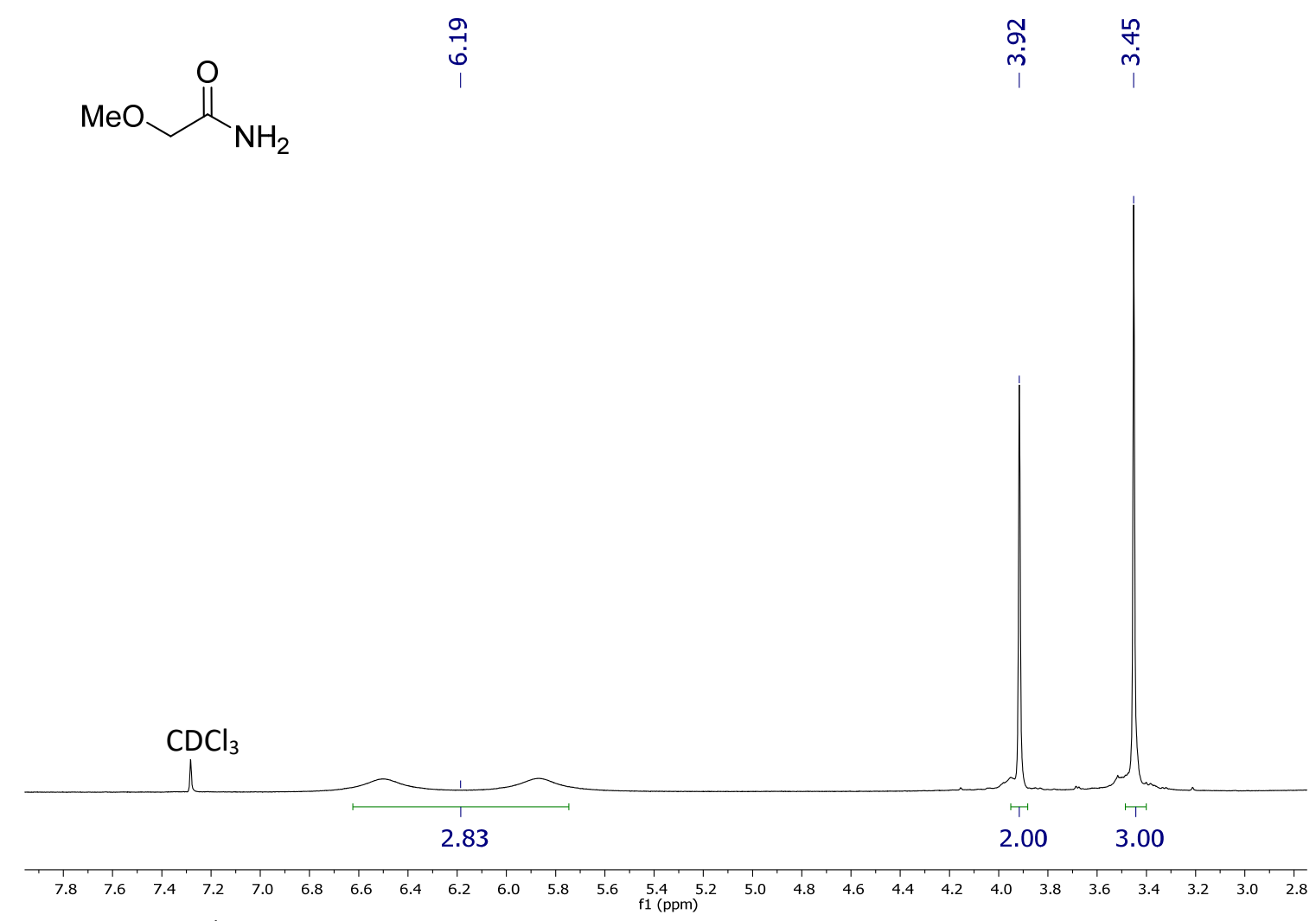

Figure S26. ${ }^{1} \mathrm{H}$ NMR (300.13 MHz, $\left.\mathrm{CDCl}_{3}, 298 \mathrm{~K}\right)$ spectrum of methoxyacetamide.

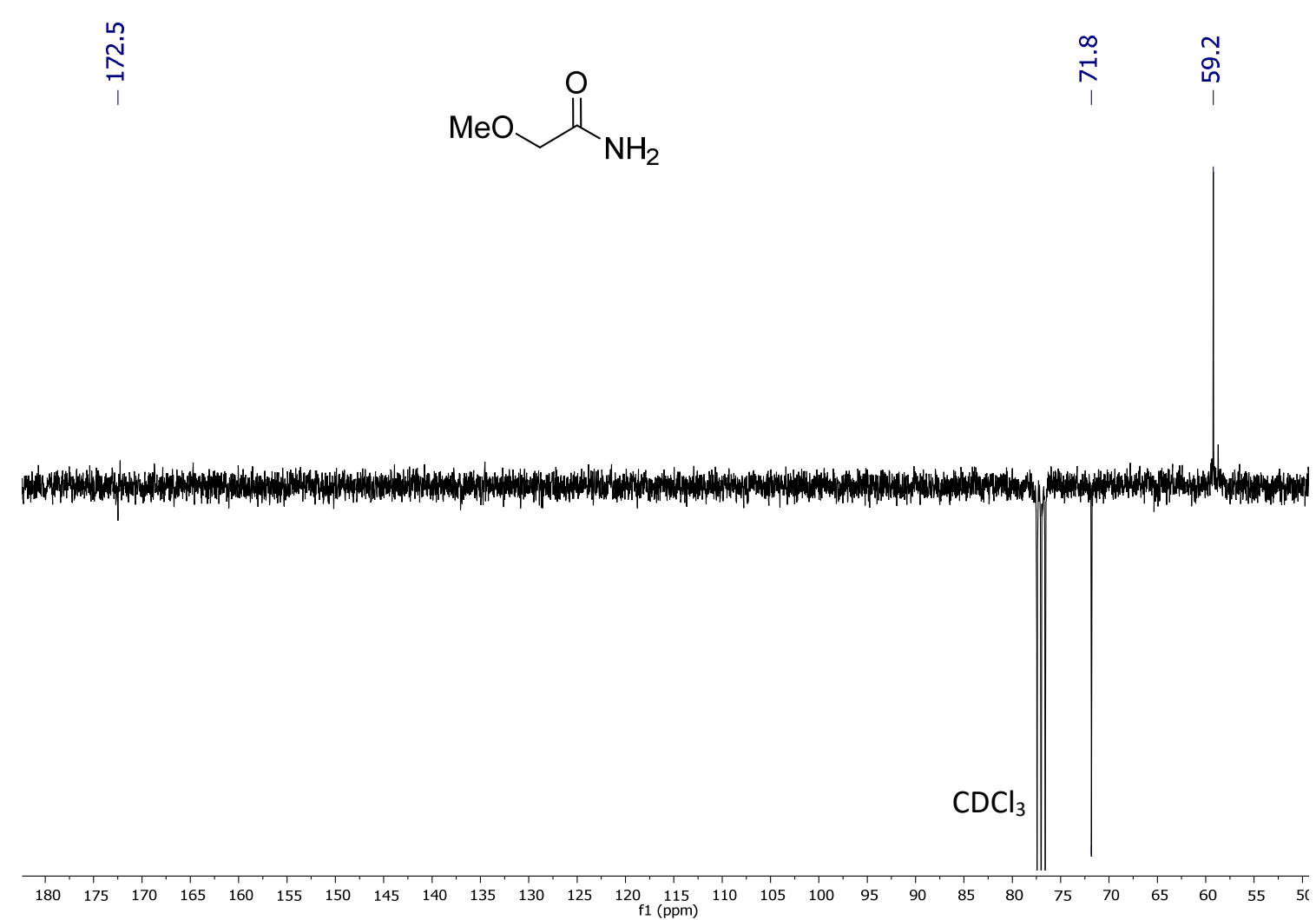

Figure S27. ${ }^{13} \mathrm{C}\left\{{ }^{1} \mathrm{H}\right\}$ APT NMR $\left(75.48 \mathrm{MHz}, \mathrm{CDCl}_{3}, 298 \mathrm{~K}\right)$ spectrum of methoxyacetamide. 


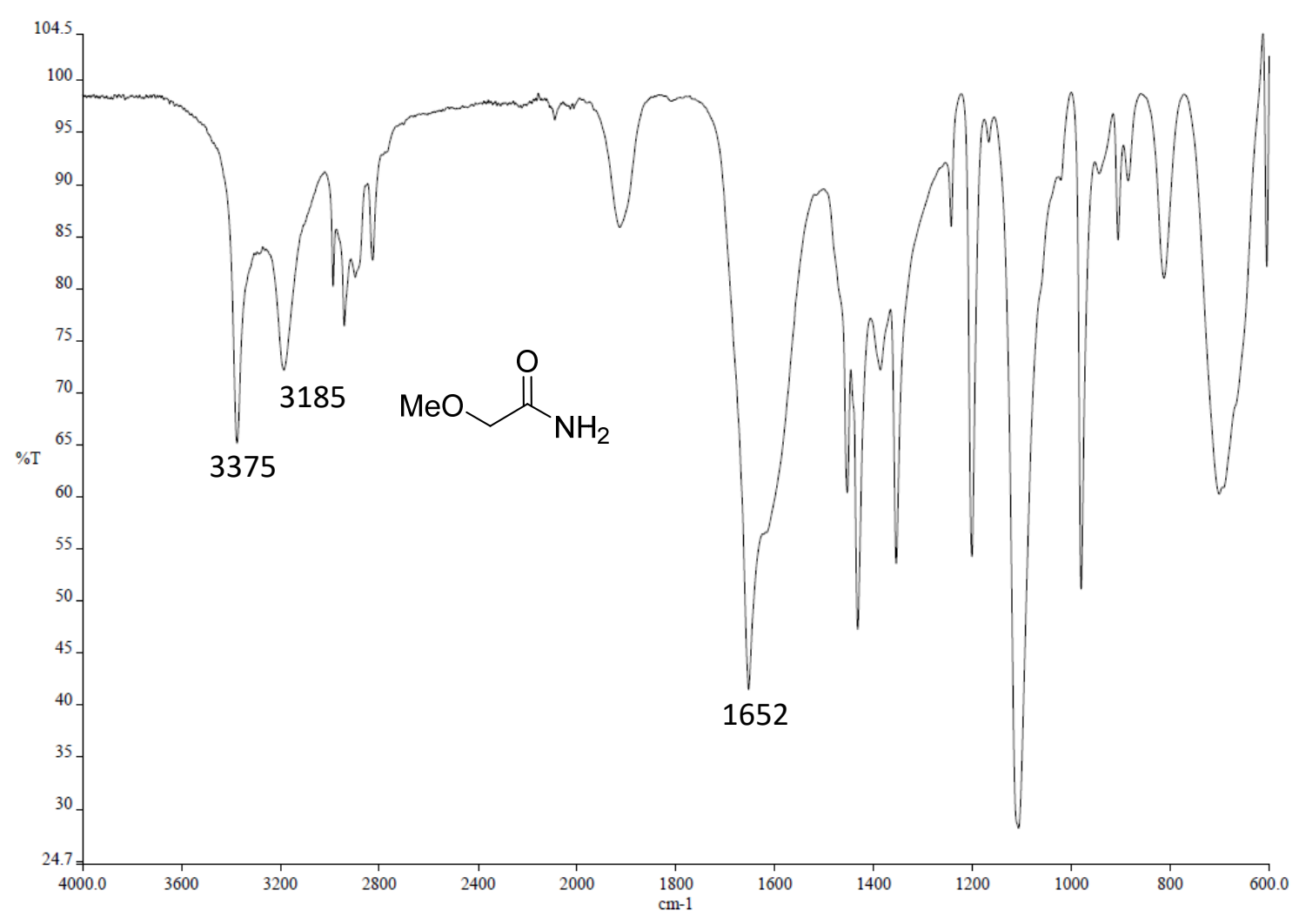

Figure S28. IR ATR spectrum of methoxyacetamide.<smiles>NC(=O)CCC(=O)c1ccccc1</smiles>

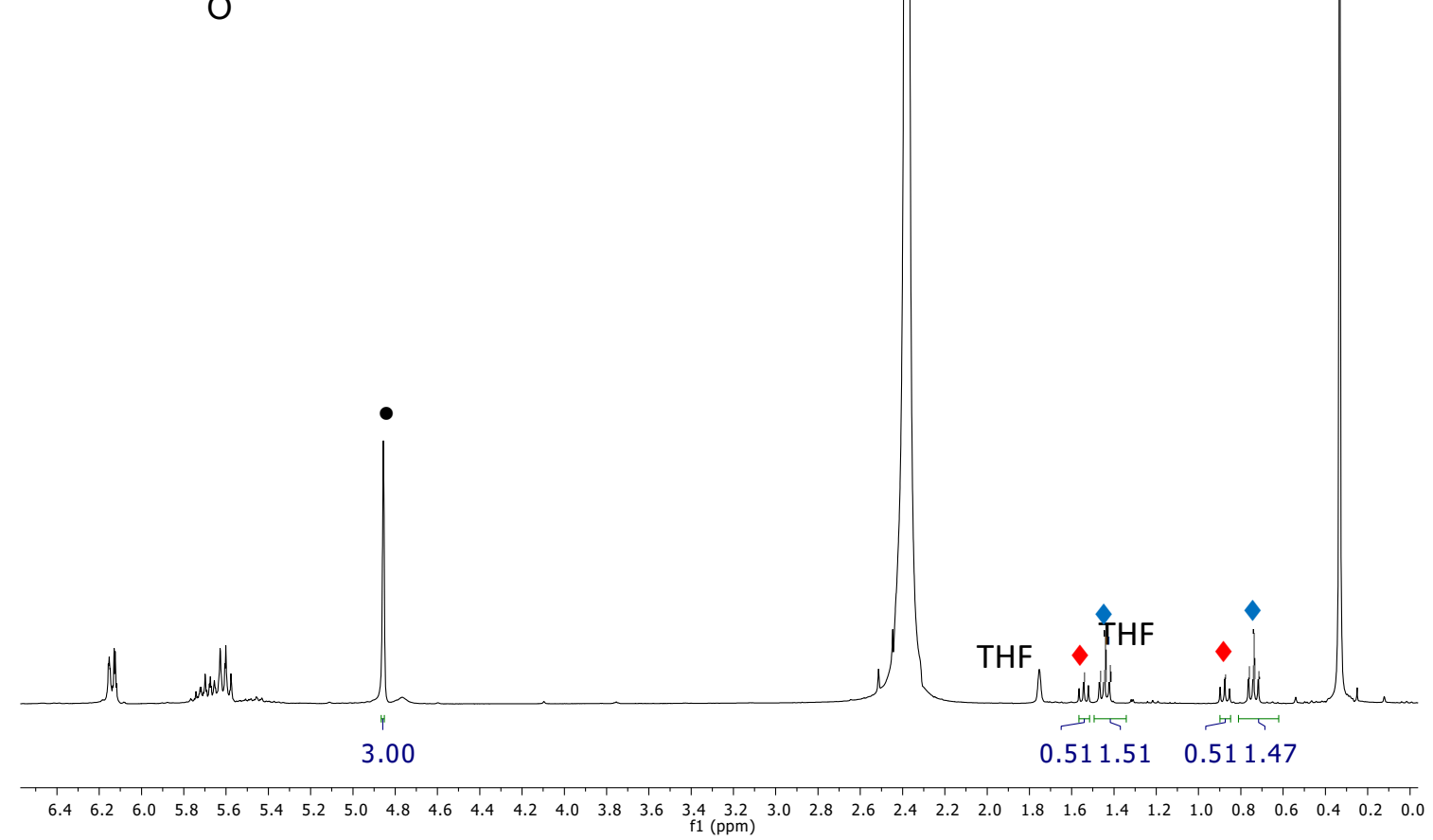

Figure S29. ${ }^{1} \mathrm{H}$ NMR $(300.13 \mathrm{MHz}$, THF- $d 8,298 \mathrm{~K})$ spectrum of the reaction mixture of the hydration of 4-oxo-4-phenylbutanonitrile $(\diamond)$ : formation of 4-oxo-4phenylbutanamide $(\diamond) \cdot \bullet$ Mesitylene. 


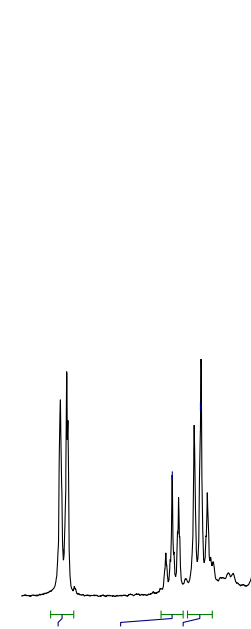<smiles>NC(=O)CCC(=O)c1ccccc1</smiles>

Figure S30. ${ }^{1} \mathrm{H}$ NMR (300.13 $\left.\mathrm{MHz}, \mathrm{CDCl}_{3}, 298 \mathrm{~K}\right)$ spectrum of 4-oxo-4phenylbutanamide.

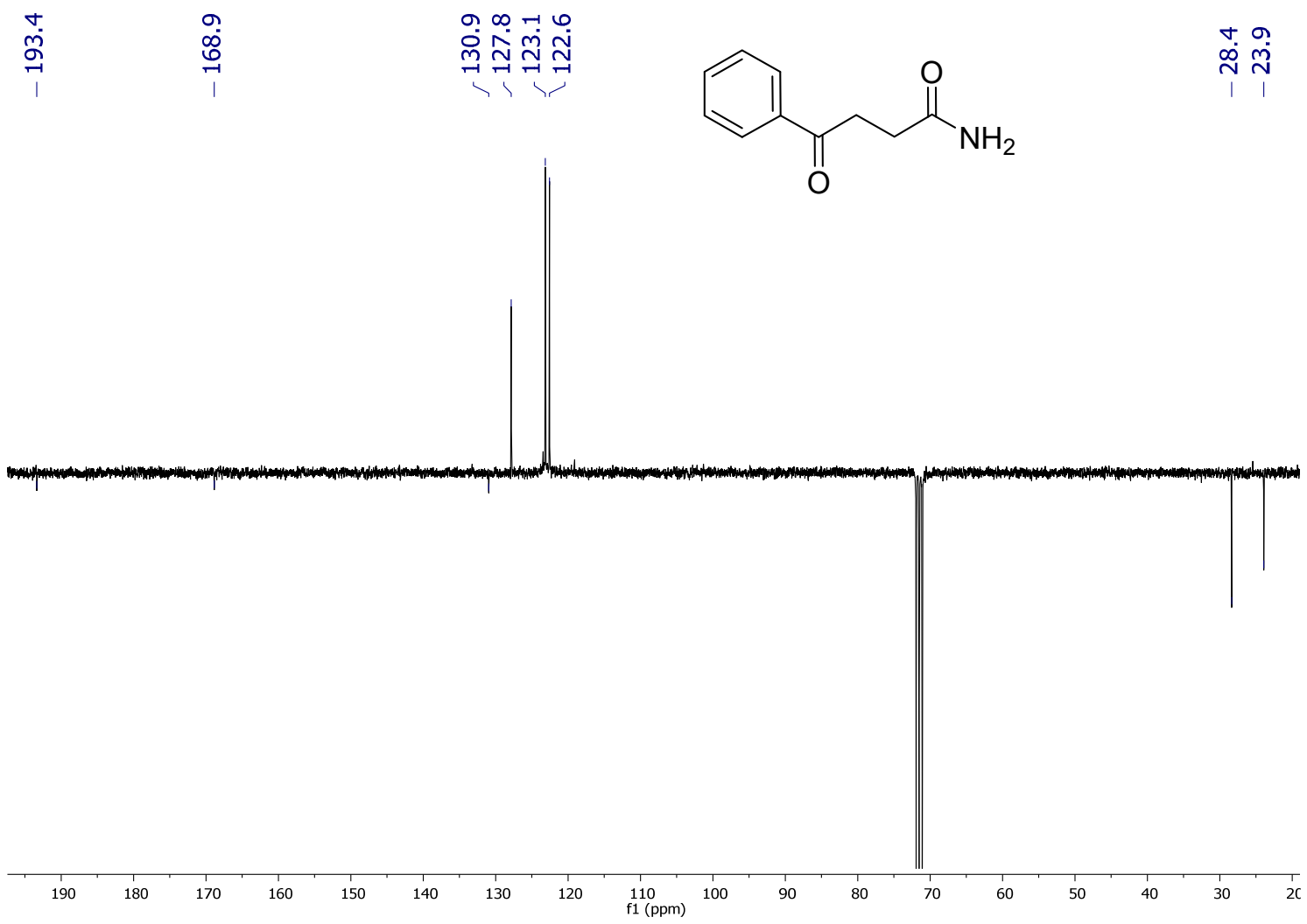

Figure S31. ${ }^{13} \mathrm{C}\left\{{ }^{1} \mathrm{H}\right\}$ APT NMR $\left(75.48 \mathrm{MHz}, \mathrm{CDCl}_{3}, 298 \mathrm{~K}\right)$ spectrum of 4-oxo-4phenylbutanamide. 


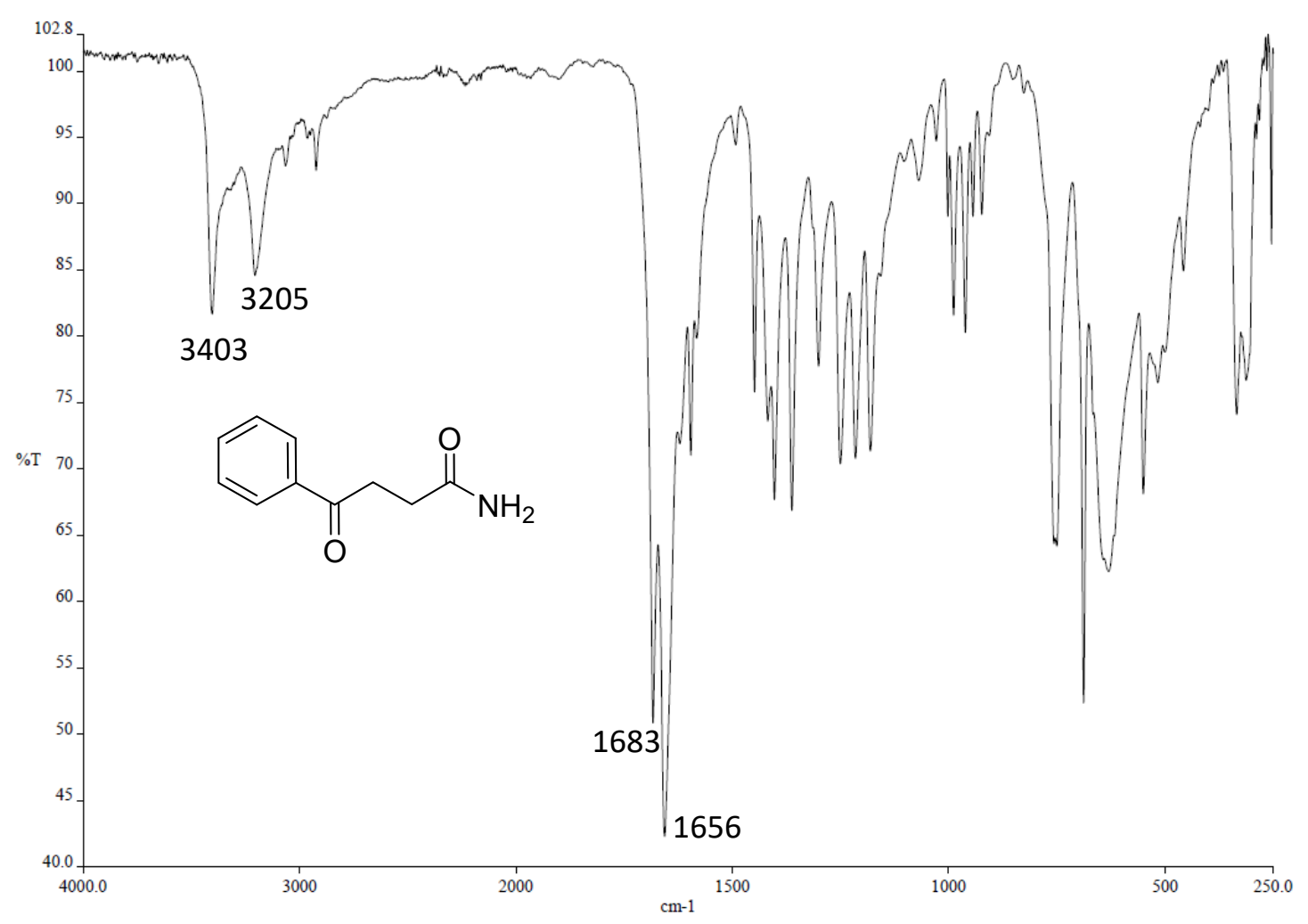

Figure S32. IR ATR spectrum of 4-oxo-4-phenylbutanamide.<smiles>NC(=O)Cc1ccccc1</smiles>

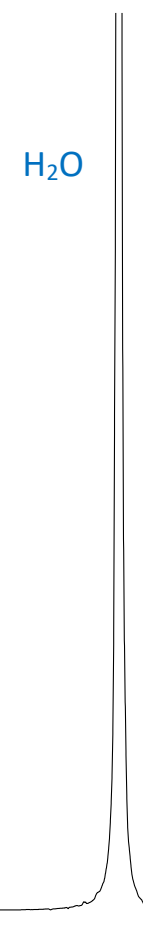

THF

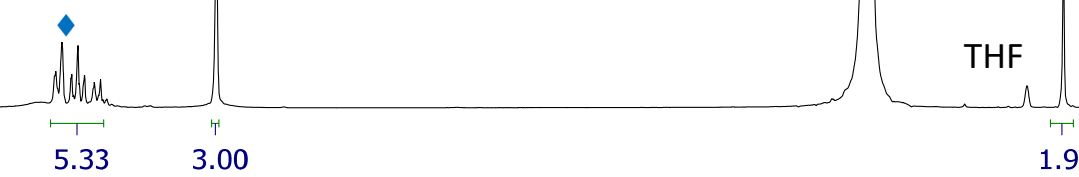

$\begin{array}{llllllllllllllllllllllllllllllll}7.4 & 7.2 & 7.0 & 6.8 & 6.6 & 6.4 & 6.2 & 6.0 & 5.8 & 5.6 & 5.4 & 5.2 & 5.0 & \begin{array}{c}4.8 \\ \mathrm{f1}(\mathrm{ppm})\end{array} & 4.4 & 4.2 & 4.0 & 3.8 & 3.6 & 3.4 & 3.2 & 3.0 & 2.8 & 2.6 & 2.4 & 2.2 & 2.0\end{array}$

Figure S33. ${ }^{1} \mathrm{H}$ NMR $(300.13 \mathrm{MHz}$, THF- $d 8,298 \mathrm{~K})$ spectrum of the reaction mixture of the hydration of 2-phenylacetonitrile $(\diamond)$ : formation of 2-phenylacetamide $(\diamond)$. $\bullet$ Mesitylene. 


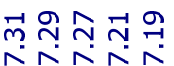

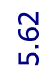<smiles>NC(=O)Cc1ccccc1</smiles>

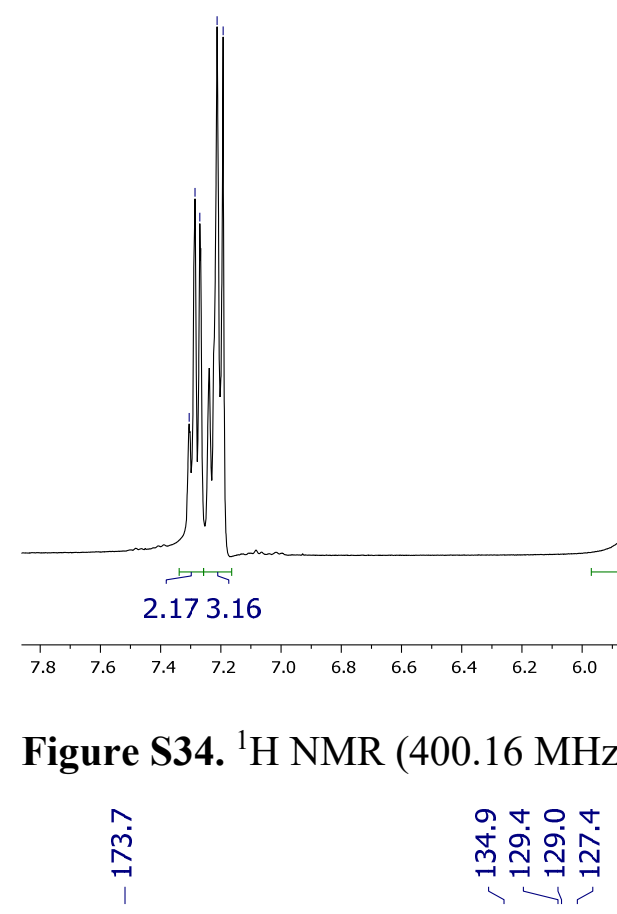

$\mathrm{NH}_{2}$

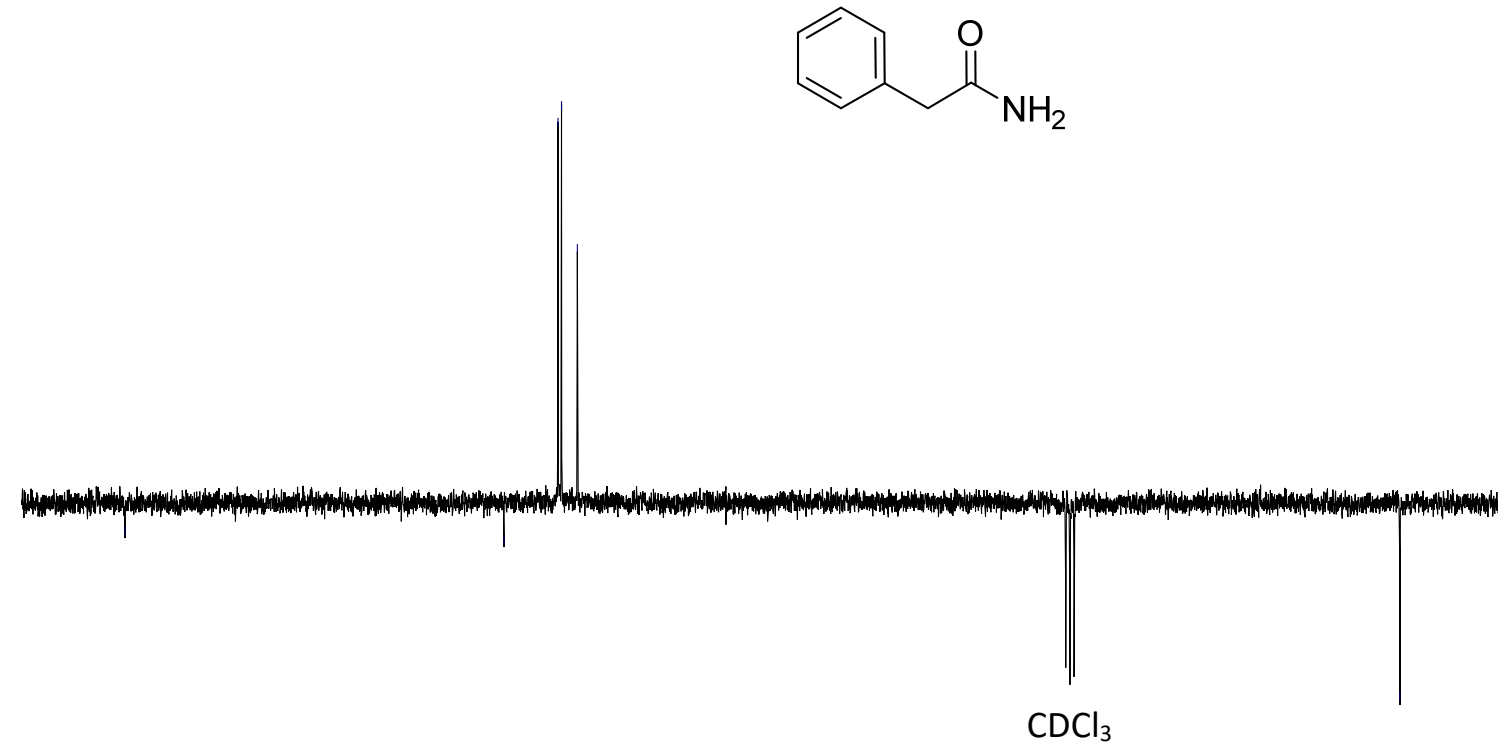

$\begin{array}{lllllllllllllllllllllllllllllllllll}180 & 175 & 170 & 165 & 160 & 155 & 150 & 145 & 140 & 135 & 130 & 125 & 120 & 115 & \begin{array}{c}110 \\ \mathrm{f} 1(\mathrm{ppm})\end{array} & 100 & 95 & 90 & 85 & 80 & 75 & 70 & 65 & 60 & 55 & 50 & 45 & 40 & 35\end{array}$

Figure S35. ${ }^{13} \mathrm{C}\left\{{ }^{1} \mathrm{H}\right\}$ APT NMR $\left(75.48 \mathrm{MHz}, \mathrm{CDCl}_{3}, 298 \mathrm{~K}\right)$ spectrum of 2phenylacetamide. 


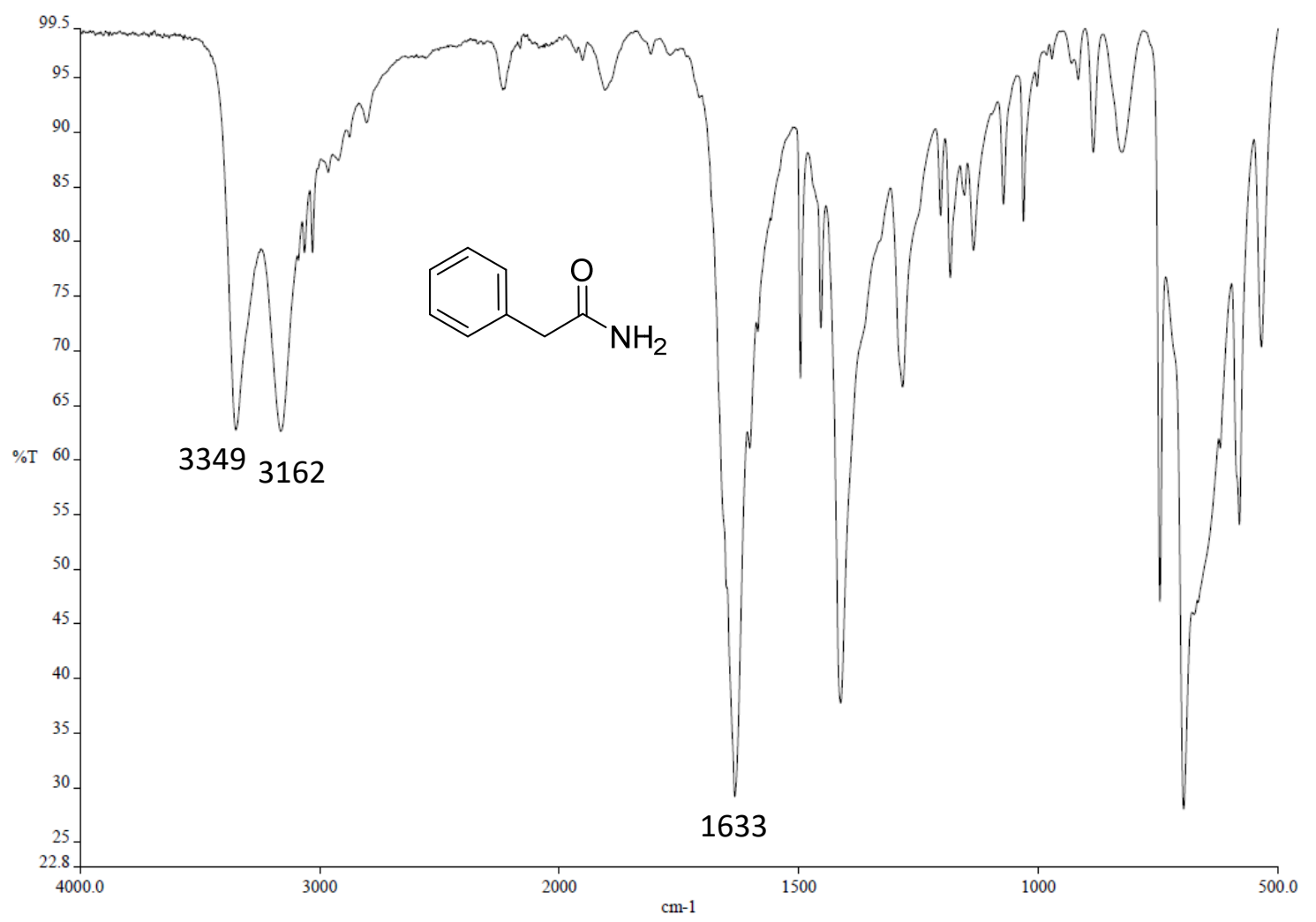

Figure S36. IR ATR spectrum of 2-phenylacetamide.

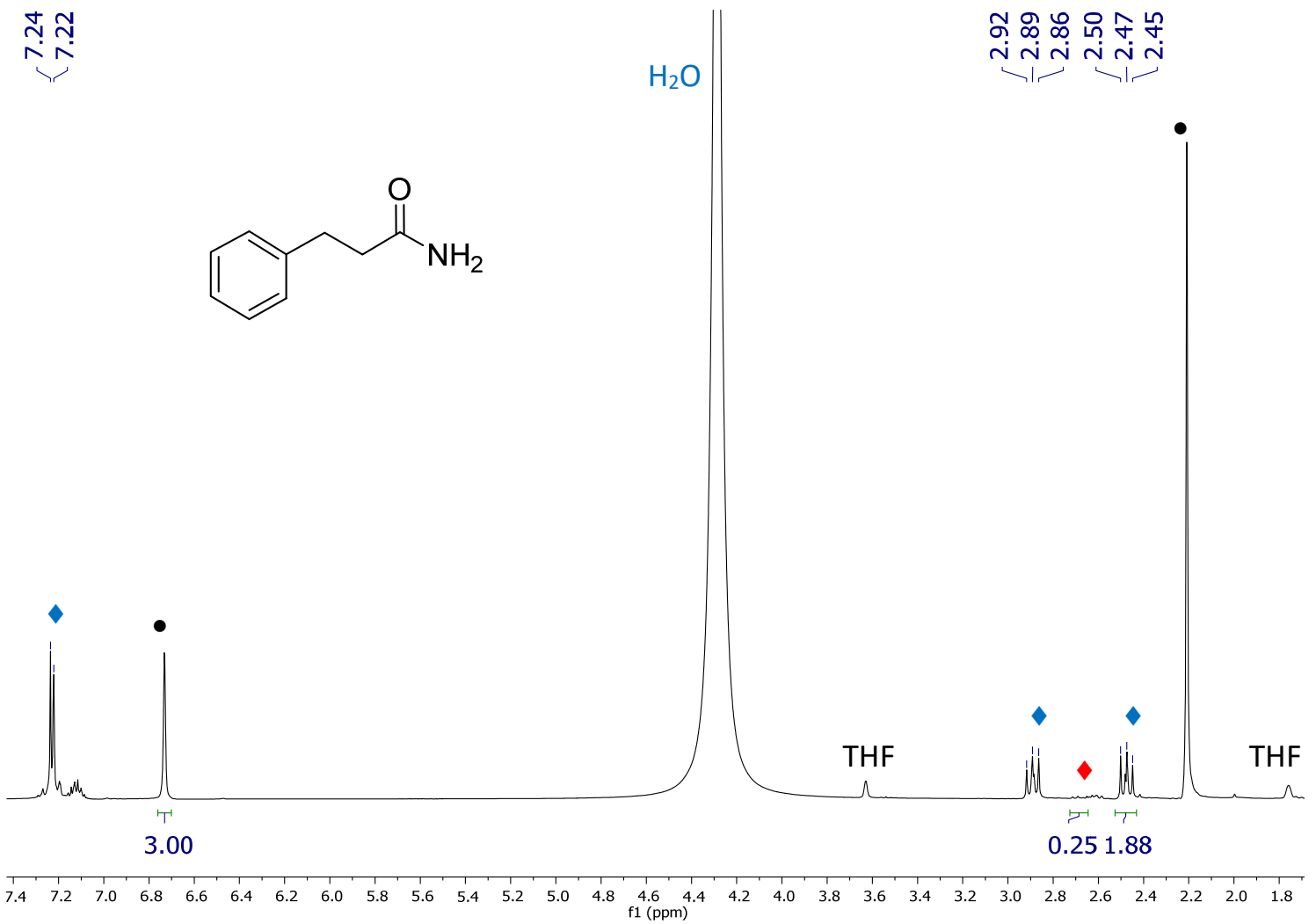

Figure S37. ${ }^{1} \mathrm{H}$ NMR $\left(300.13 \mathrm{MHz}\right.$, THF- $\left.d_{8}, 298 \mathrm{~K}\right)$ spectrum of the reaction mixture of the hydration of 3-phenylpropanenitrile $(\diamond)$ : formation of 3-phenylpropanamide $(\diamond)$. $\bullet$ Mesitylene. 


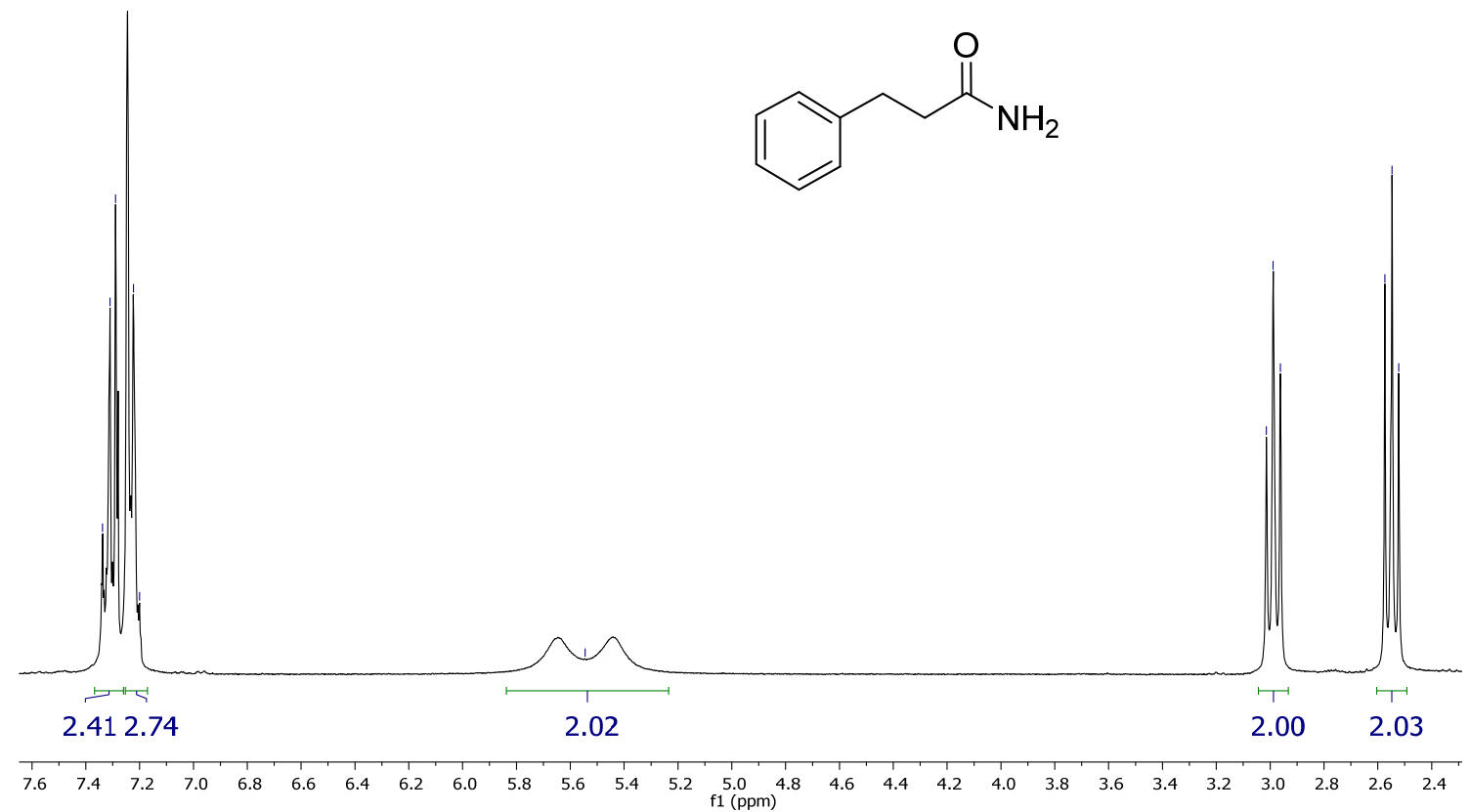

Figure S38. ${ }^{1} \mathrm{H}$ NMR $\left(300.13 \mathrm{MHz}, \mathrm{CDCl}_{3}, 298 \mathrm{~K}\right)$ spectrum of 3-phenylpropanamide.

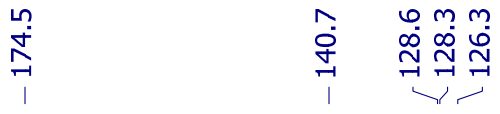

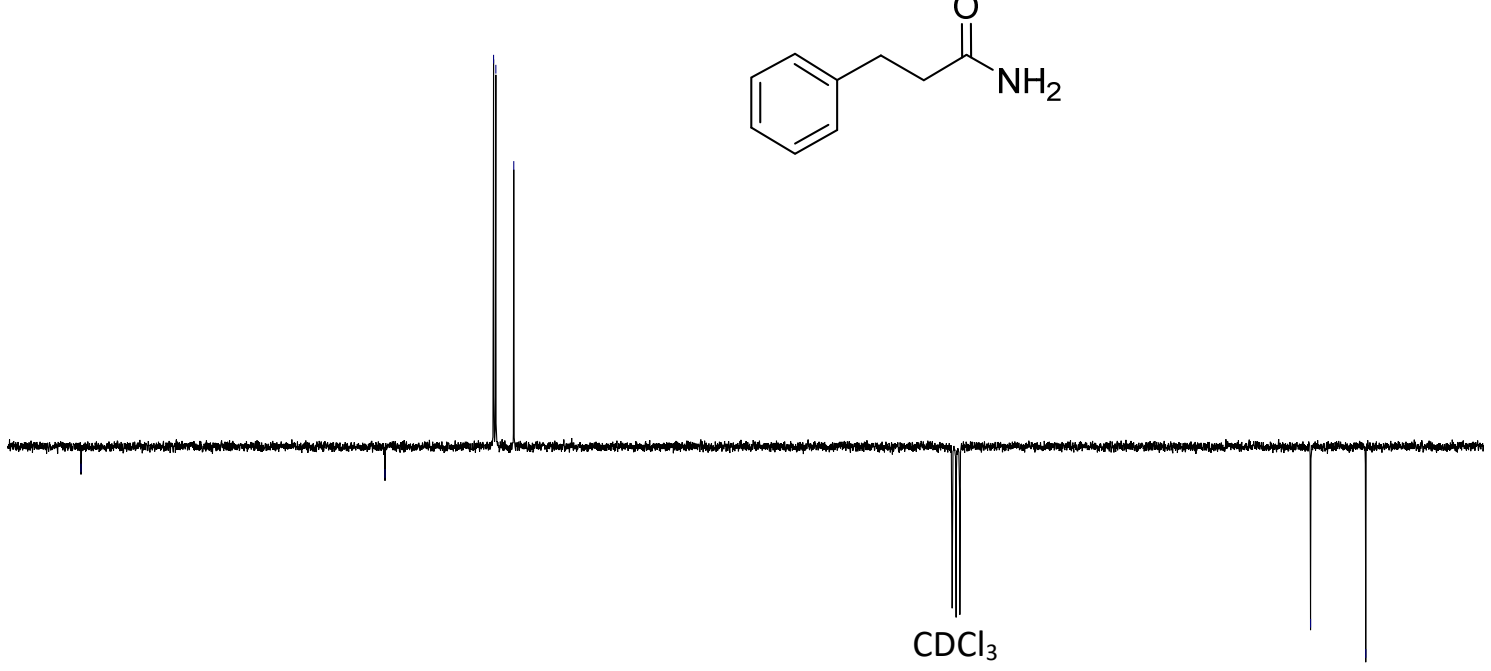

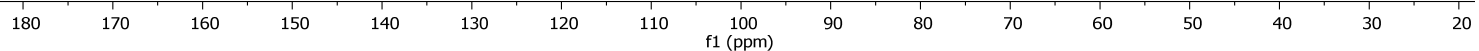

Figure S39. ${ }^{13} \mathrm{C}\left\{{ }^{1} \mathrm{H}\right\}$ APT NMR $\left(75.48 \mathrm{MHz}, \mathrm{CDCl}_{3}, 298 \mathrm{~K}\right)$ spectrum of 3phenylpropanamide. 


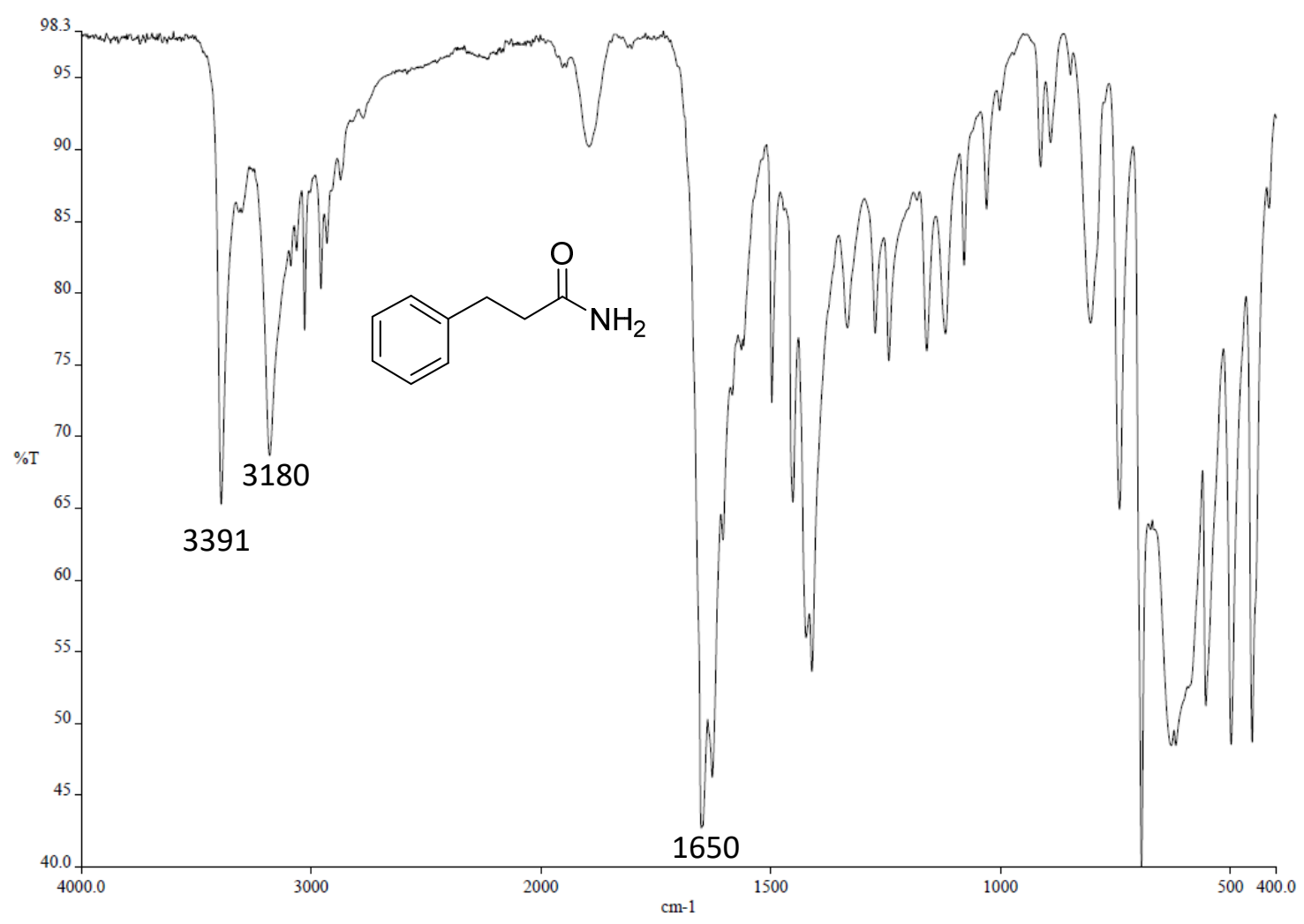

Figure S40. IR ATR spectrum of 3-phenylpropanamide.

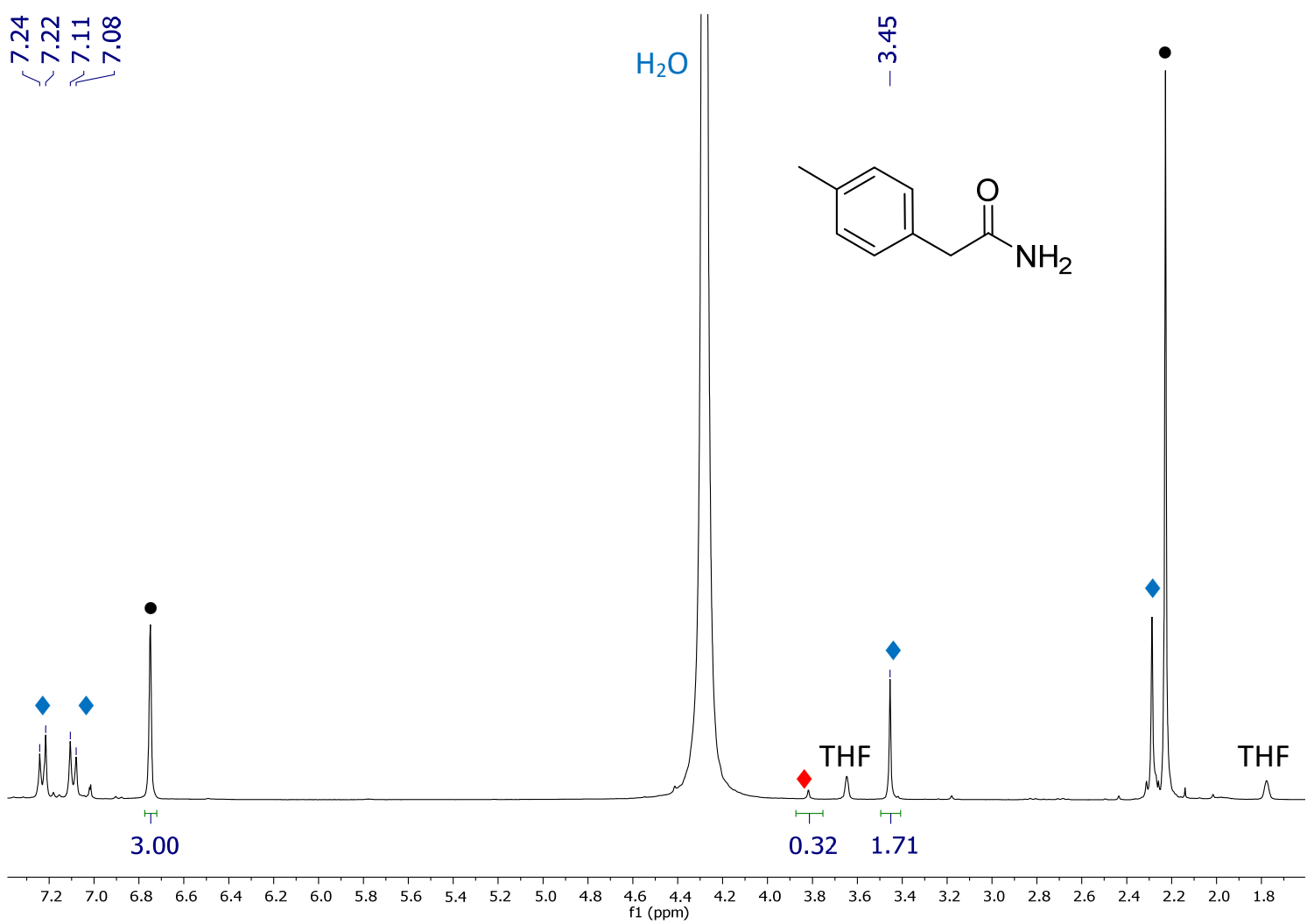

Figure S41. ${ }^{1} \mathrm{H}$ NMR $\left(300.13 \mathrm{MHz}, \mathrm{THF}-d_{8}, 298 \mathrm{~K}\right)$ spectrum of the reaction mixture of the hydration of $p$-tolylacetonitrile $(\diamond)$ : formation of $p$-tolylacetamide $(\diamond) \cdot \bullet$ Mesitylene. 
<smiles>Cc1ccc(CC(N)=O)cc1</smiles>

$\mathrm{H}_{2}$

\section{$\mathrm{CDCl}_{3}$}

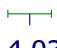

Figure S42. ${ }^{1} \mathrm{H}$ NMR $\left(400.16 \mathrm{MHz}, \mathrm{CDCl}_{3}, 298 \mathrm{~K}\right)$ spectrum of $p$-tolylacetamide.
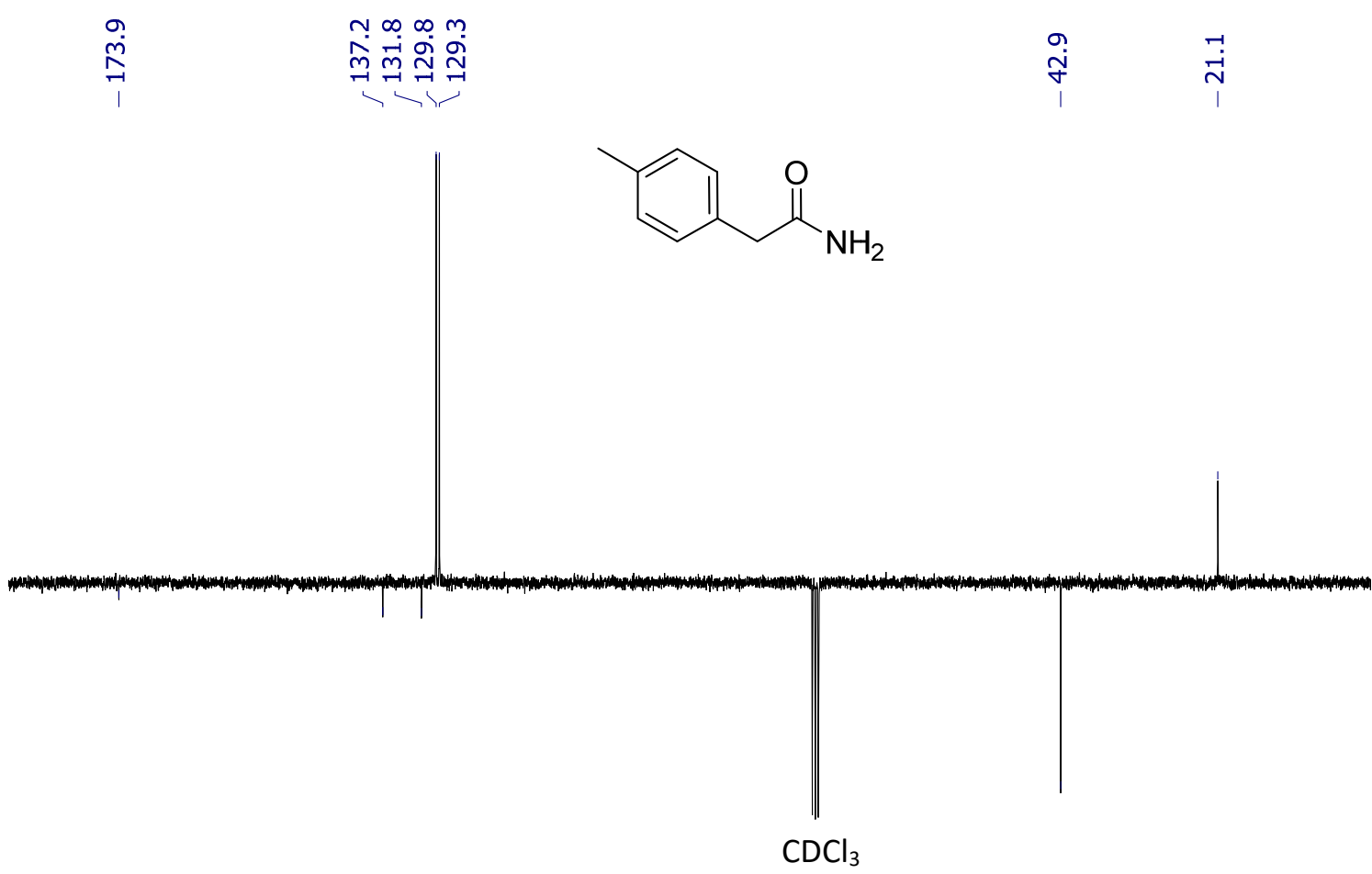

\begin{tabular}{rlllllllllllllllll}
\hline 180 & 170 & 160 & 150 & 140 & 130 & 120 & 110 & $\underset{\mathrm{f} 1(\mathrm{ppm})}{100}$ & 80 & 70 & 60 & 50 & 40 & 30 & 20 & 10 & 1
\end{tabular}

Figure S43. ${ }^{13} \mathrm{C}\left\{{ }^{1} \mathrm{H}\right\}$ APT NMR (75.48 $\left.\mathrm{MHz}, \mathrm{CDCl}_{3}, 298 \mathrm{~K}\right)$ spectrum of $p$ tolylacetamide. 


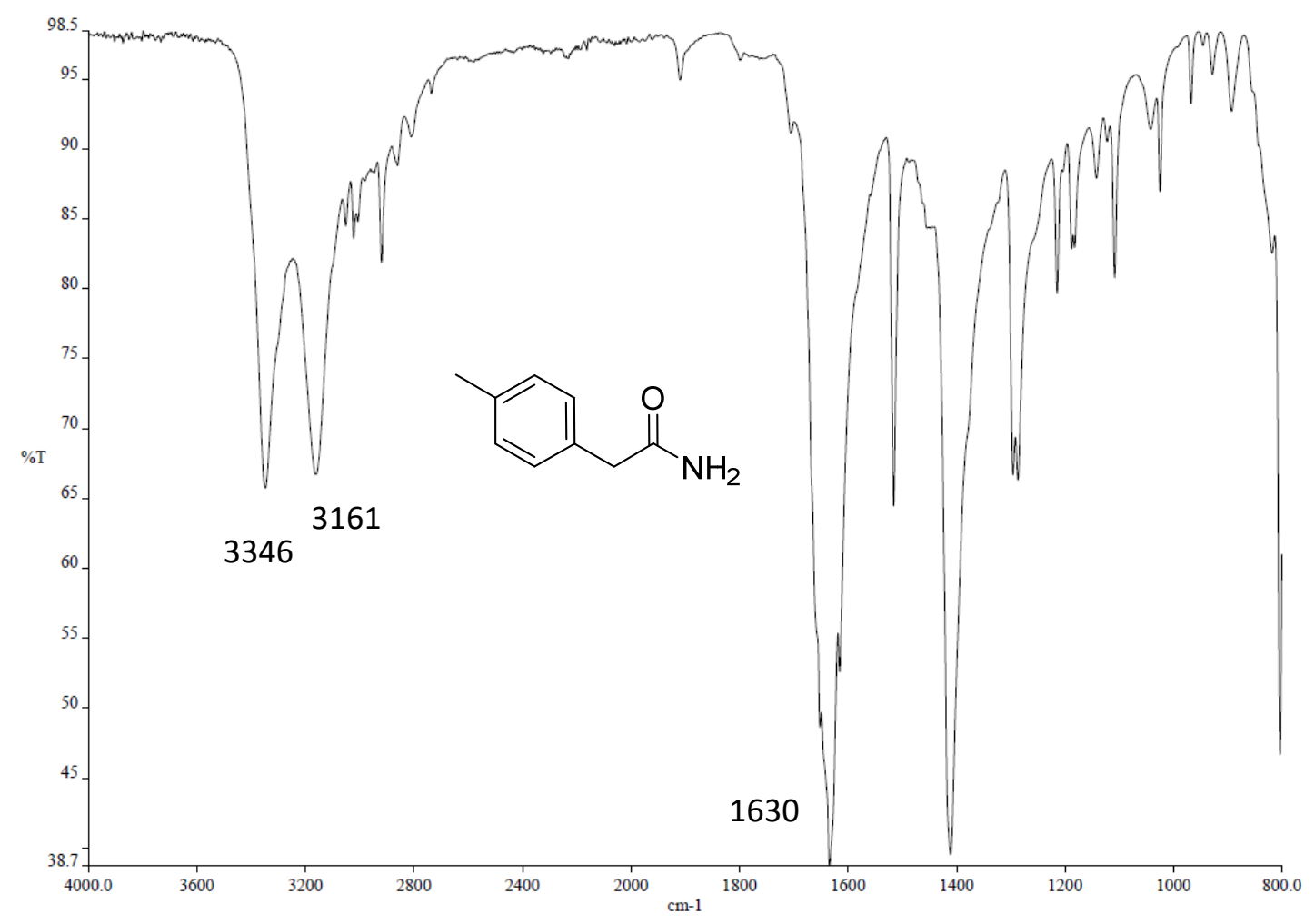

Figure S44. IR ATR spectrum of $p$-tolylacetamide.

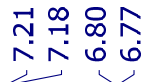

$\mathrm{MeO}$<smiles>Cc1ccc(CC(N)=O)cc1</smiles>

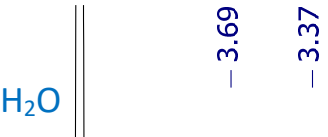

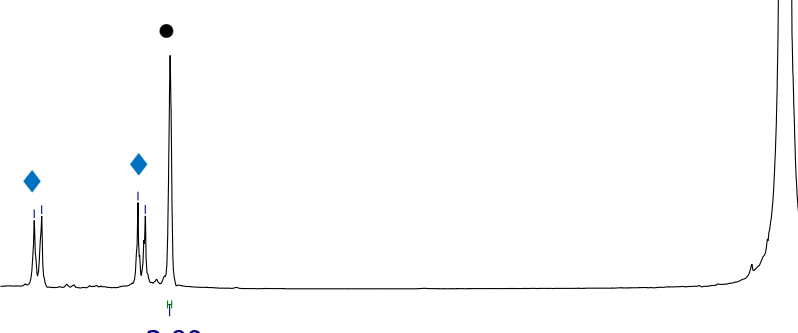

3.00
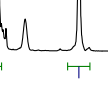

3.081 .97

$\begin{array}{lllllllllllllllllllllllllllllllllllll}7.2 & 7.0 & 6.8 & 6.6 & 6.4 & 6.2 & 6.0 & 5.8 & 5.6 & 5.4 & 5.2 & 5.0 & 4.8 & 4.6 & 4 & 4.4 & 4.2 & 4 & 3.8 & 3.6 & 3.4 & 3.2 & 1.0 & 2.8 & 2.6 & 2.4 & 2.2 & 2.0 & 1.8 & 1.6\end{array}$

Figure S45. ${ }^{1} \mathrm{H}$ NMR $\left(300.13 \mathrm{MHz}\right.$, THF- $\left.d_{8}, 298 \mathrm{~K}\right)$ spectrum of the reaction mixture of the hydration of 4-methoxyphenylacetonitrile $(\diamond)$ : formation of 4methoxyphenylacetamide $(\diamond) \cdot \bullet$ Mesitylene. 
<smiles>COc1ccc(CC(N)=O)cc1</smiles>

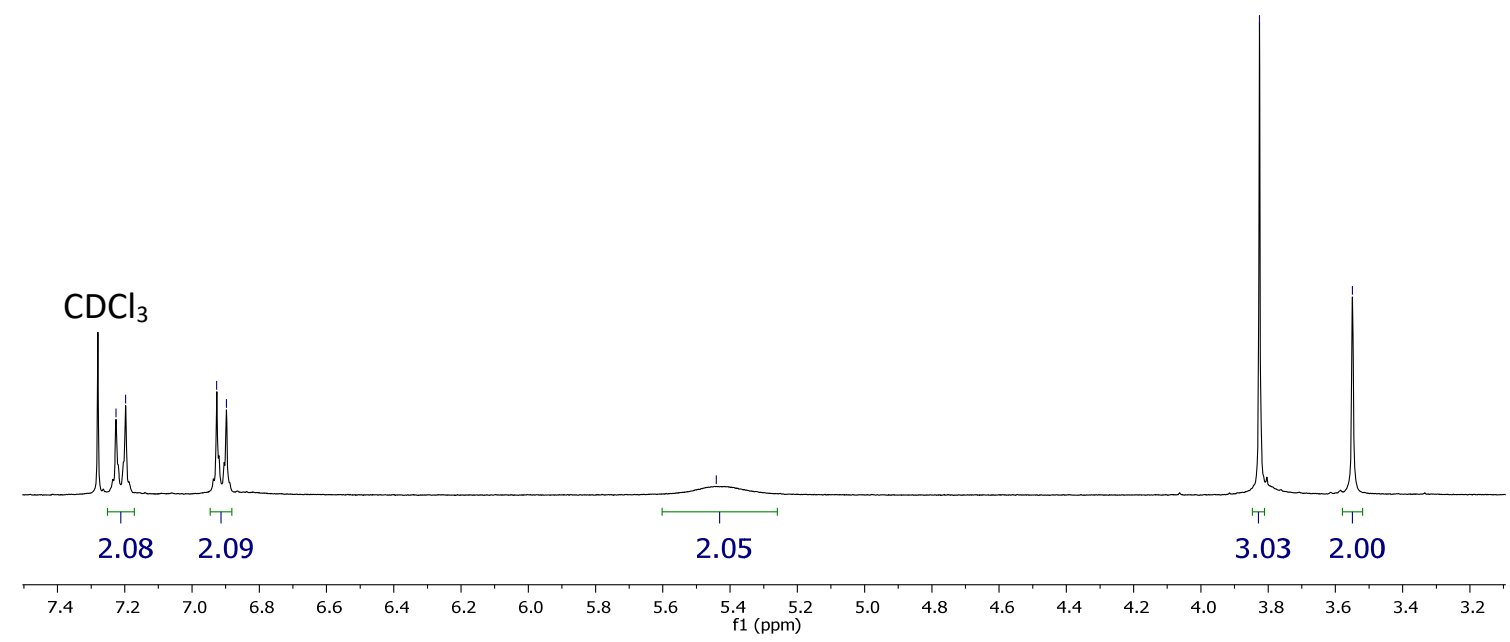

Figure S46. $\quad{ }^{1} \mathrm{H} \quad \mathrm{NMR} \quad\left(300.13 \quad \mathrm{MHz}, \mathrm{CDCl}_{3}, \quad 298 \mathrm{~K}\right) \quad$ spectrum of $4-$ methoxyphenylacetamide.
$\stackrel{\substack{n \\ \sim}}{1}$

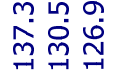

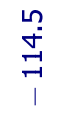

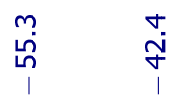

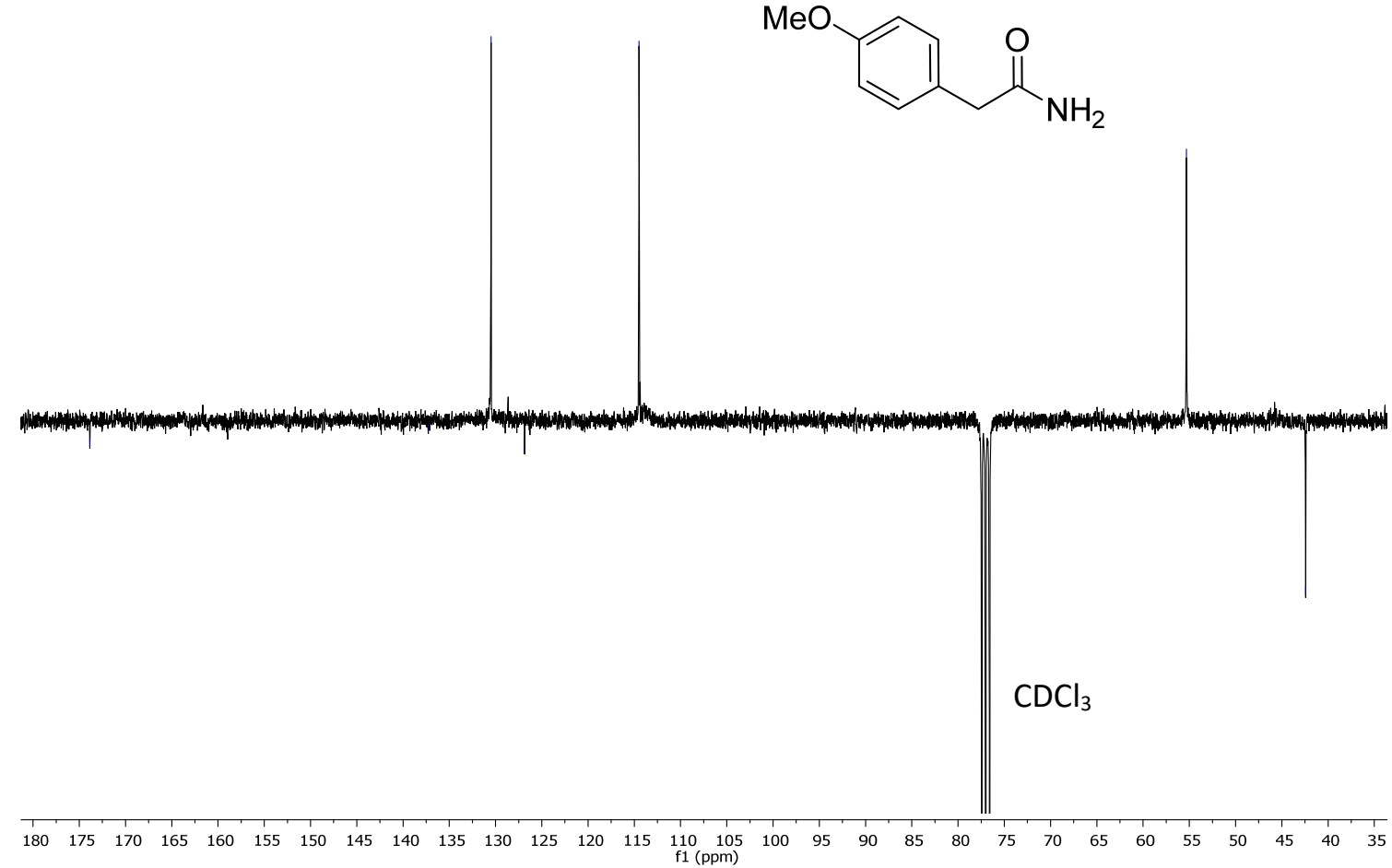

Figure S47. ${ }^{13} \mathrm{C}\left\{{ }^{1} \mathrm{H}\right\}$ APT NMR $\left(75.48 \mathrm{MHz}, \mathrm{CDCl}_{3}, 298 \mathrm{~K}\right)$ spectrum of 4methoxyphenylacetamide. 


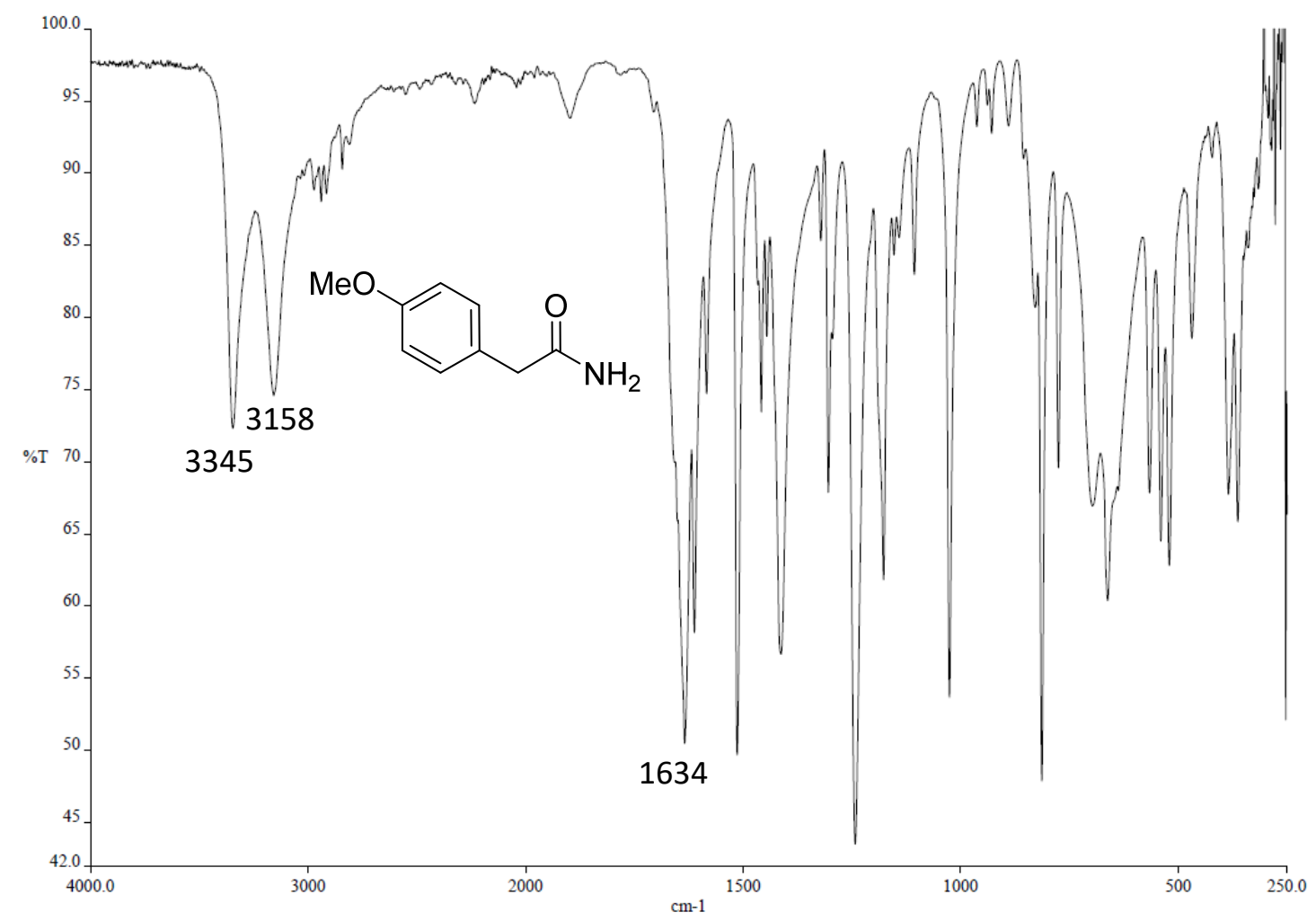

Figure S48. IR ATR spectrum of 4-methoxyphenylacetamide.

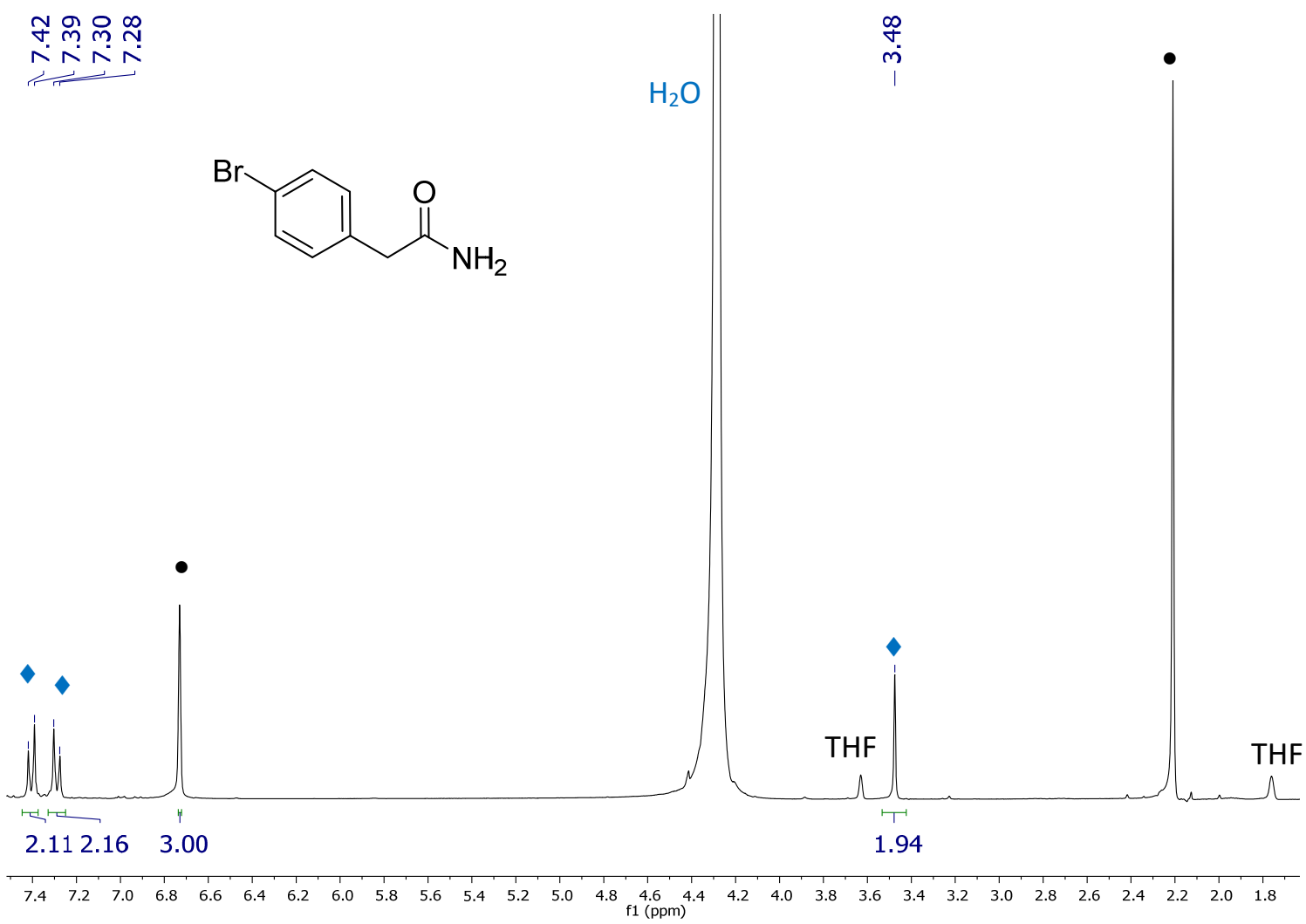

Figure S49. ${ }^{1} \mathrm{H}$ NMR $\left(300.13 \mathrm{MHz}\right.$, THF- $\left.d_{8}, 298 \mathrm{~K}\right)$ spectrum of the reaction mixture of the hydration of 4-bromoyphenylacetonitrile $(\diamond)$ : formation of 4-bromophenylacetamide $(\diamond) \cdot \bullet$ Mesitylene. 


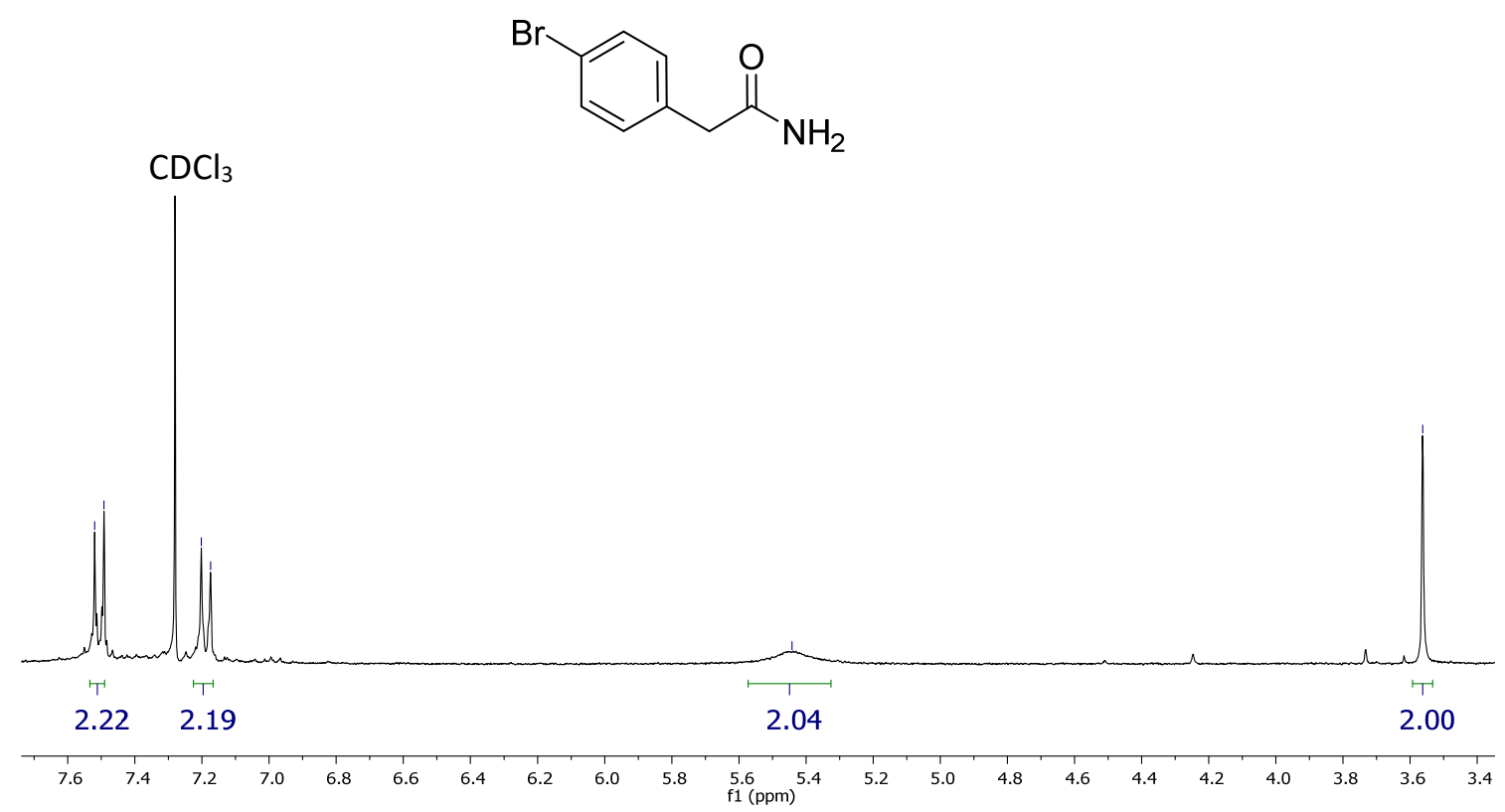

Figure S50. $\quad{ }^{1} \mathrm{H} \quad \mathrm{NMR} \quad\left(300.13 \quad \mathrm{MHz}, \quad \mathrm{CDCl}_{3}, \quad 298 \mathrm{~K}\right) \quad$ spectrum of $4-$ bromophenylacetamide.
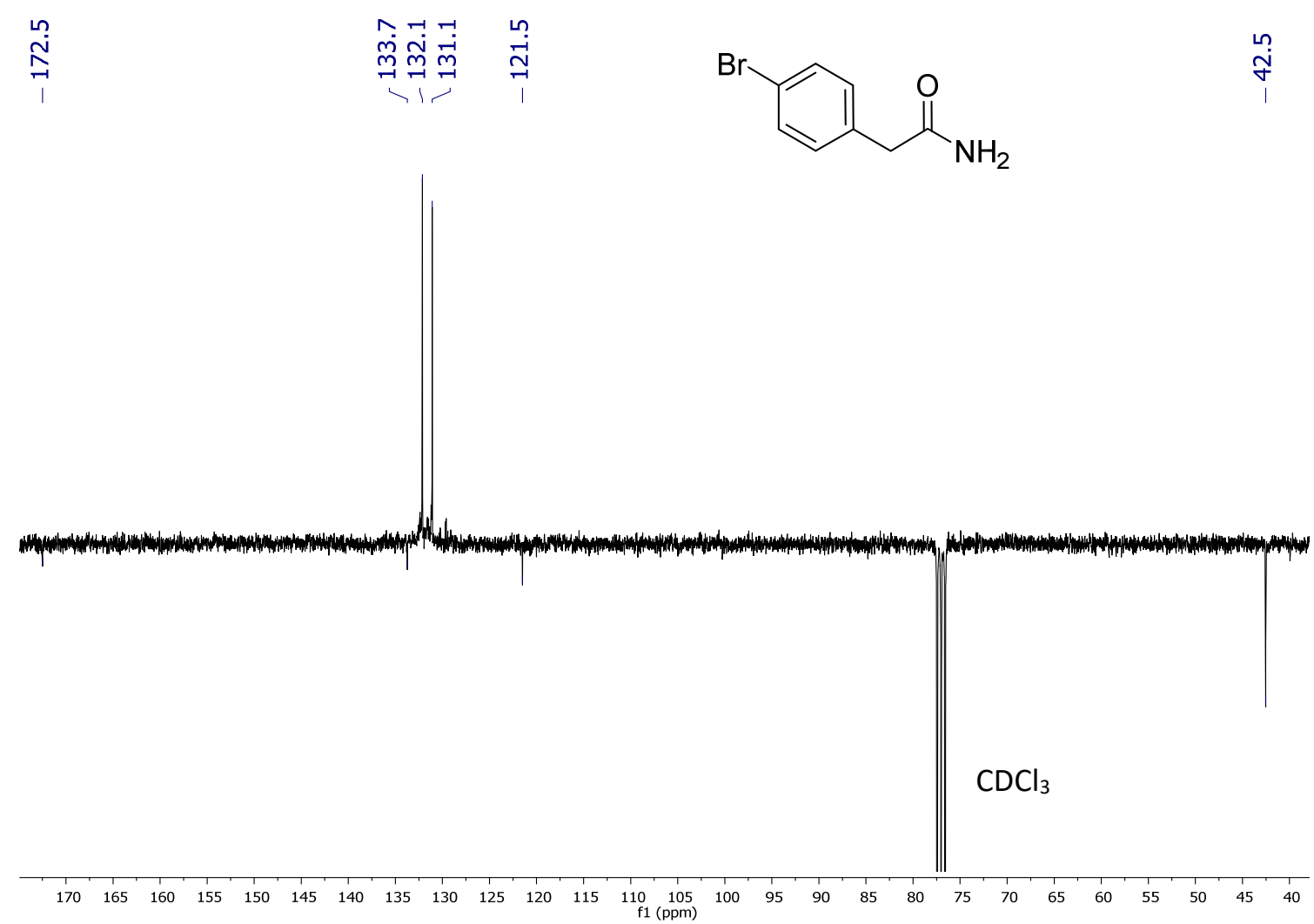

Figure S51. ${ }^{13} \mathrm{C}\left\{{ }^{1} \mathrm{H}\right\}$ APT NMR $\left(75.48 \mathrm{MHz}, \mathrm{CDCl}_{3}, 298 \mathrm{~K}\right)$ spectrum of 4bromophenylacetamide. 


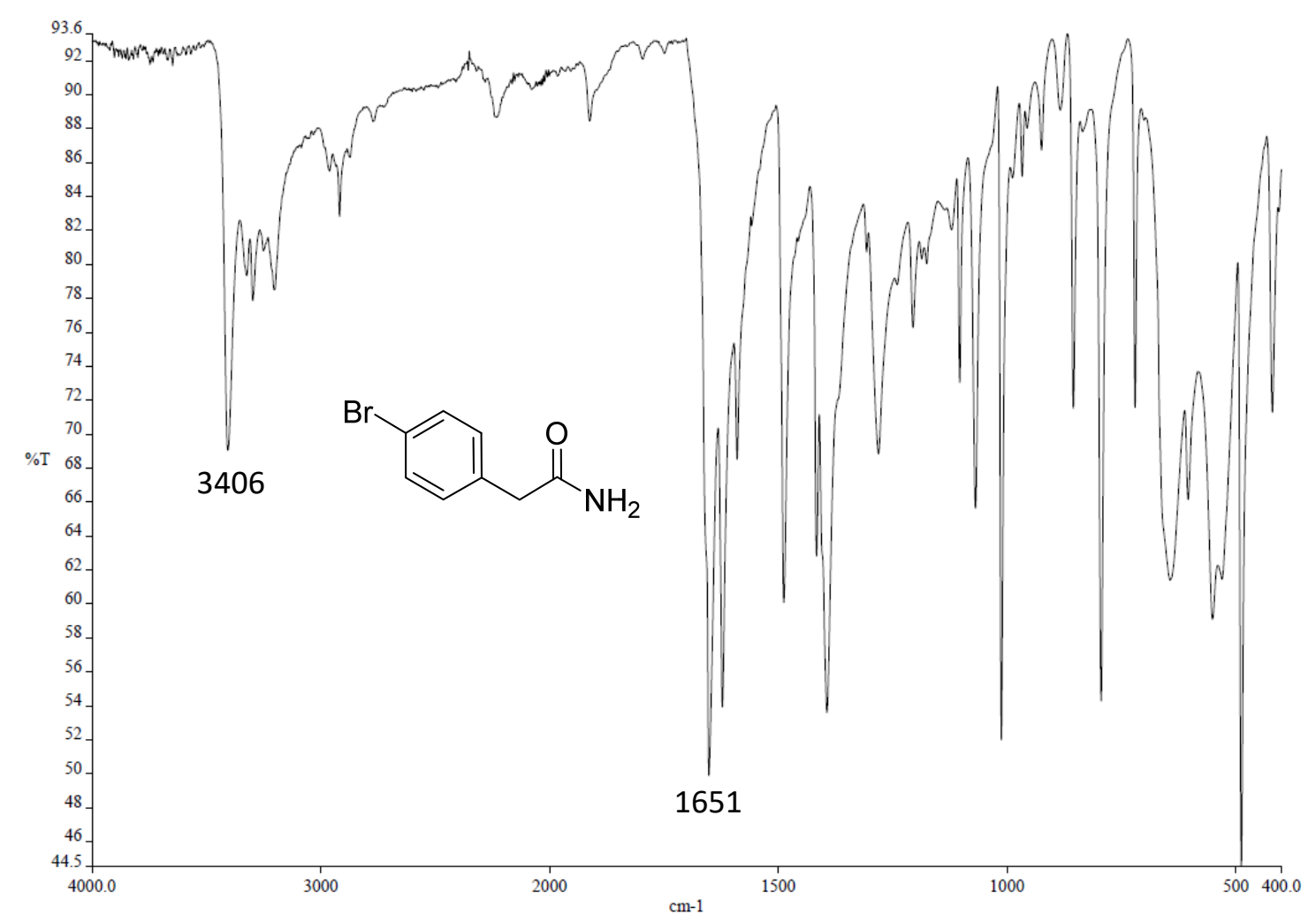

Figure S52. IR ATR spectrum of 4-bromophenylacetamide.

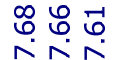
Nin

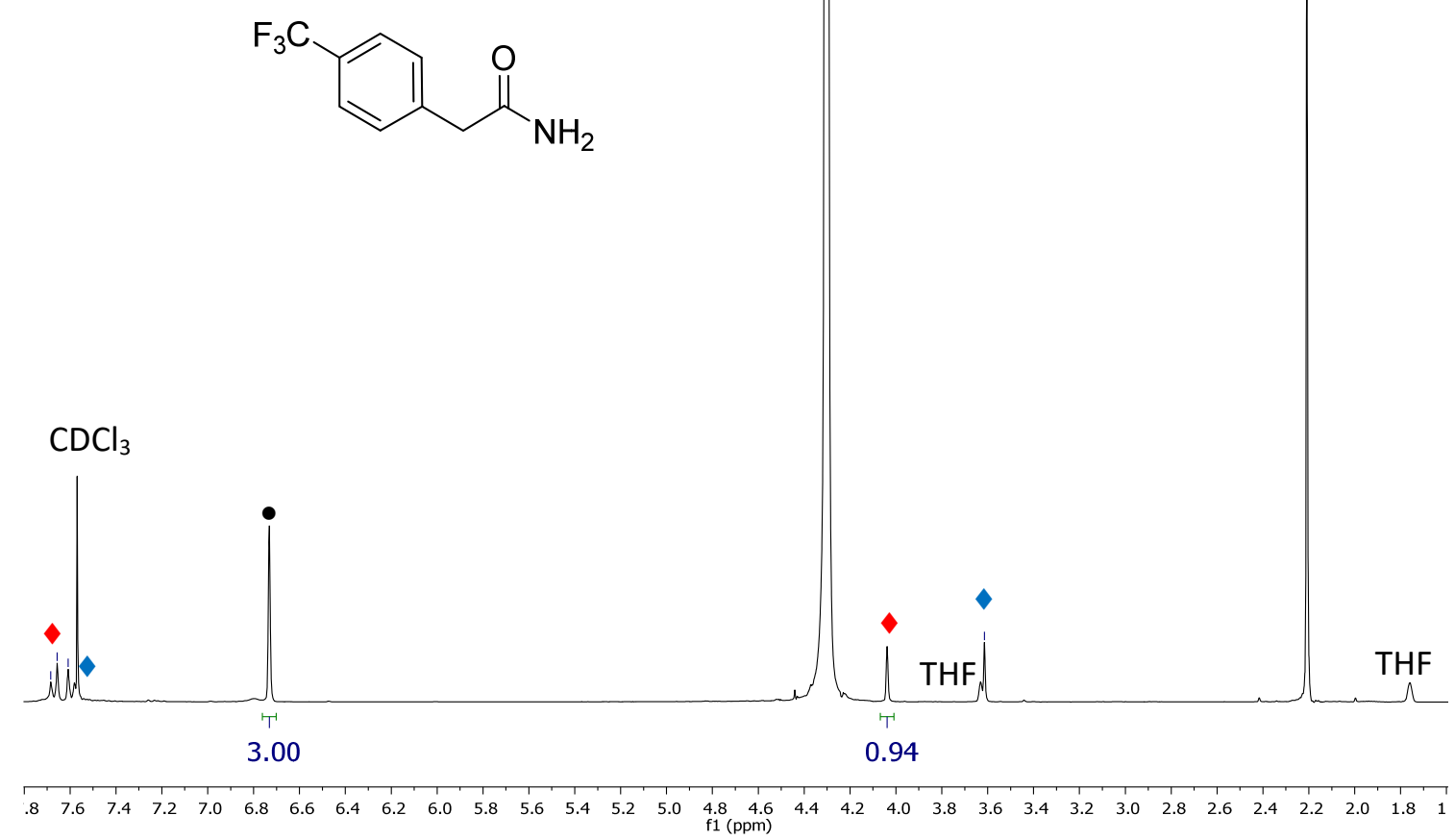

Figure S53. ${ }^{1} \mathrm{H}$ NMR $(300.13 \mathrm{MHz}$, THF- $d 8,298 \mathrm{~K})$ spectrum of the reaction mixture of the hydration of 4-(trifluoromethyl)phenylacetonitrile $(\diamond)$ : formation of 4(trifluoromethyl)phenylacetamide $(\diamond)$. $\bullet$ Mesitylene. 
<smiles>NC(=O)Cc1ccc(C(F)(F)F)cc1</smiles>

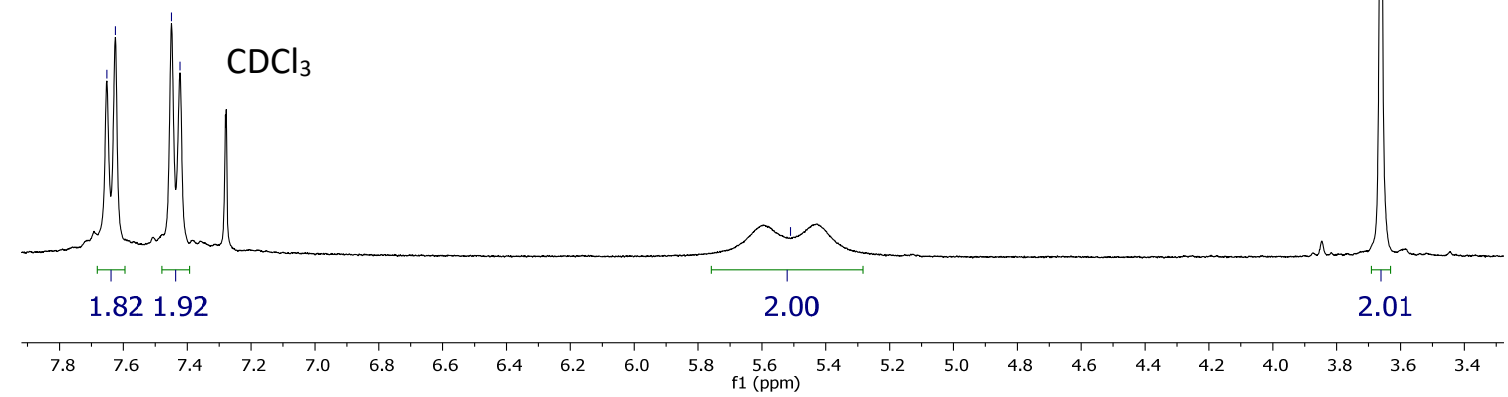

Figure S54. ${ }^{1} \mathrm{H} \quad \mathrm{NMR} \quad\left(300.13 \quad \mathrm{MHz}, \quad \mathrm{CDCl}_{3}, \quad 298 \quad \mathrm{~K}\right) \quad$ spectrum of $4-$ (trifluoromethyl)phenylacetamide.
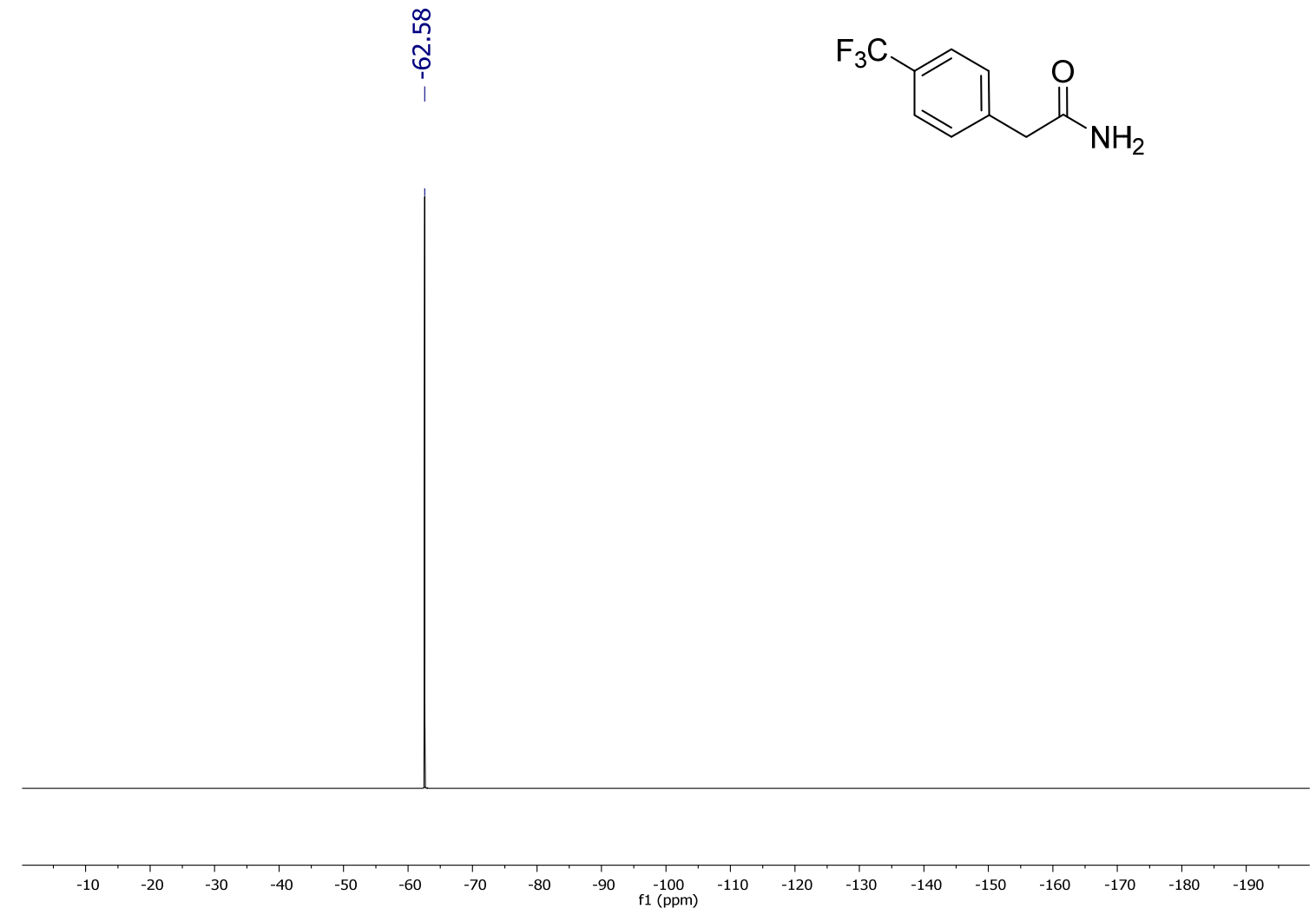

Figure S55. ${ }^{19} \mathrm{~F} \quad \mathrm{NMR} \quad\left(376.49 \mathrm{MHz}, \mathrm{CDCl}_{3}, \quad 298 \mathrm{~K}\right)$ spectrum of 4(trifluoromethyl)phenylacetamide. 


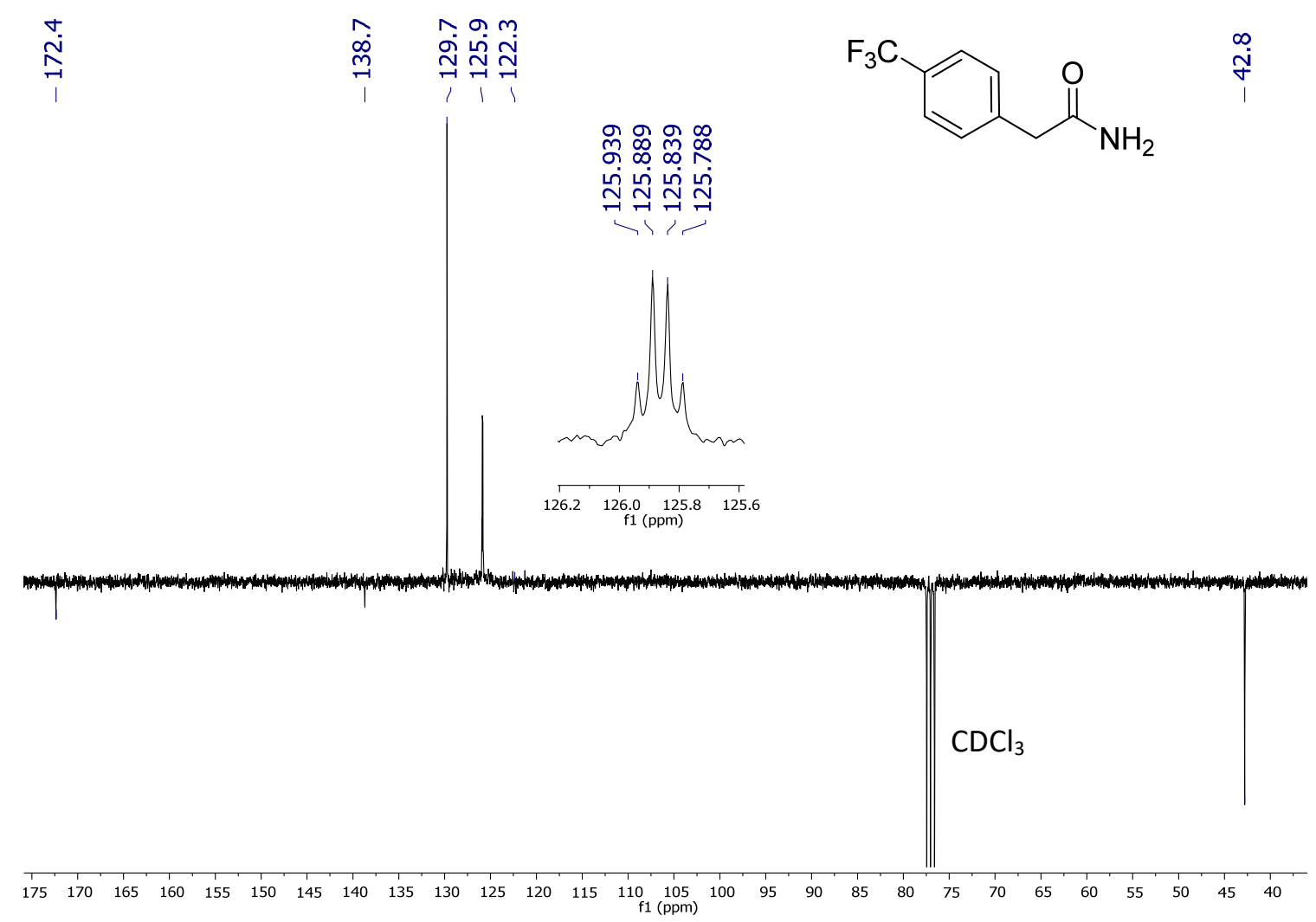

Figure S56. ${ }^{13} \mathrm{C}\left\{{ }^{1} \mathrm{H}\right\}$ APT NMR (75.48 $\left.\mathrm{MHz}, \mathrm{CDCl}_{3}, 298 \mathrm{~K}\right)$ spectrum of 4(trifluoromethyl)phenylacetamide.

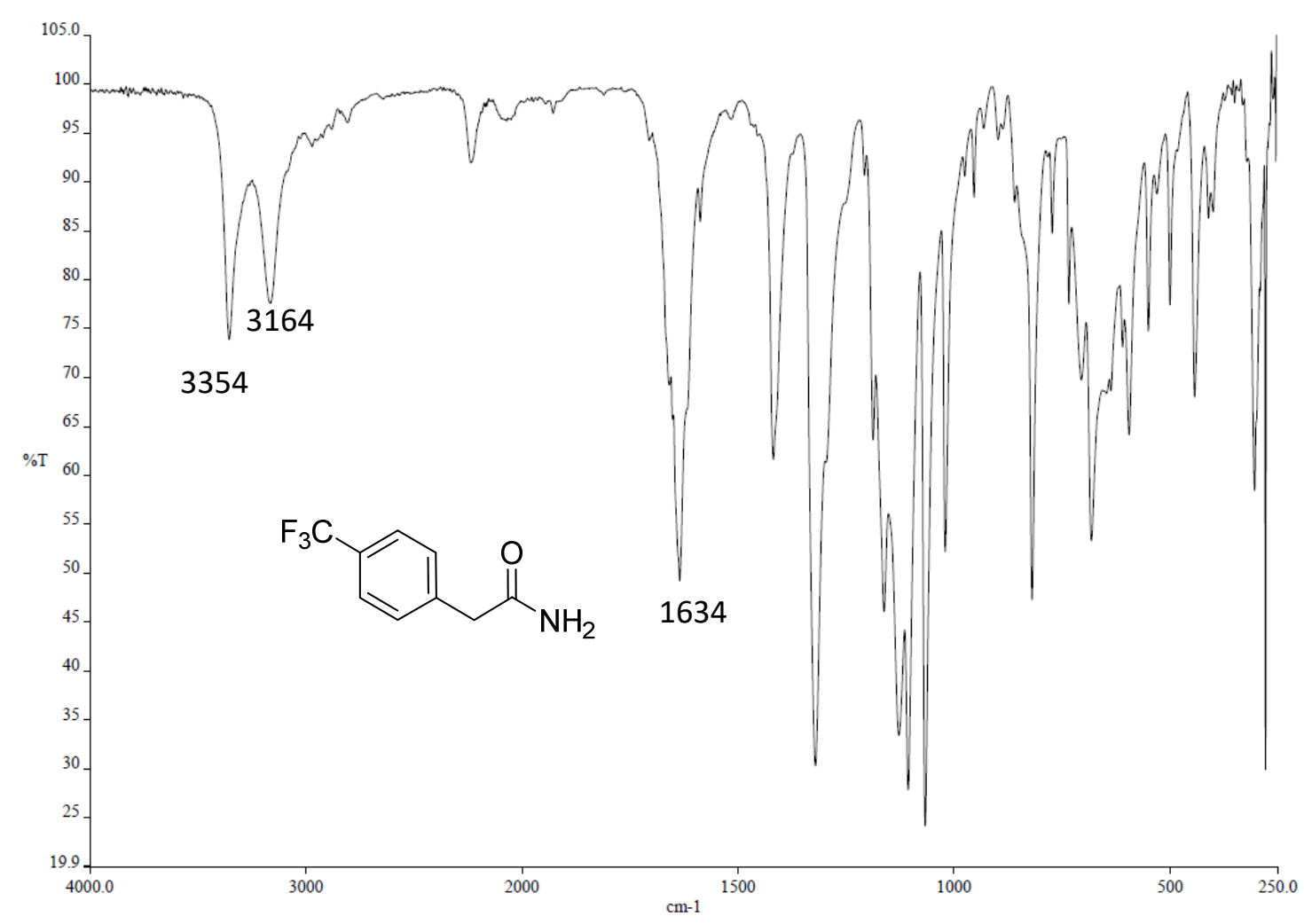

Figure S57. IR ATR spectrum of 4-(trifluoromethyl)phenylacetamide. 
<smiles>COC(=O)c1ccc(CC(N)=O)cc1</smiles>

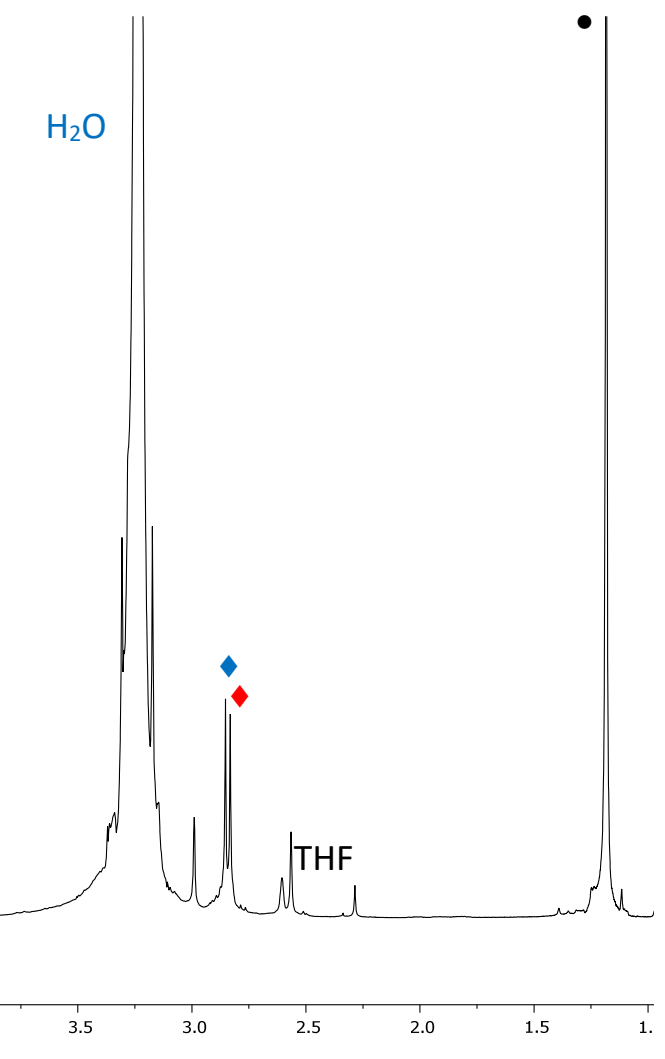

Figure S58. ${ }^{1} \mathrm{H}$ NMR $(300.13 \mathrm{MHz}$, THF- $d 8,298 \mathrm{~K})$ spectrum of the reaction mixture of the hydration of methyl-4-(cyanomethyl)benzoate $(\diamond)$ : formation of methyl-4-(2-amino2-oxoethyl)benzoate $(\diamond)$. $\bullet$ Mesitylene.

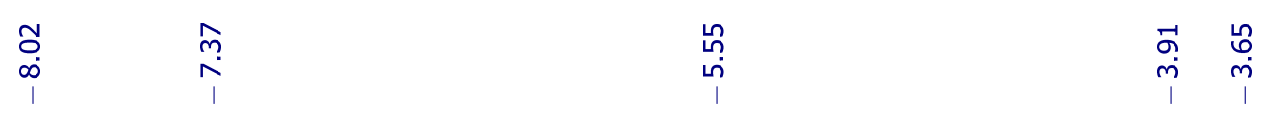<smiles>COC(=O)c1ccc(CC(N)=O)cc1</smiles>

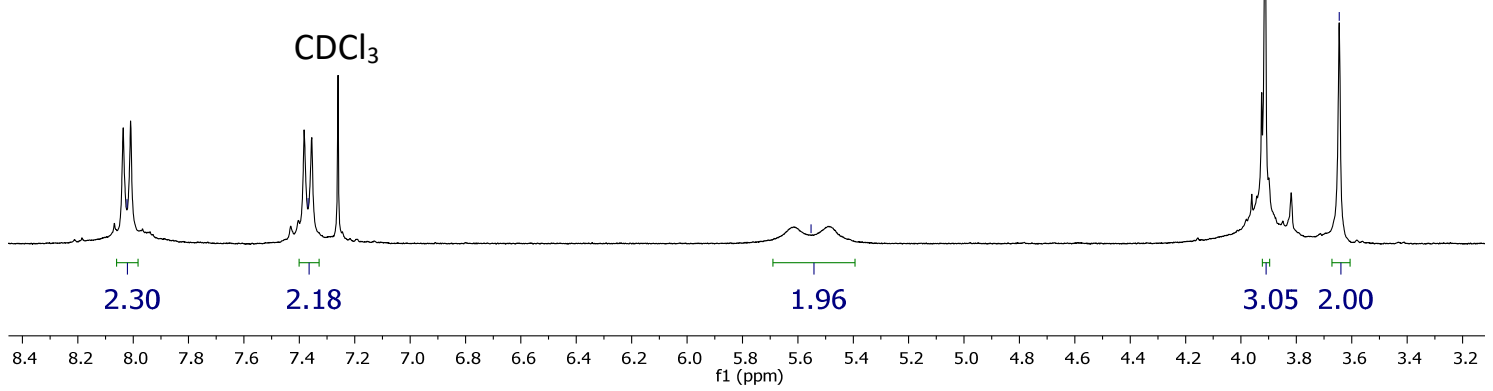

Figure S59. ${ }^{1} \mathrm{H}$ NMR $\left(300.13 \mathrm{MHz}, \mathrm{CDCl}_{3}, 298 \mathrm{~K}\right)$ spectrum of methyl-4-(2-amino-2oxoethyl)benzoate. 


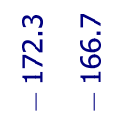

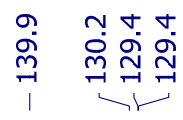
กั่

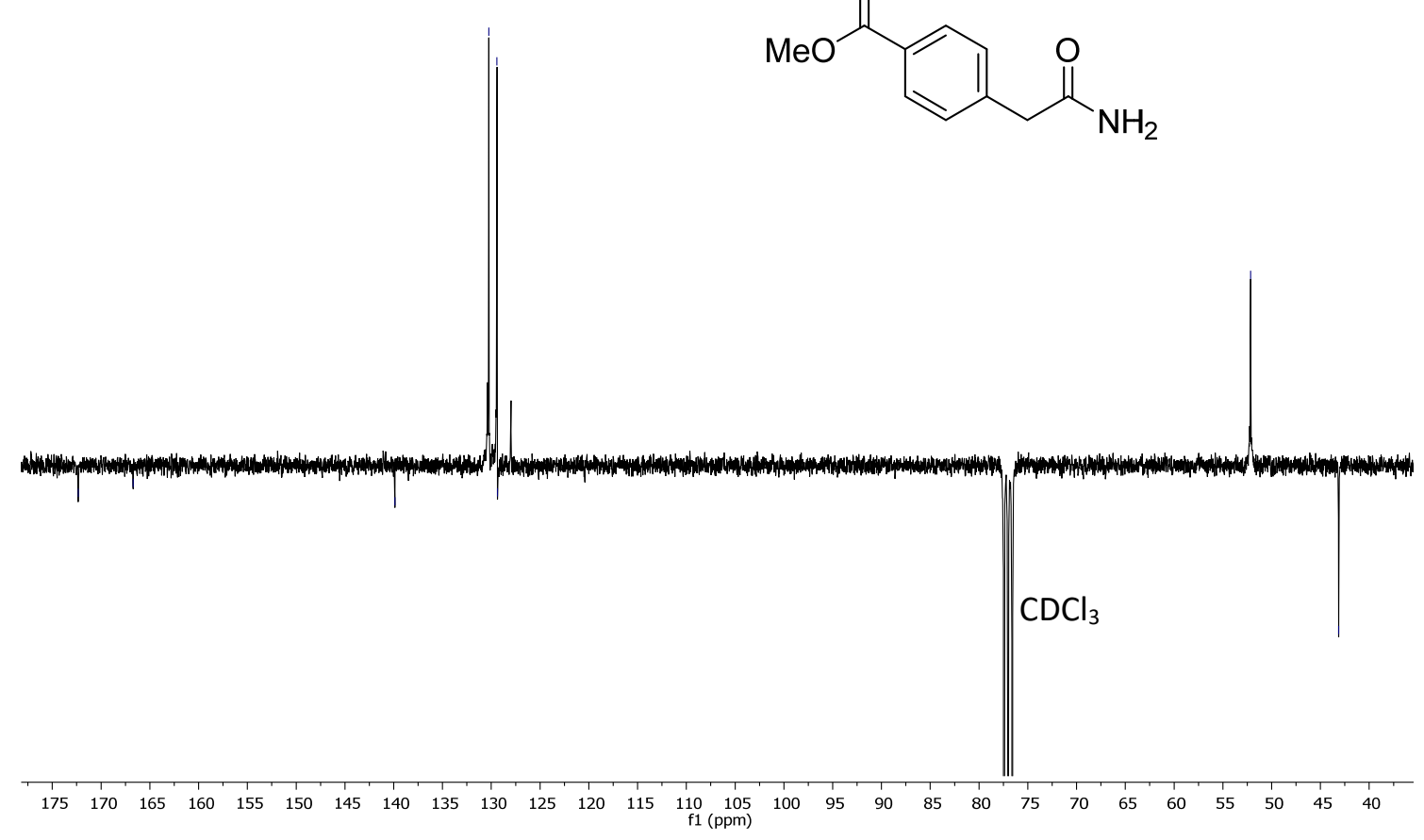

Figure S60. ${ }^{13} \mathrm{C}\left\{{ }^{1} \mathrm{H}\right\}$ APT NMR (75.48 MHz, $\left.\mathrm{CDCl}_{3}, 298 \mathrm{~K}\right)$ spectrum of methyl-4-(2amino-2-oxoethyl)benzoate.

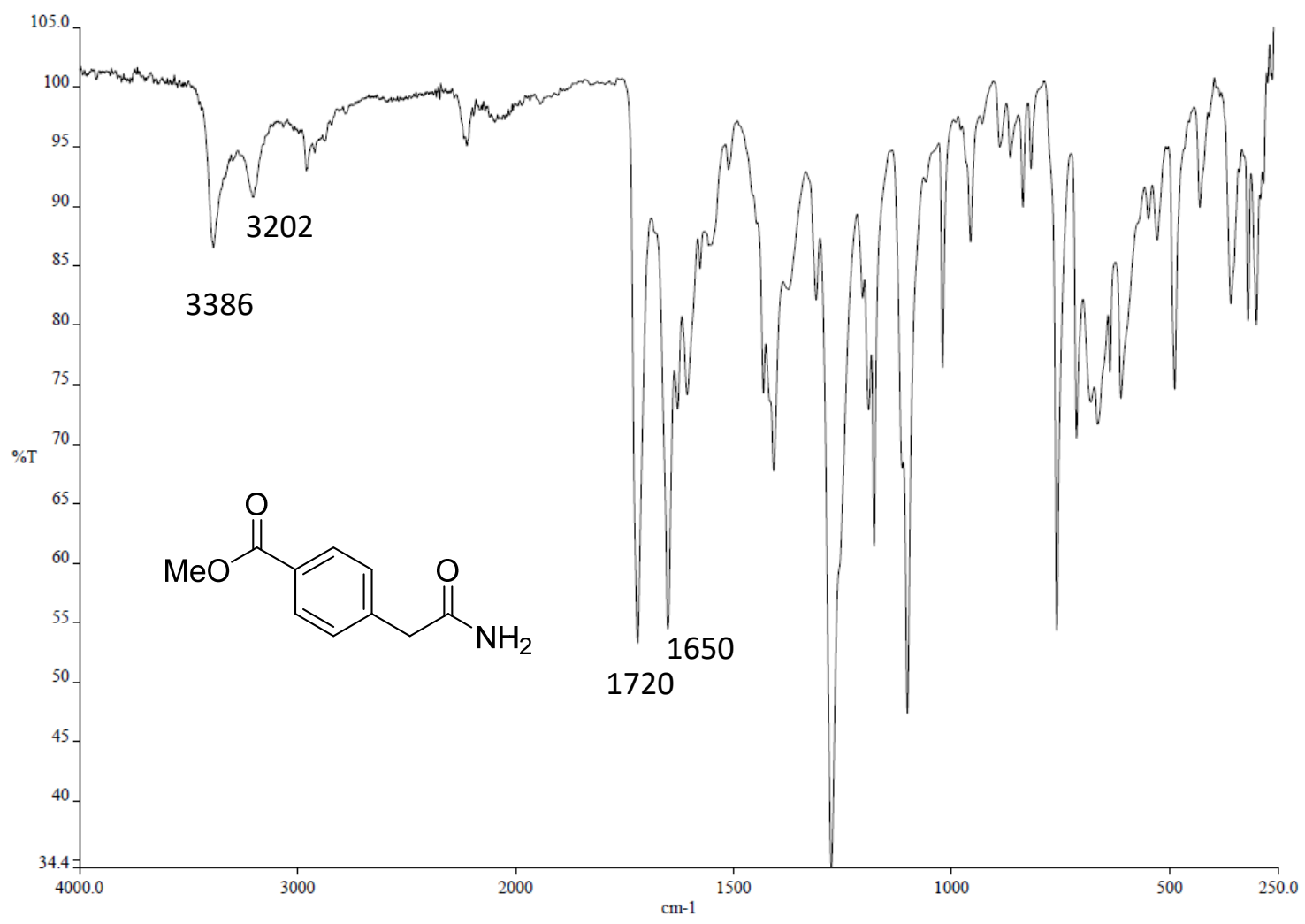

Figure S61. IR ATR spectrum of methyl-4-(2-amino-2-oxoethyl)benzoate. 


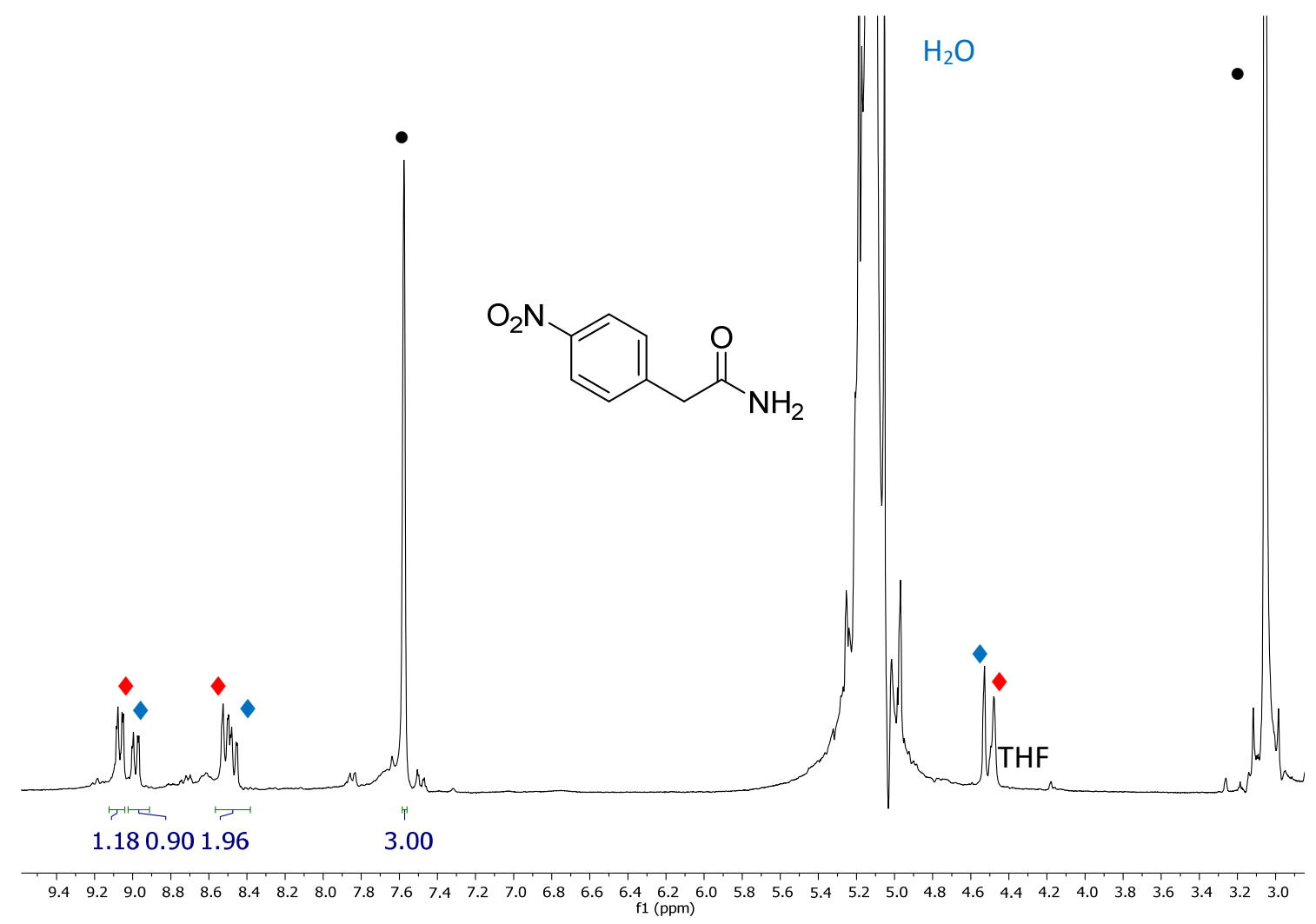

Figure S62. ${ }^{1} \mathrm{H}$ NMR $\left(300.13 \mathrm{MHz}, \mathrm{THF}-d_{8}, 298 \mathrm{~K}\right)$ spectrum of the reaction mixture of the hydration of 4-nitrophenylacetonitrile $(\diamond)$ : formation of 4-nitrophenylacetamide $(\diamond)$. - Mesitylene.

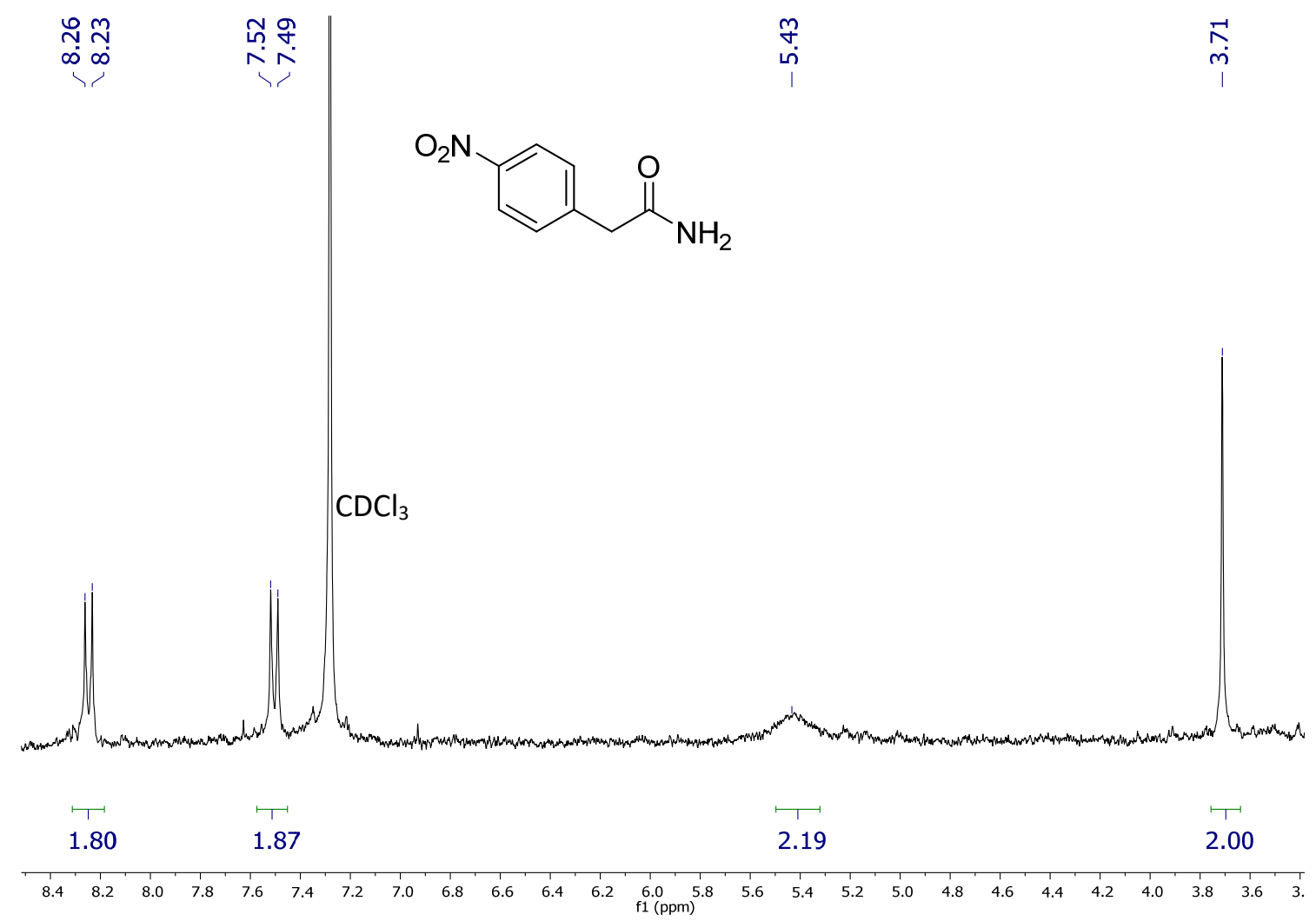

Figure S63. ${ }^{1} \mathrm{H}$ NMR $\left(300.13 \mathrm{MHz}, \mathrm{CDCl}_{3}, 298 \mathrm{~K}\right)$ spectrum of 4-nitrophenylacetamide. 


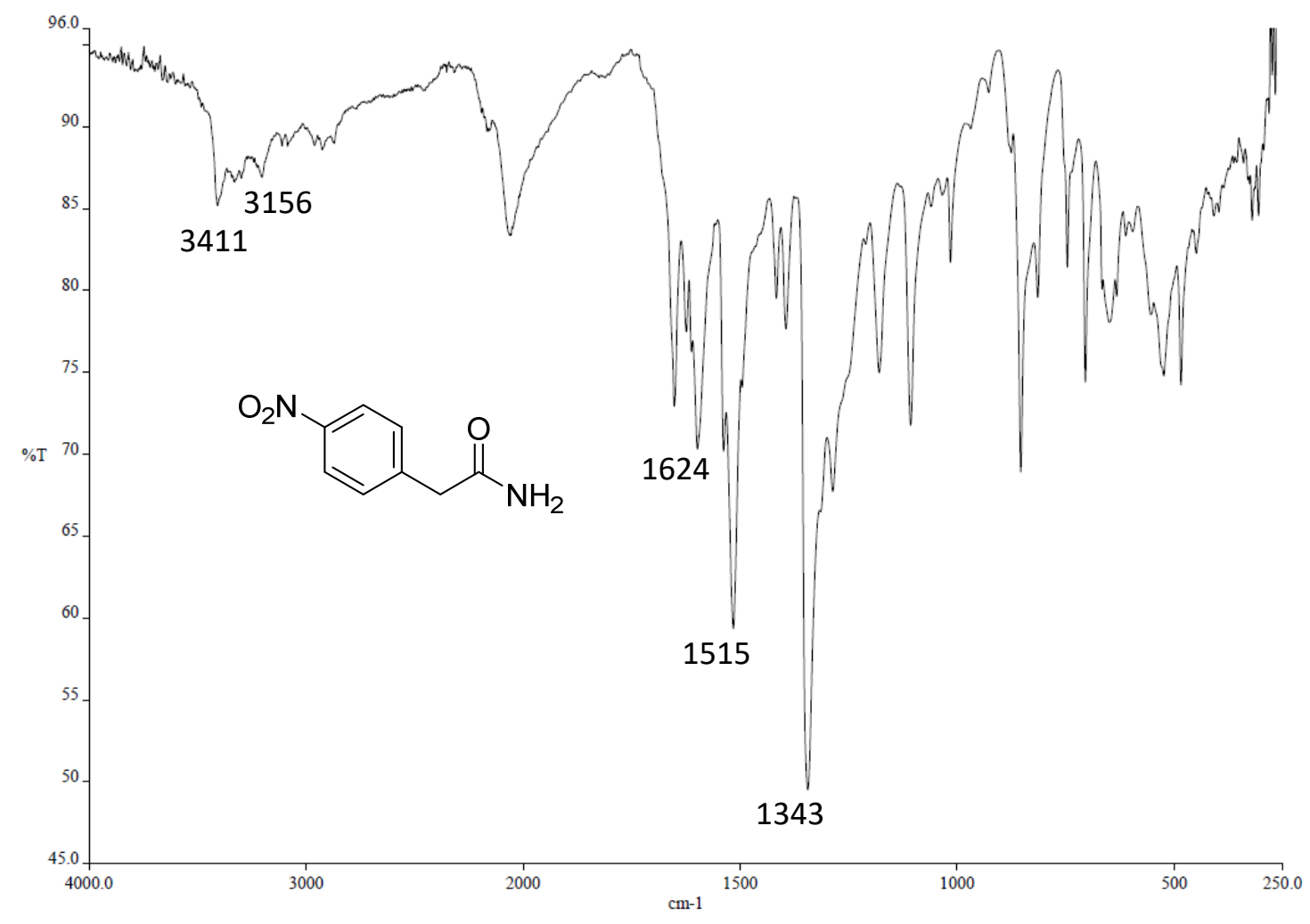

Figure S64. IR ATR spectrum of 4-nitrophenylacetamide.

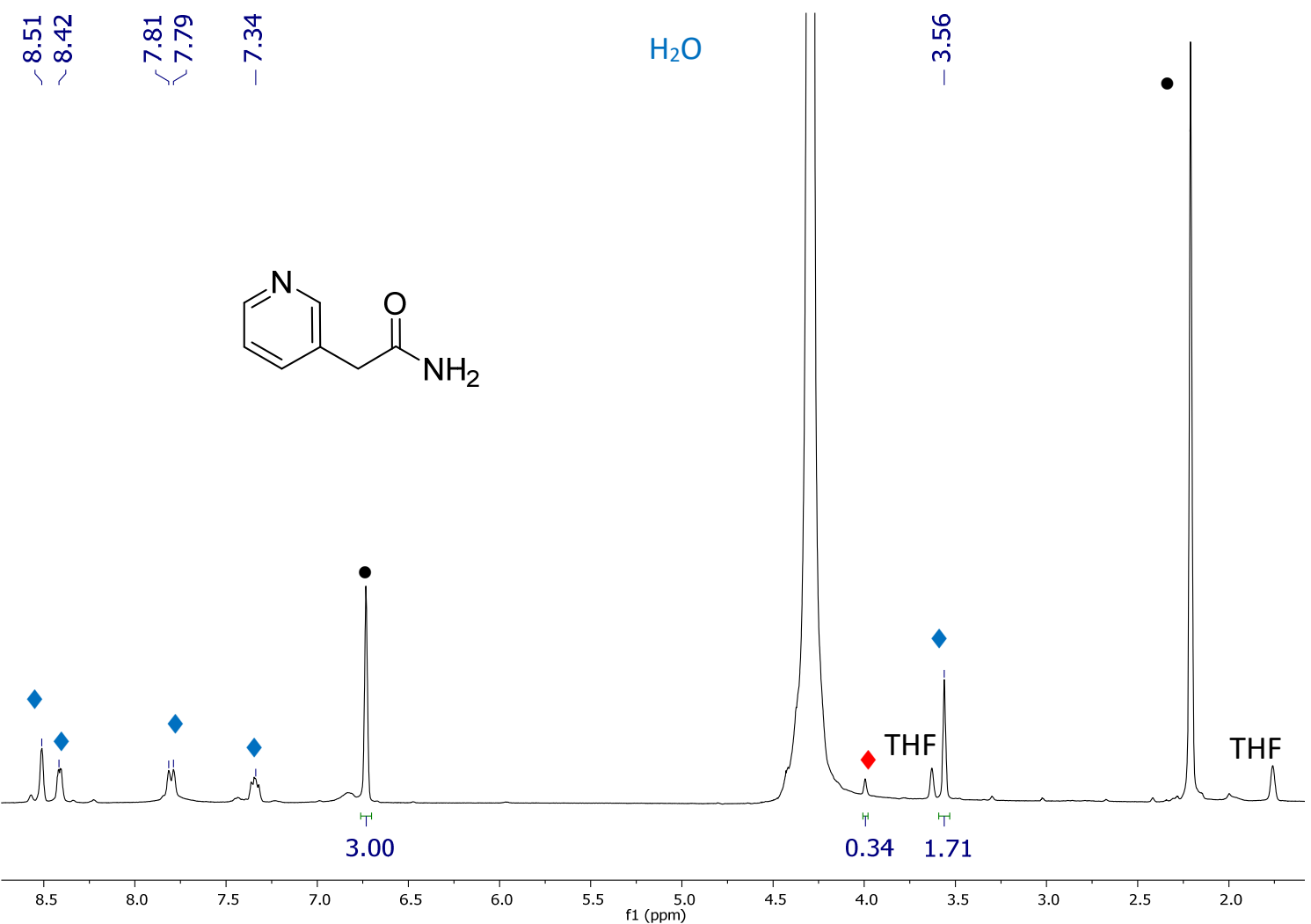

Figure S65. ${ }^{1} \mathrm{H}$ NMR $(300.13 \mathrm{MHz}$, THF- $d 8,298 \mathrm{~K})$ spectrum of the reaction mixture of the hydration of (pyridin-3-yl)acetonitrile $(\diamond)$ : formation of (pyridin-3-yl)acetamide $(\diamond)$.

- Mesitylene. 
<smiles>NC(=O)Cc1cccnc1</smiles>

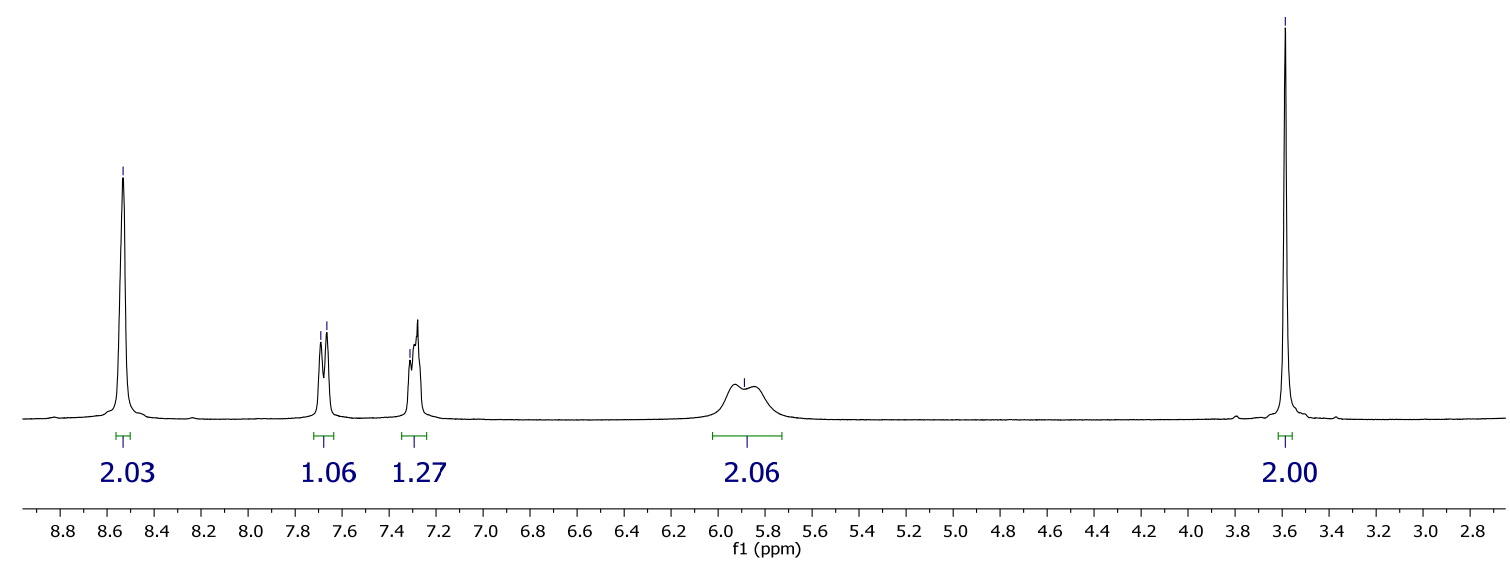

Figure S66. ${ }^{1} \mathrm{H}$ NMR (300.13 MHz, $\mathrm{CDCl}_{3}, 298 \mathrm{~K}$ ) spectrum of (pyridin-3-yl)acetamide.

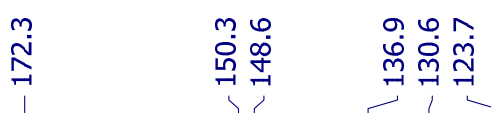

$\stackrel{\circ}{\circ}$<smiles>NC(=O)Cc1cccnc1</smiles>

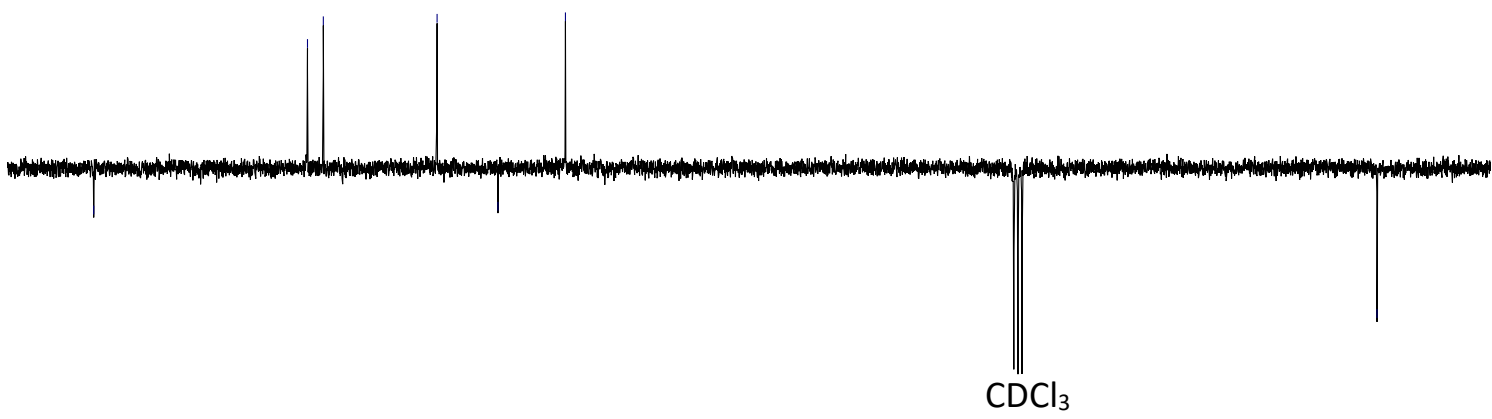

$\begin{array}{llllllllllllllllllllllllllllllllll}180 & 175 & 170 & 165 & 160 & 155 & 150 & 145 & 140 & 135 & 130 & 125 & 120 & 115 & 110 & 105 & 100 & 95 & 90 & 85 & 80 & 75 & 70 & 65 & 60 & 55 & 50 & 45 & 40 & 35 & 30\end{array}$ Figure S67. ${ }^{13} \mathrm{C}\left\{{ }^{1} \mathrm{H}\right\}$ APT NMR $\left(75.48 \mathrm{MHz}, \mathrm{CDCl}_{3}, 298 \mathrm{~K}\right)$ spectrum of (pyridin-3yl)acetamide. 


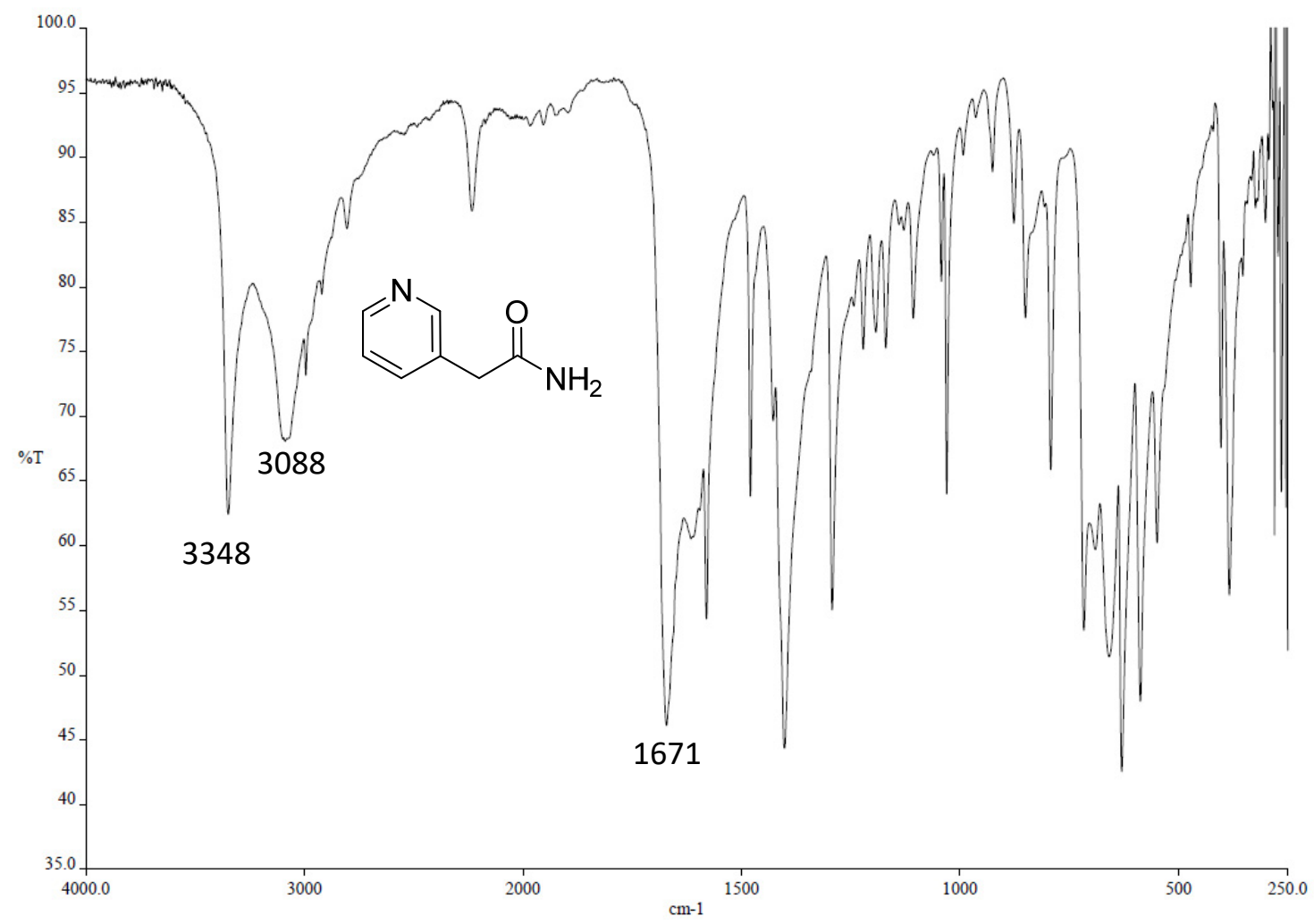

Figure S68. IR ATR spectrum of 2-(pyridin-3-yl)acetamide.

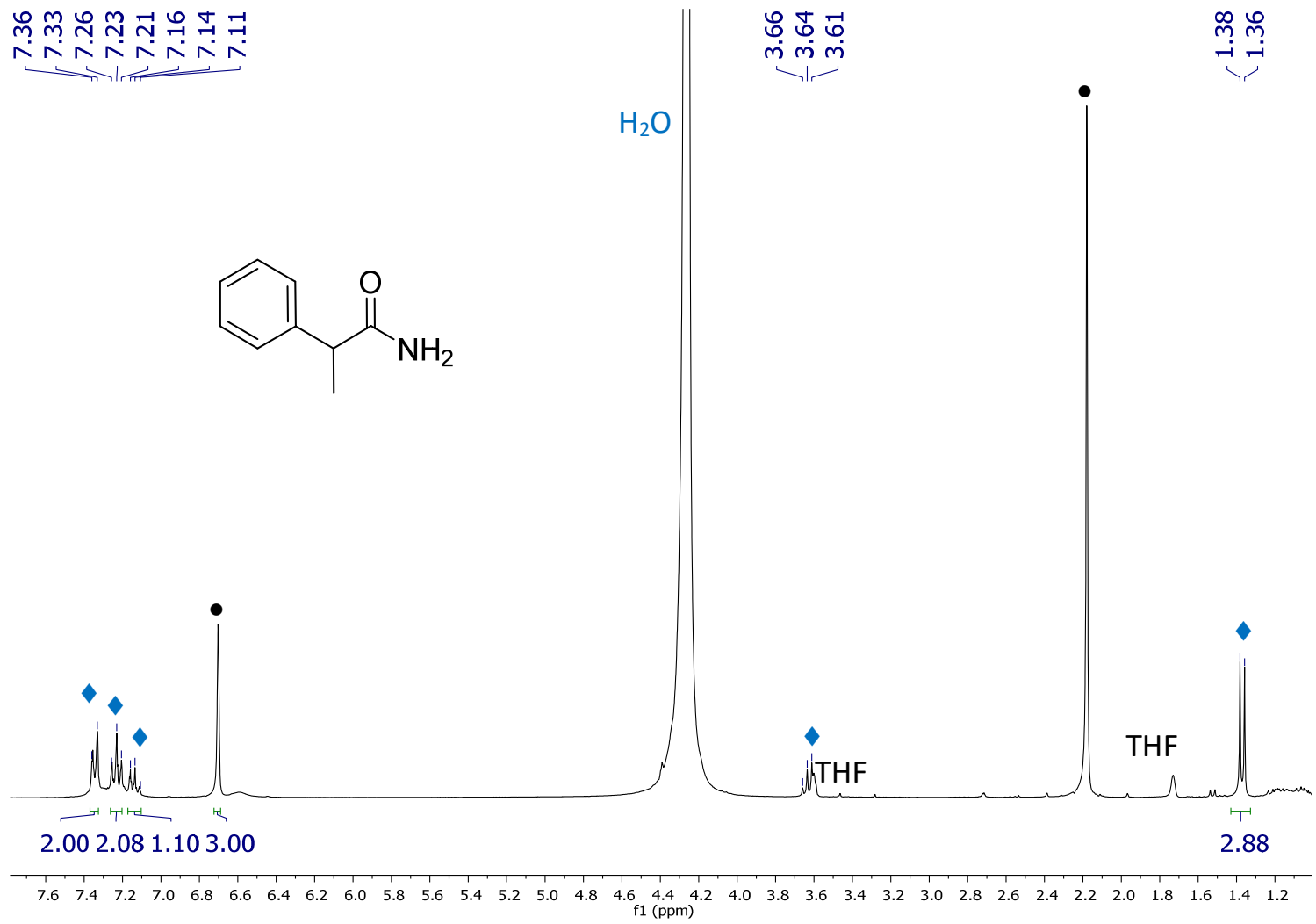

Figure S69. ${ }^{1} \mathrm{H}$ NMR $(300.13 \mathrm{MHz}$, THF- $d 8,298 \mathrm{~K})$ spectrum of the reaction mixture of the hydration of 2-phenylpropionitrile $(\diamond)$ : formation of 2-phenylpropanamide $(\diamond)$. $\bullet$ Mesitylene. 
<smiles>CC(C(N)=O)c1ccccc1</smiles>

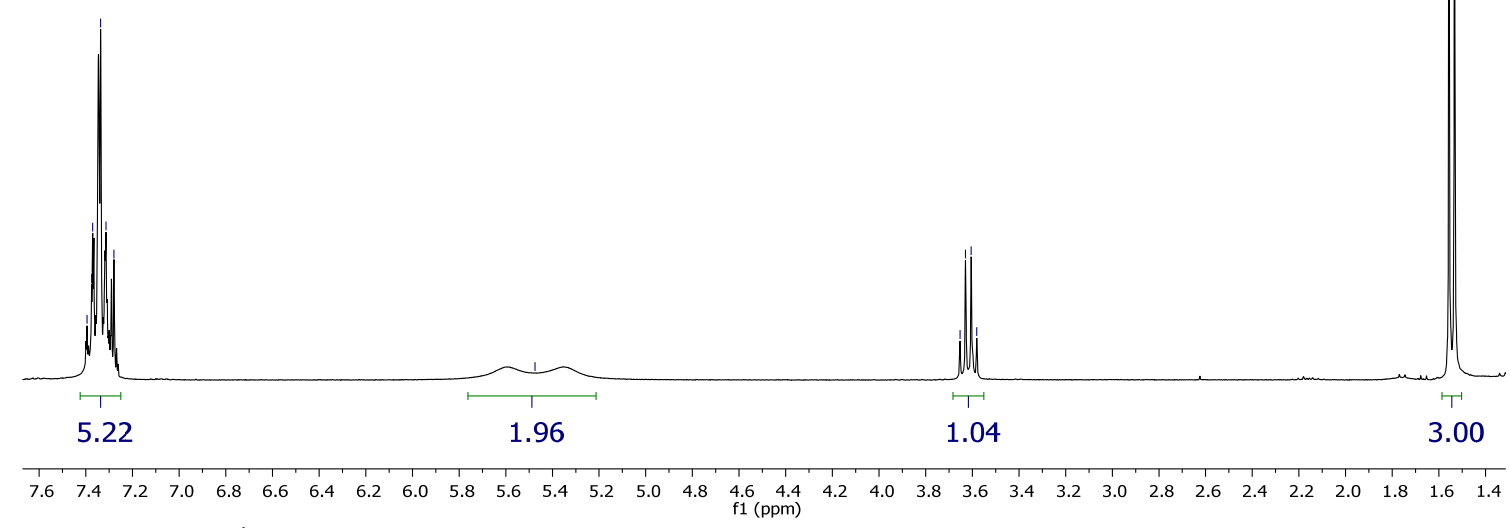

Figure S70. ${ }^{1} \mathrm{H}$ NMR (300.13 MHz, $\left.\mathrm{CDCl}_{3}, 298 \mathrm{~K}\right)$ spectrum of 2-phenylpropanamide.
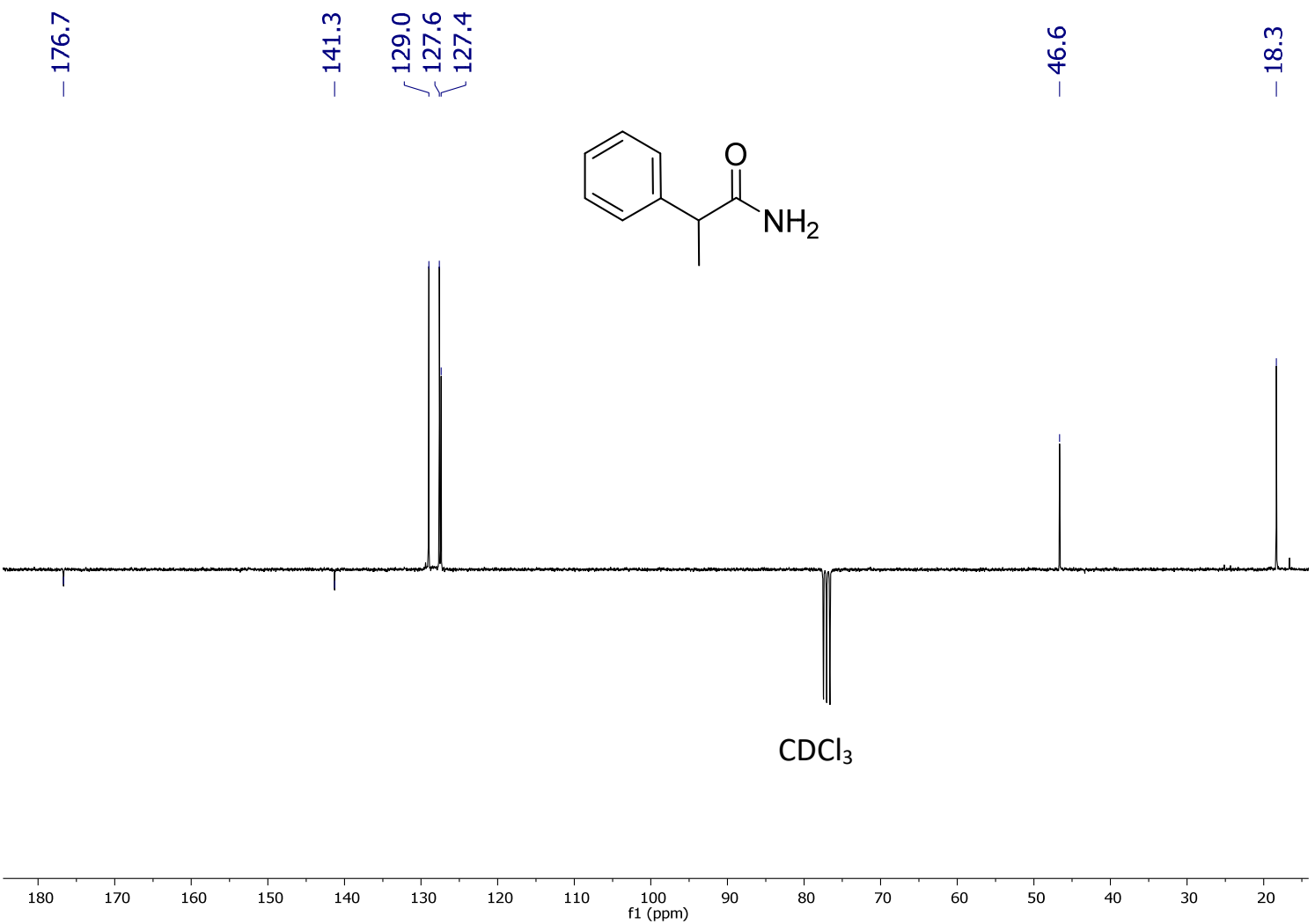

Figure S71. ${ }^{13} \mathrm{C}\left\{{ }^{1} \mathrm{H}\right\}$ APT $\mathrm{NMR}\left(75.48 \mathrm{MHz}, \mathrm{CDCl}_{3}, 298 \mathrm{~K}\right)$ spectrum of 2phenylpropanamide. 


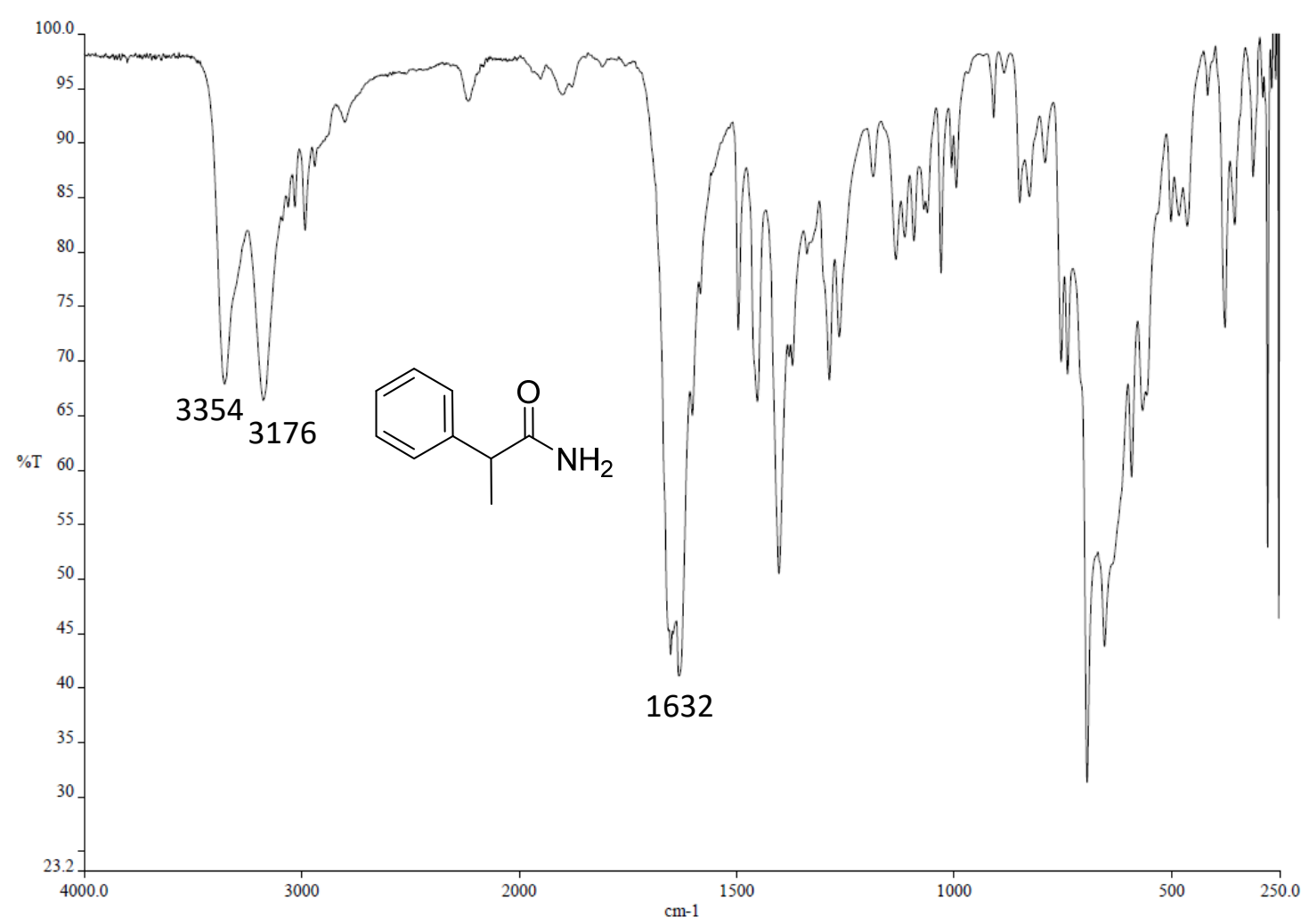

Figure S72. IR ATR spectrum of 2-phenylpropanamide.

กุ๊ก๊ำ

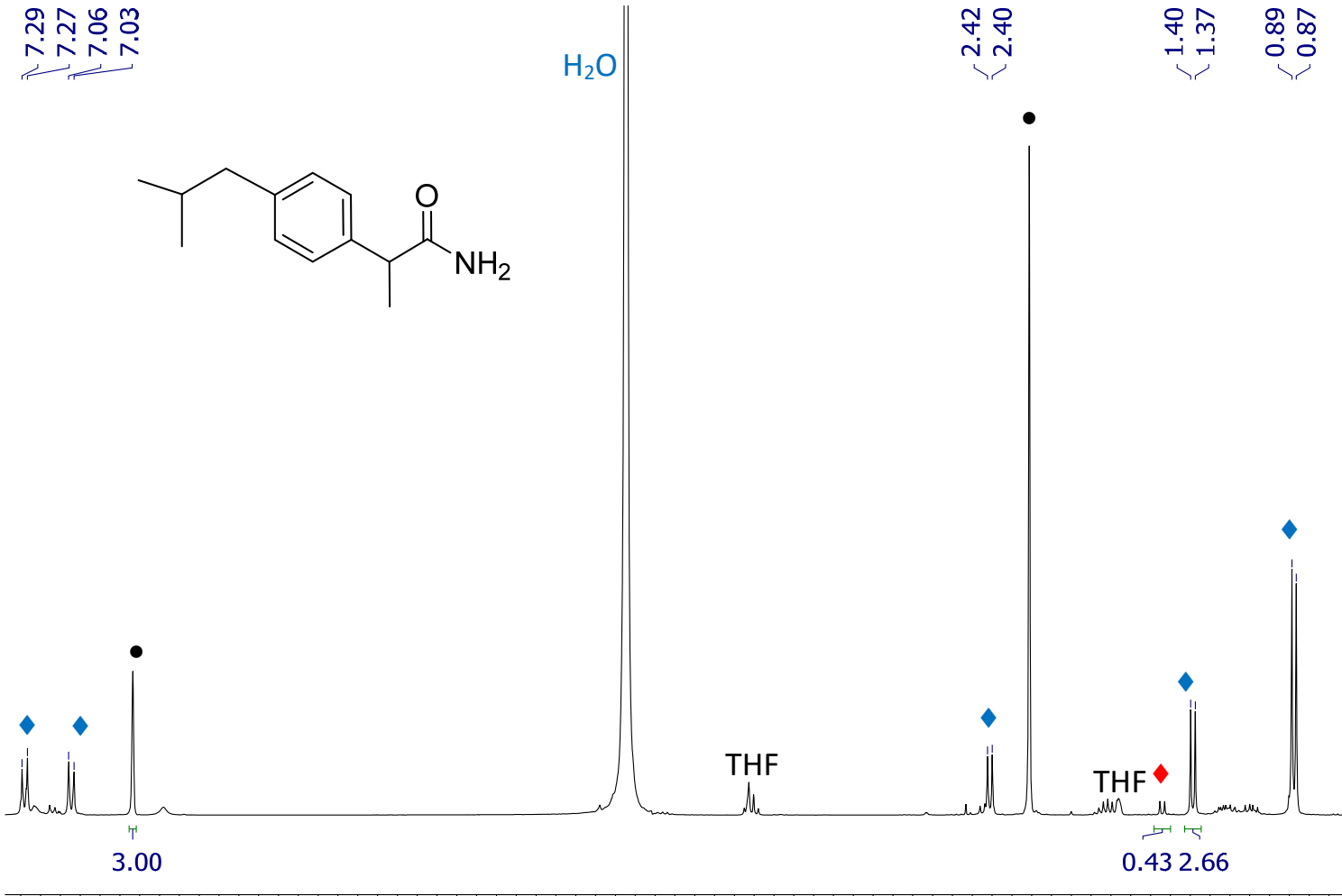

$\begin{array}{lllllllllllllllllllllllllllllllllllllllllll}7.2 & 7.0 & 6.8 & 6.6 & 6.4 & 6.2 & 6.0 & 5.8 & 5.6 & 5.4 & 5.2 & 5.0 & 4.8 & 4.6 & 4.4 & 4.2 & 4.0 & 3.8 & 3.6 & 3.4 & 3.2 & 3.0 & 2.8 & 2.6 & 2.4 & 2.2 & 2.0 & 1.8 & 1.6 & 1.4 & 1.2 & 1.0 & 0.8\end{array}$

Figure S73. ${ }^{1} \mathrm{H}$ NMR $(300.13 \mathrm{MHz}$, THF- $d 8,298 \mathrm{~K})$ spectrum of the reaction mixture of the hydration of 2-(3-isobutylphenyl)propanenitrile $(\diamond)$ : formation of 2-(3isobutylphenyl)propanamide $(\diamond) \cdot \bullet$ Mesitylene 
$\stackrel{\substack{1 \\ \sim}}{\sim}$
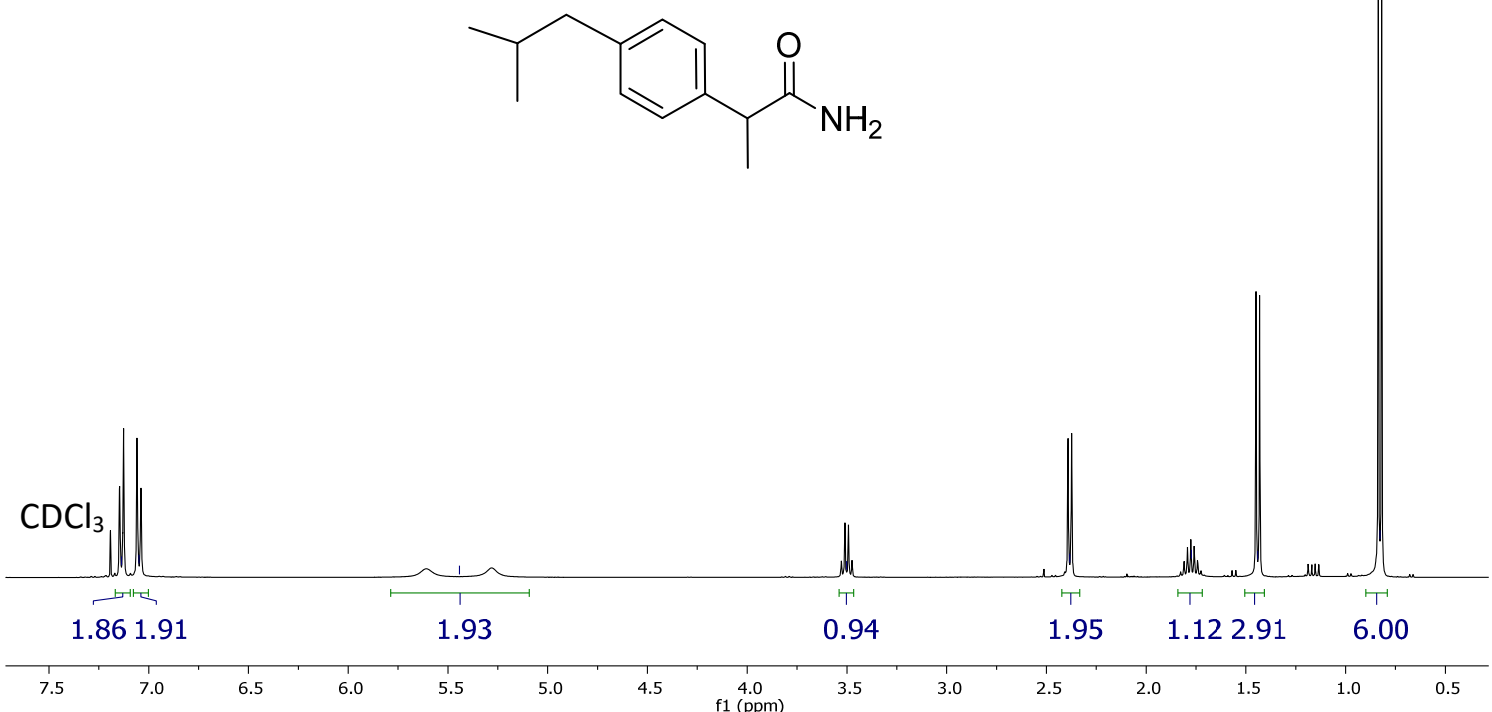

Figure S74. ${ }^{1} \mathrm{H}$ NMR (400.16 $\left.\mathrm{MHz}, \mathrm{CDCl}_{3}, 298 \mathrm{~K}\right)$ spectrum of 2-(3isobutylphenyl)propanamide.

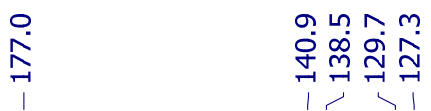

mơ

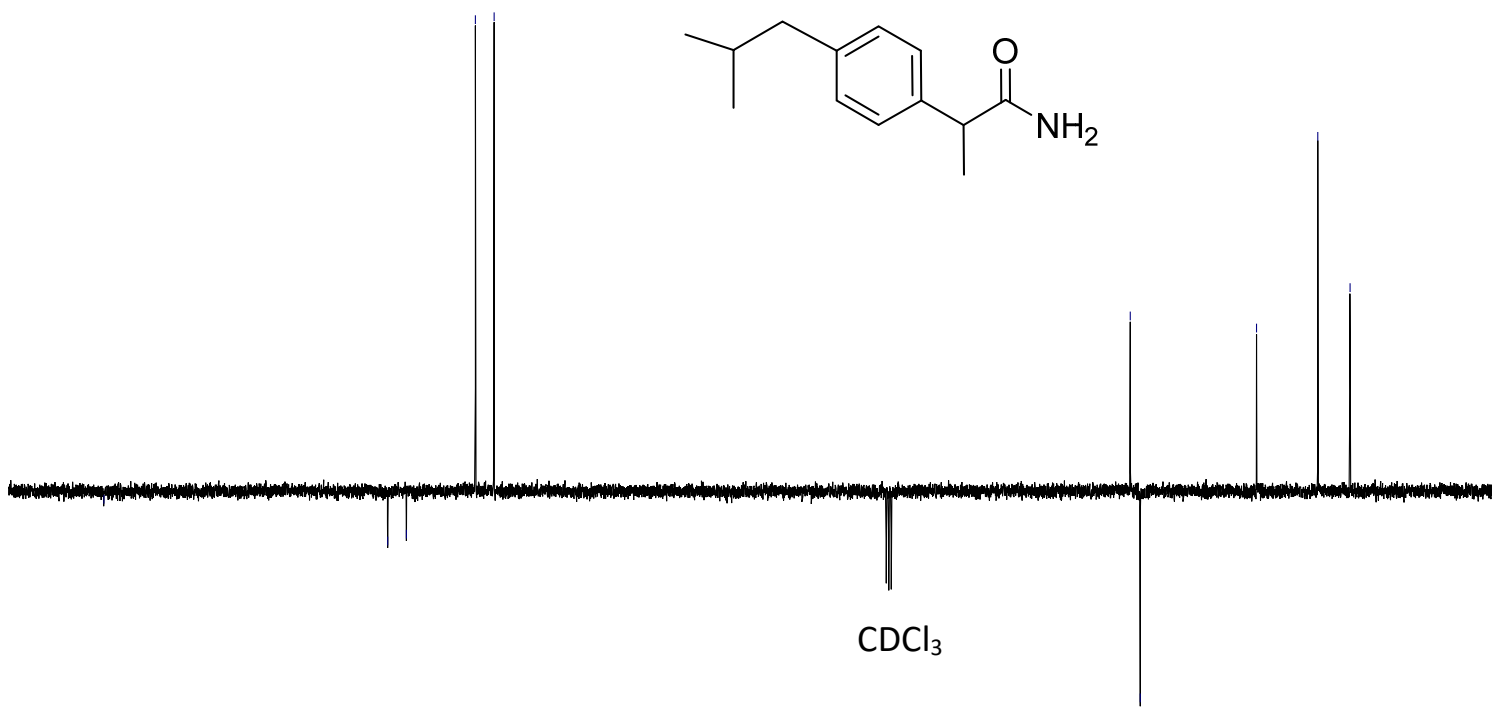

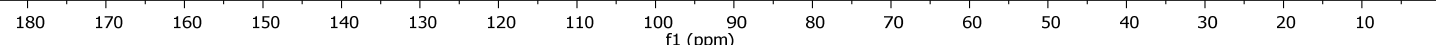

Figure S75. ${ }^{13} \mathrm{C}\left\{{ }^{1} \mathrm{H}\right\}$ APT NMR (100.63 $\left.\mathrm{MHz}, \mathrm{CDCl}_{3}, 298 \mathrm{~K}\right)$ spectrum of 2-(3isobutylphenyl)propanamide. 


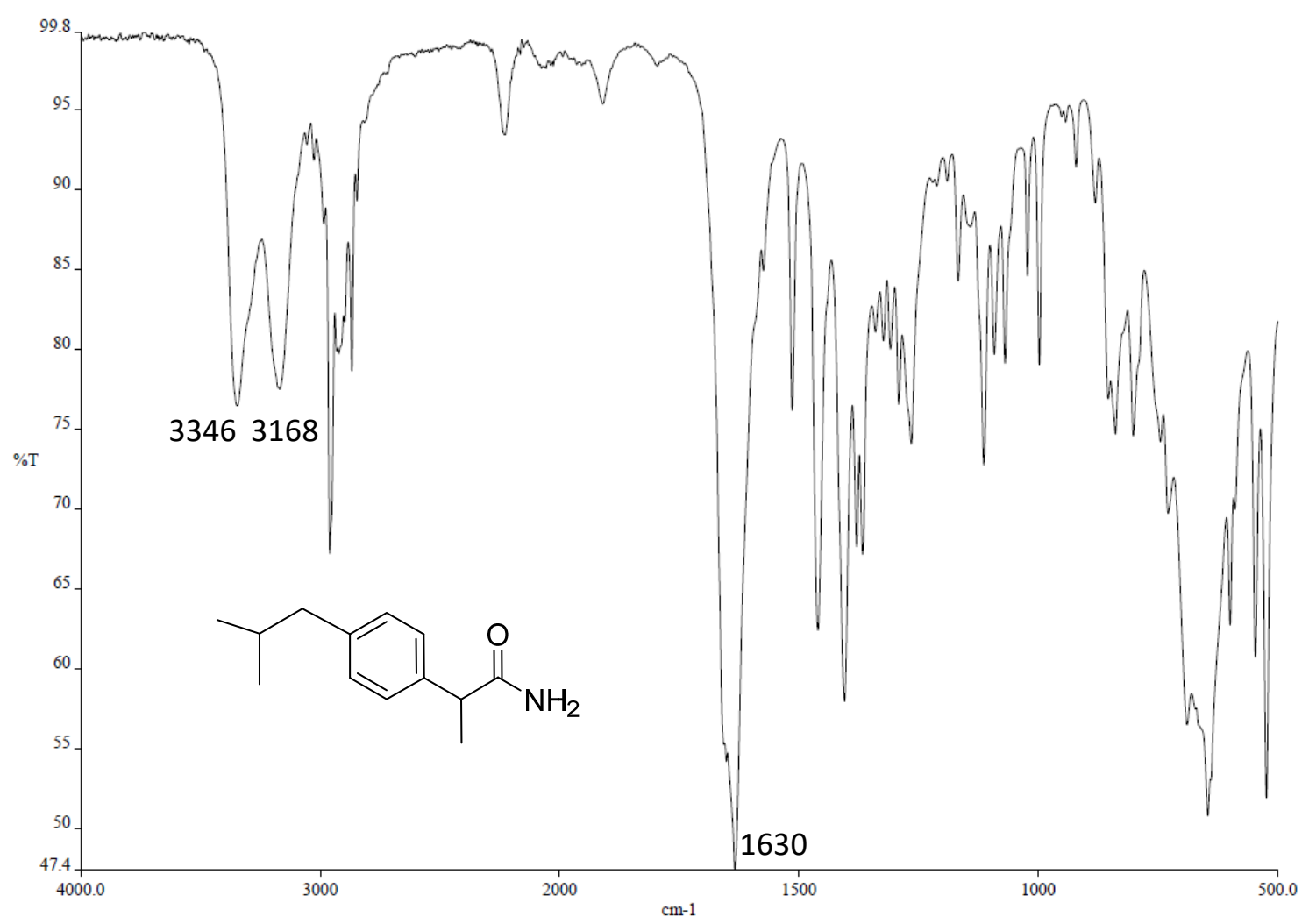

Figure S76. IR ATR spectrum of 2-(3-isobutylphenyl)propanamide.<smiles>CC(C(N)=O)c1cccc(C(=O)c2ccccc2)c1</smiles>

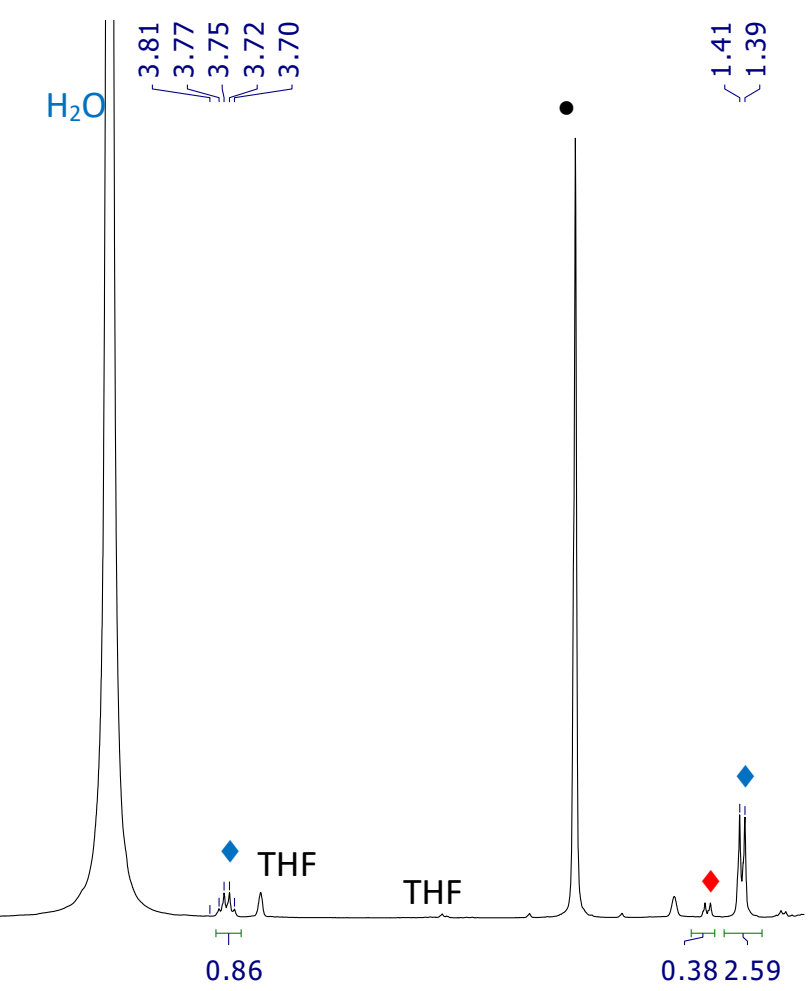

\begin{tabular}{lllllllllllllllllllllllllllllllllllllllllllllllllll}
\hline 7.8 & 7.6 & 7.4 & 7.2 & 7.0 & 6.8 & 6.6 & 6.4 & 6.2 & 6.0 & 5.8 & 5.6 & 5.4 & 5.2 & 5.0 & 4.8 & 4.6 & 4.4 & 4.2 & 4.0 & 3.8 & 3.6 & 3.4 & 3.2 & 3.0 & 2.8 & 2.6 & 2.4 & 2.2 & 2.0 & 1.8 & 1.6 & 1.4 & 1
\end{tabular}

Figure S77. ${ }^{1} \mathrm{H}$ NMR (300.13 MHz, THF- $\left.d_{8}, 298 \mathrm{~K}\right)$ spectrum of the reaction mixture of the hydration of 2-(3-benzoylphenyl)propionitrile ( $\bullet)$ formation of 2-(3benzoylphenyl)-propanamide $(\diamond) \cdot \bullet$ Mesitylene 
<smiles>CC(C(N)=O)c1cccc(C(=O)c2ccccc2)c1</smiles>

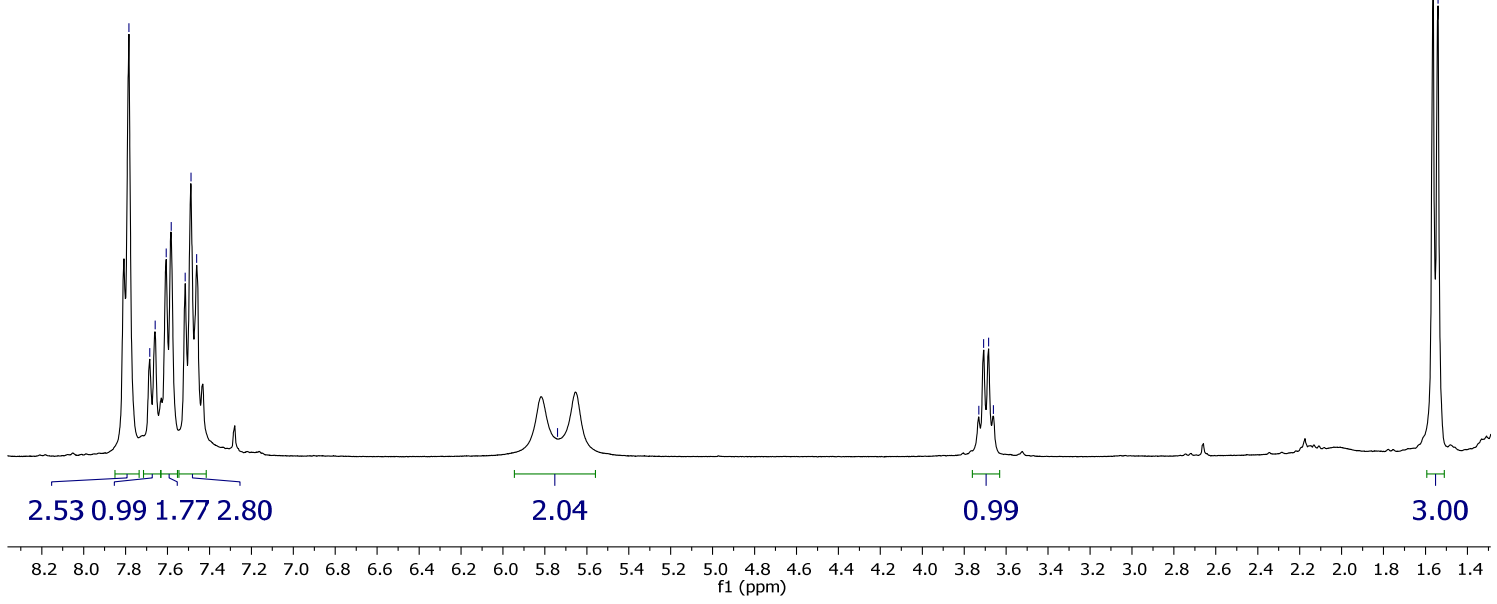

Figure S78. ${ }^{1} \mathrm{H}$ NMR (300.13 $\left.\mathrm{MHz}, \mathrm{CDCl}_{3}, 298 \mathrm{~K}\right)$ spectrum of 2-(3benzoylphenyl)propanamide.

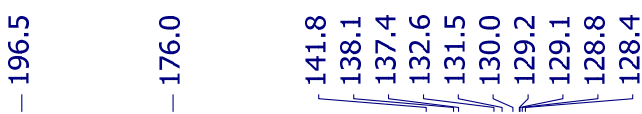
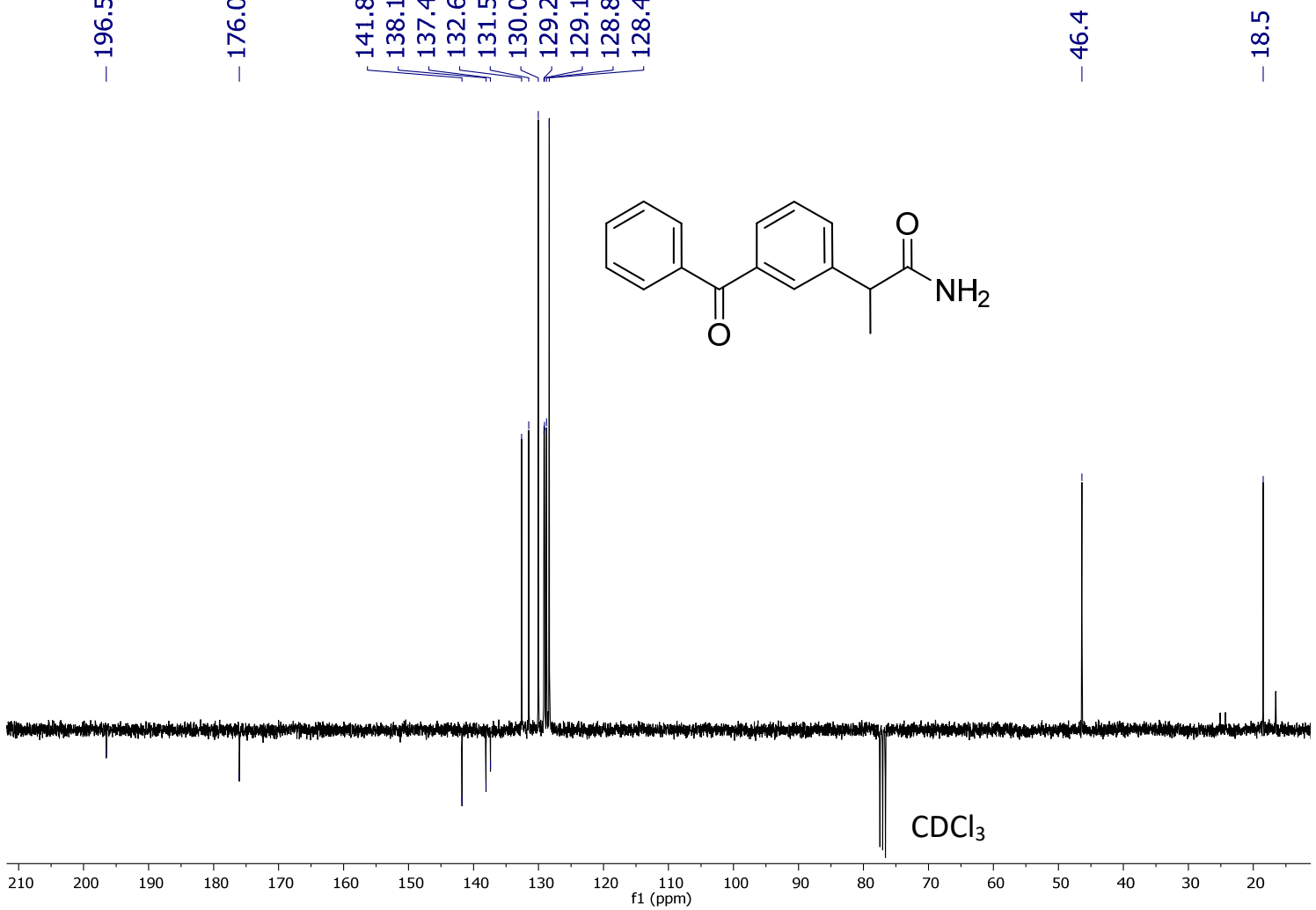

Figure S79. ${ }^{13} \mathrm{C}\left\{{ }^{1} \mathrm{H}\right\}$ APT NMR (75.48 $\left.\mathrm{MHz}, \mathrm{CDCl}_{3}, 298 \mathrm{~K}\right)$ spectrum of 2-(3benzoylphenyl)propanamide. 


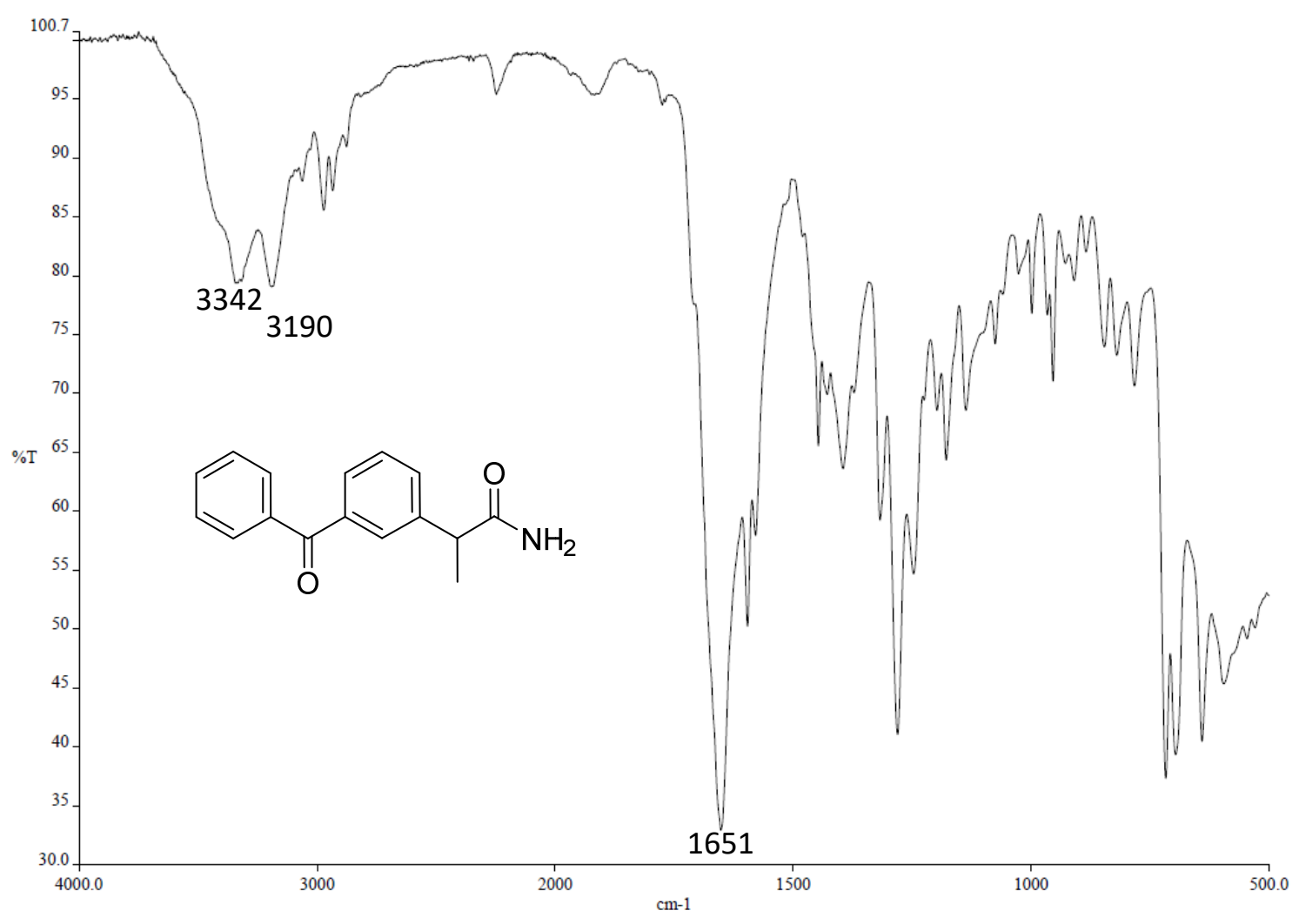

Figure S80. IR ATR spectrum of 2-(3-benzoylphenyl)propanamide.

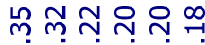

NNNNN

\begin{tabular}{ll}
$\stackrel{m}{*}$ & \multirow{\sigma}{+}{} \\
$\stackrel{+}{+}$ &
\end{tabular}

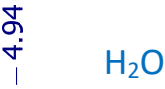

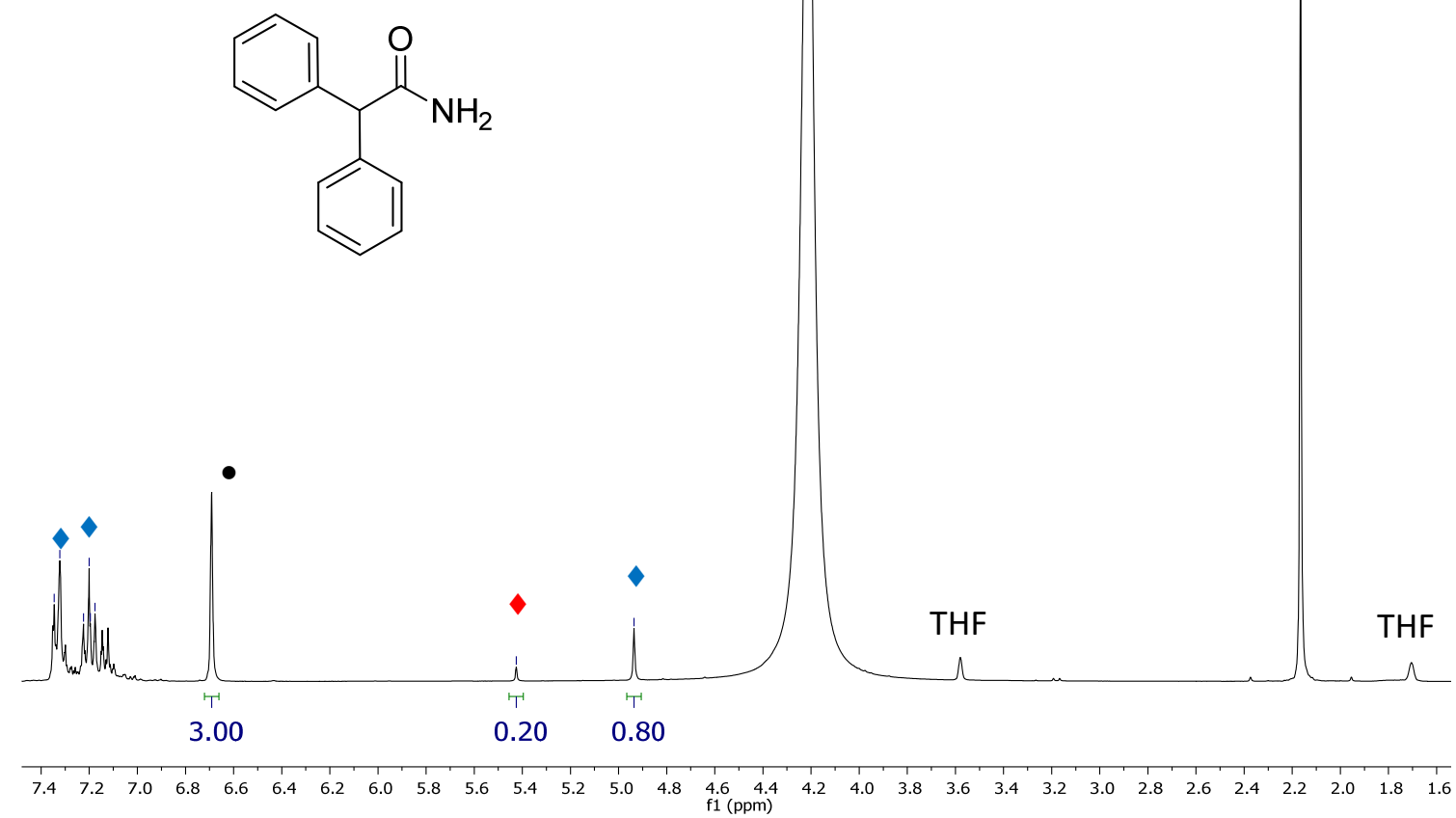

Figure S81. ${ }^{1} \mathrm{H}$ NMR $\left(300.13 \mathrm{MHz}, \mathrm{THF}-d_{8}, 298 \mathrm{~K}\right)$ spectrum of the reaction mixture of the hydration of 2,2-diphenylacetonitrile $(\diamond)$ : formation of 2,2-diphenylacetamide $(\diamond)$. $\bullet$ Mesitylene. 


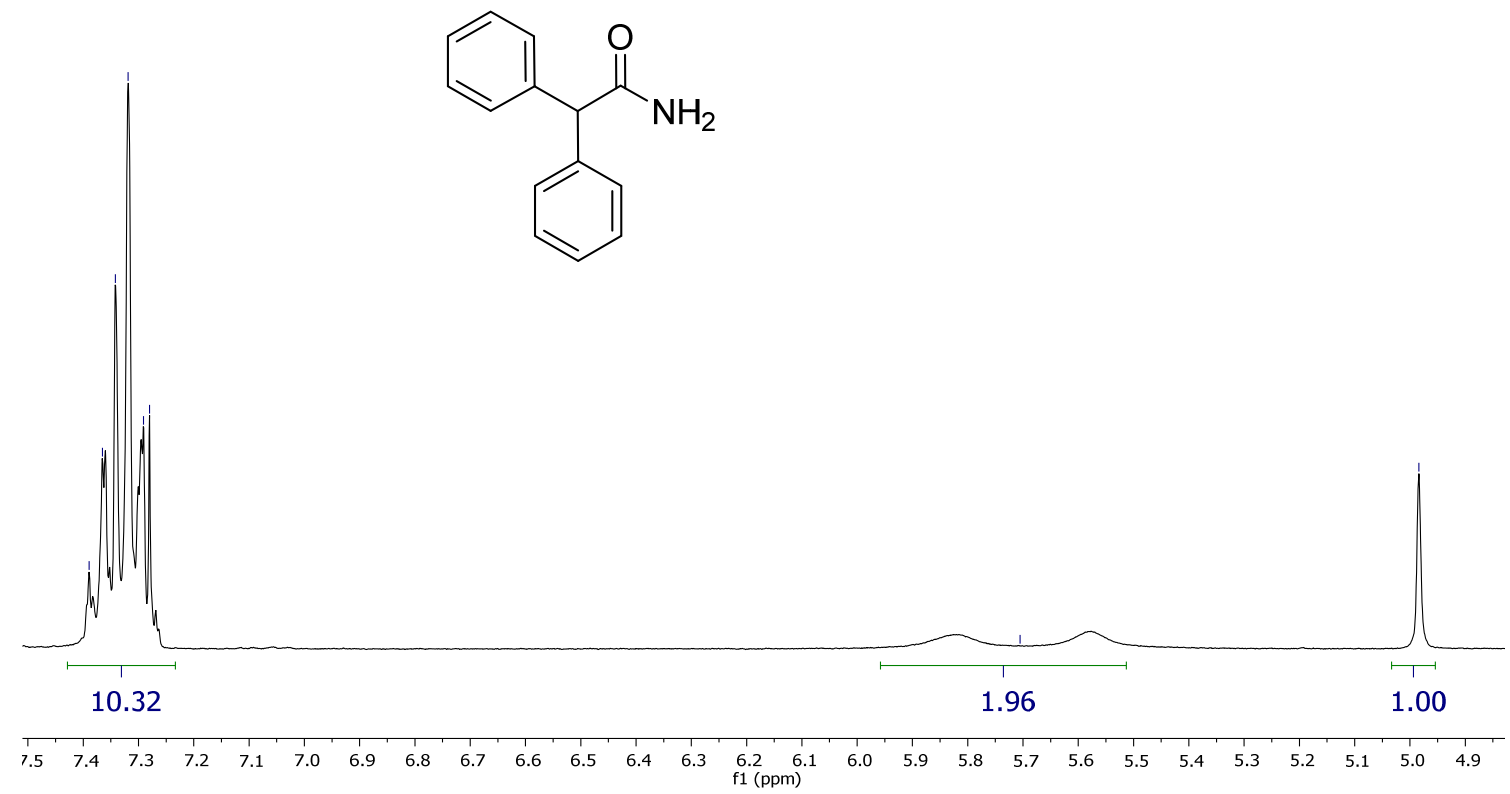

Figure S82. ${ }^{1} \mathrm{H}$ NMR (300.13 MHz, $\left.\mathrm{CDCl}_{3}, 298 \mathrm{~K}\right)$ spectrum of 2,2-diphenylacetamide.

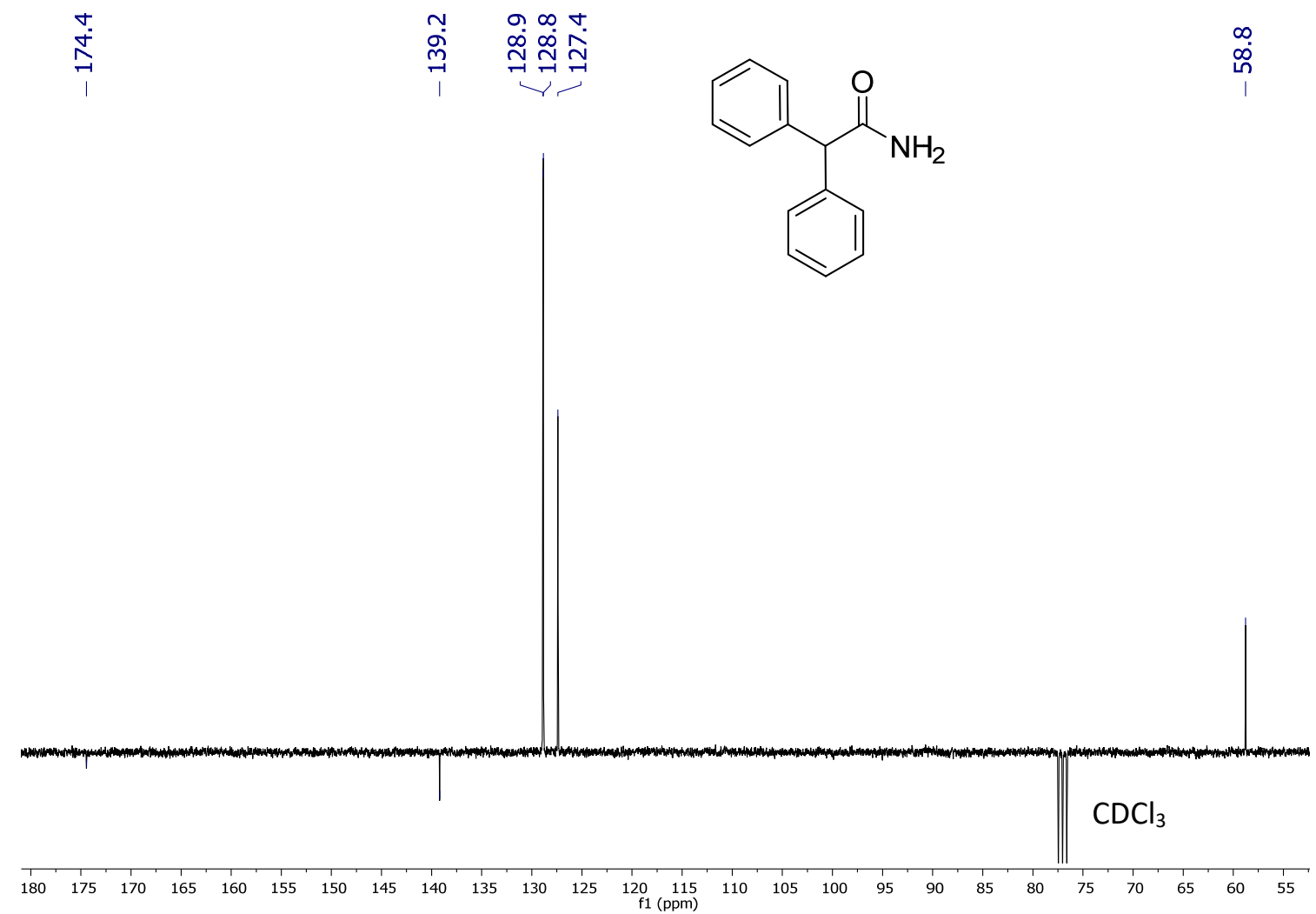

Figure S83. ${ }^{13} \mathrm{C}\left\{{ }^{1} \mathrm{H}\right\}$ APT NMR $\left(75.48 \mathrm{MHz}, \mathrm{CDCl}_{3}, 298 \mathrm{~K}\right)$ spectrum of 2,2diphenylacetamide. 


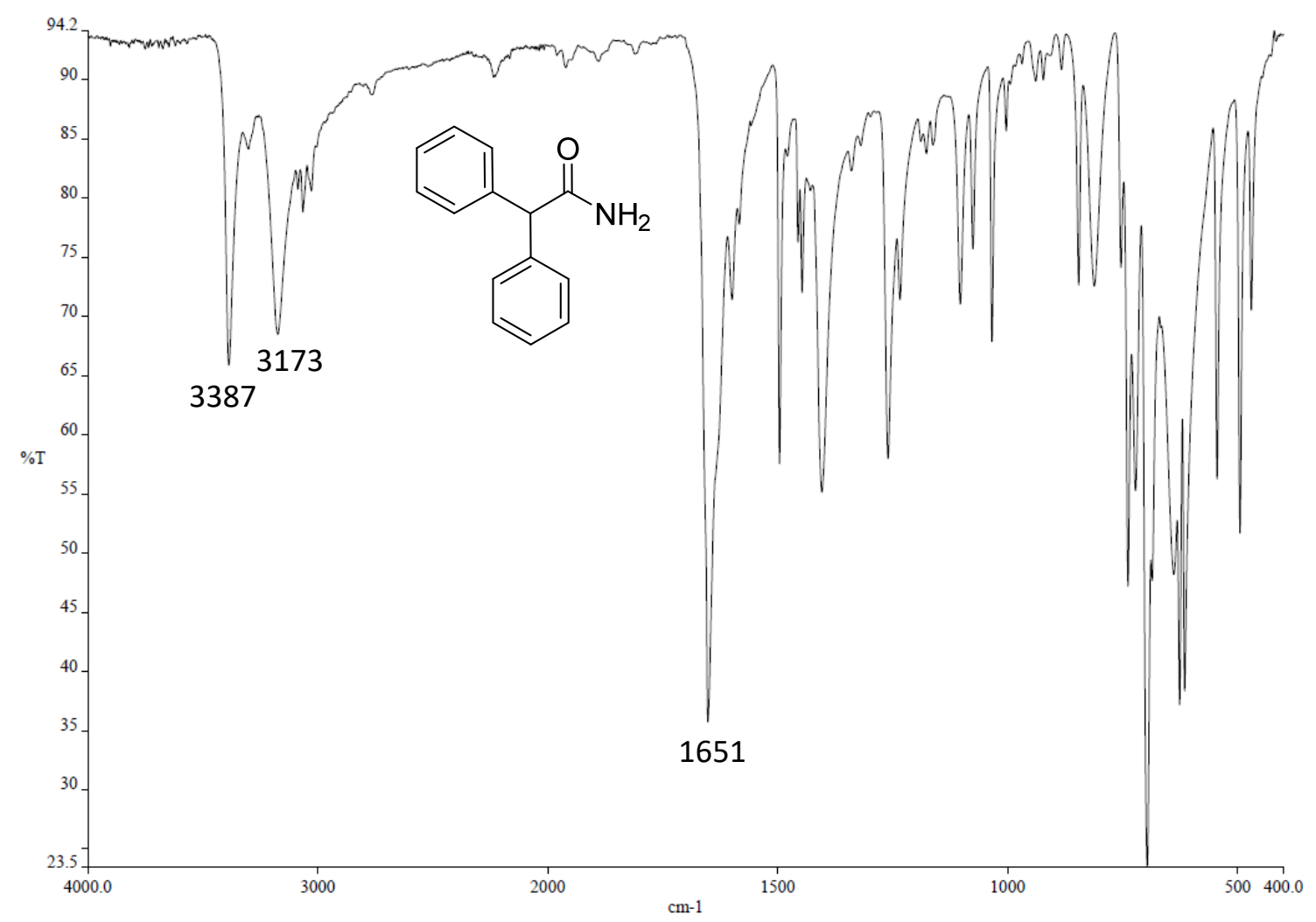

Figure S84. IR ATR spectrum of 2,2-diphenylacetamide.

${ }^{1} \mathrm{H},{ }^{31} \mathrm{P}\left\{{ }^{1} \mathbf{H}\right\},{ }^{13} \mathrm{C}\left\{{ }^{1} \mathrm{H}\right\}$ APT NMR spectra of complexes $2 \mathrm{a}$ and $2 \mathrm{~b}$.
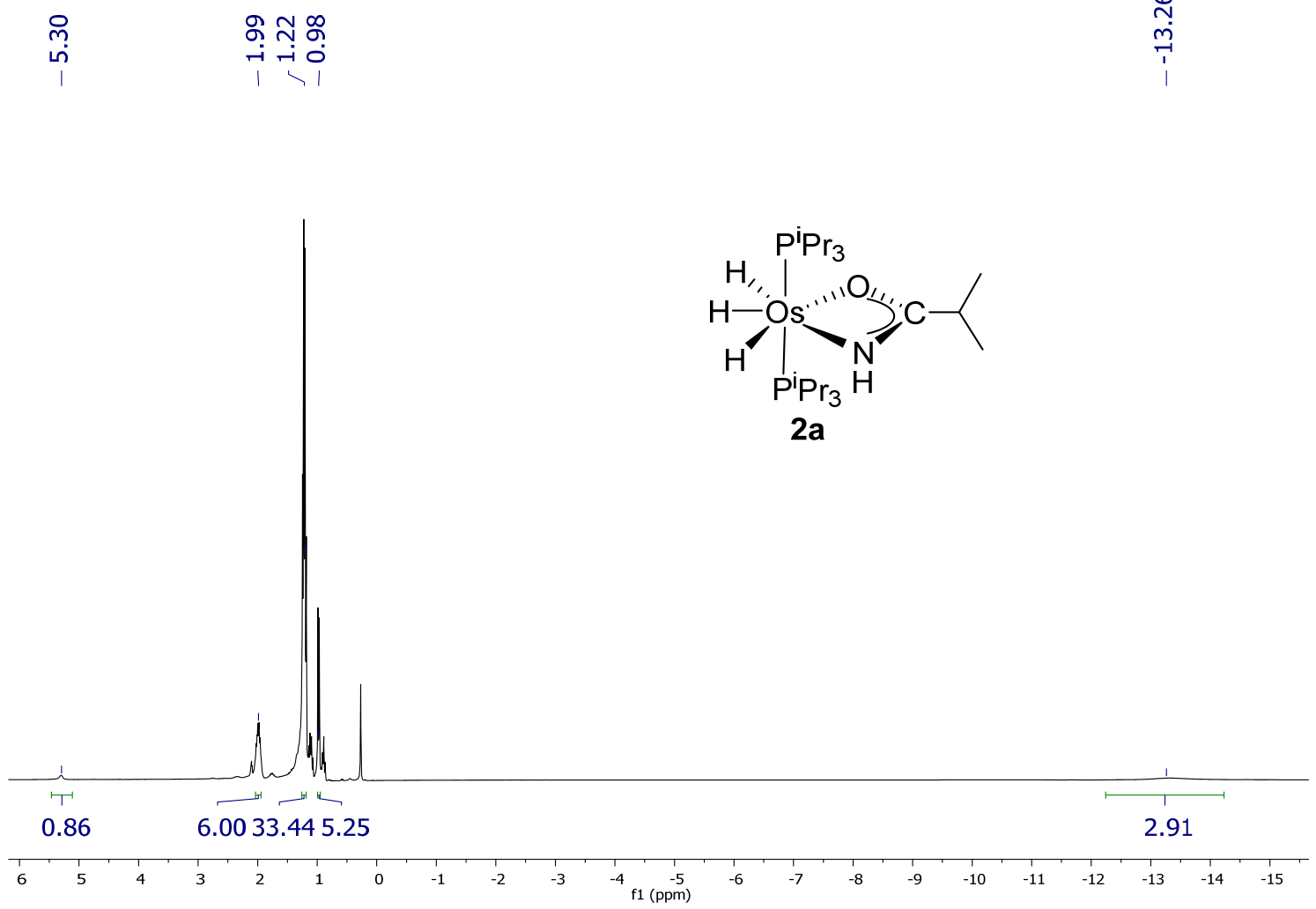

Figure S85. ${ }^{1} \mathrm{H}$ NMR $\left(300.13 \mathrm{MHz}, \mathrm{C}_{7} \mathrm{D}_{8}, 298 \mathrm{~K}\right)$ spectrum for complex $2 \mathbf{a}$. 
$313 \mathrm{~K}$

$298 \mathrm{~K}$

$273 \mathrm{~K}$

$253 \mathrm{~K}$

$233 \mathrm{~K}$

$213 \mathrm{~K}$

$193 \mathrm{~K}$

$183 \mathrm{~K}$

$\begin{array}{lllllllllllllllll}-9.8 & -10.2 & -10.6 & -11.0 & -11.4 & -11.8 & -12.2 & -12.6 & -13.0 & -13.4 & -13.8 & -14.2 & -14.6 & -15.0 & -15.4 & -15.8 & -16\end{array}$

Figure S86. High-field region of the ${ }^{1} \mathrm{H}$ NMR $\left(300.13 \mathrm{MHz}, \mathrm{C}_{7} \mathrm{D}_{8}\right)$ spectrum of complex 2a between $313 \mathrm{~K}$ and $183 \mathrm{~K}$.

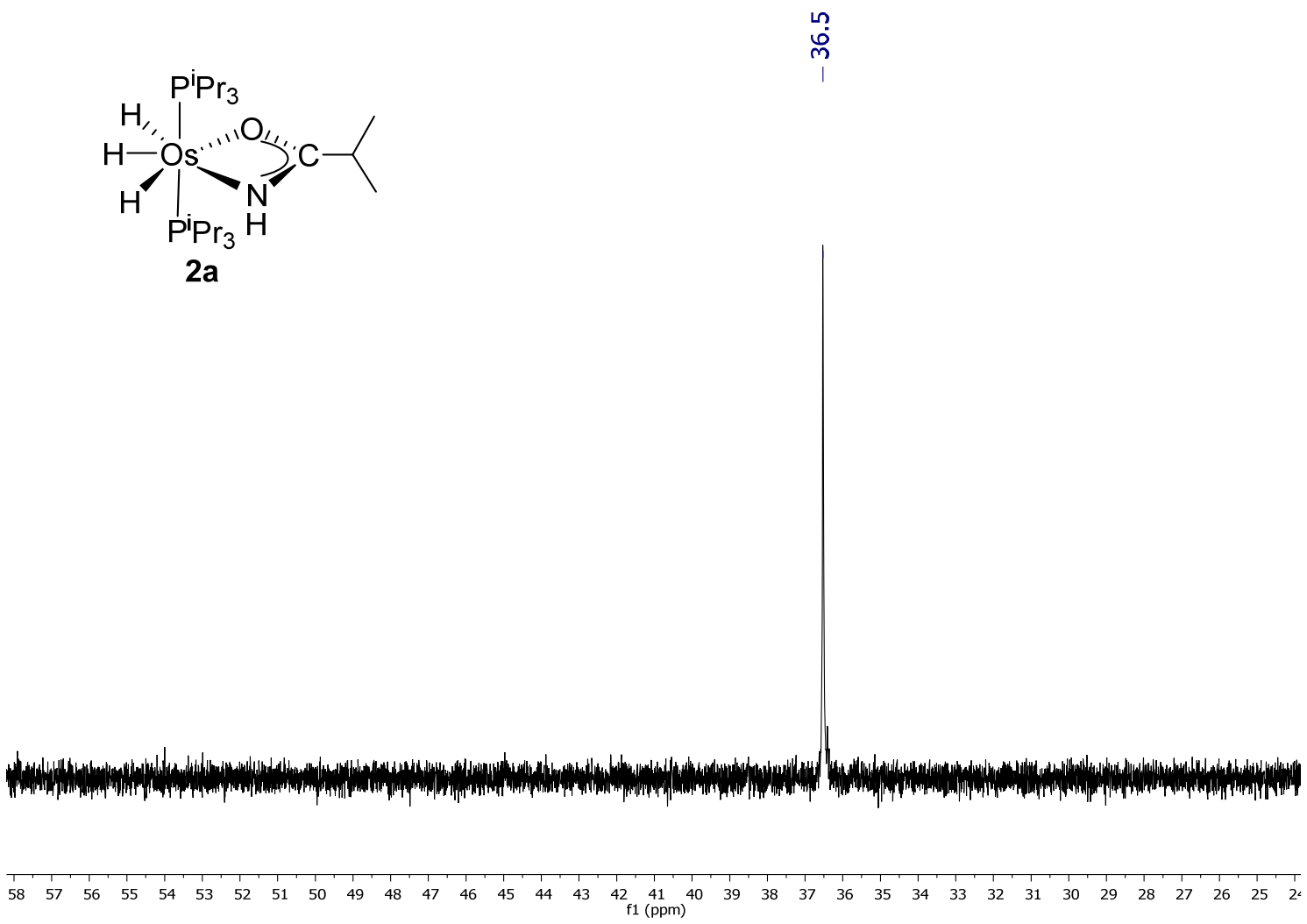

Figure S87. ${ }^{31} \mathrm{P}\left\{{ }^{1} \mathrm{H}\right\}$ NMR $\left(121.50 \mathrm{MHz}, \mathrm{C}_{7} \mathrm{D}_{8}, 298 \mathrm{~K}\right)$ spectrum for complex $2 \mathbf{a}$. 
$\underset{\substack{N \\-1 \\ 1}}{1}$

$\underset{\substack{1 \\ \stackrel{\infty}{-1}}}{\mathfrak{1}}$

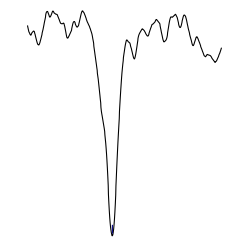

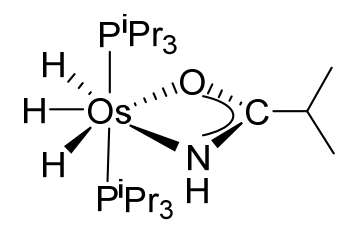

$2 \mathbf{a}$

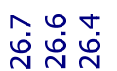

No
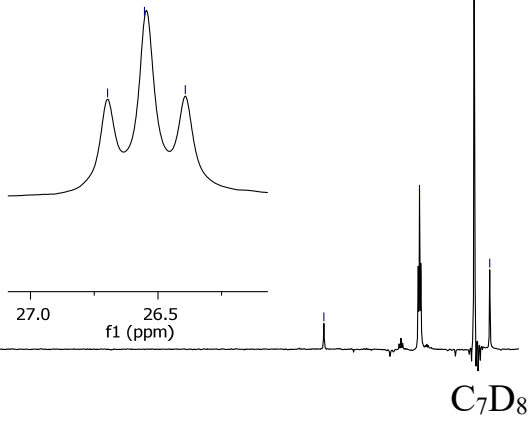

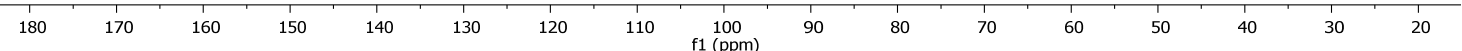

Figure S88. ${ }^{13} \mathrm{C}\left\{{ }^{1} \mathrm{H}\right\}$ APT NMR $\left(75.48 \mathrm{MHz}, \mathrm{CDCl}_{3}, 298 \mathrm{~K}\right)$ spectrum of complex $2 \mathbf{a}$.

में

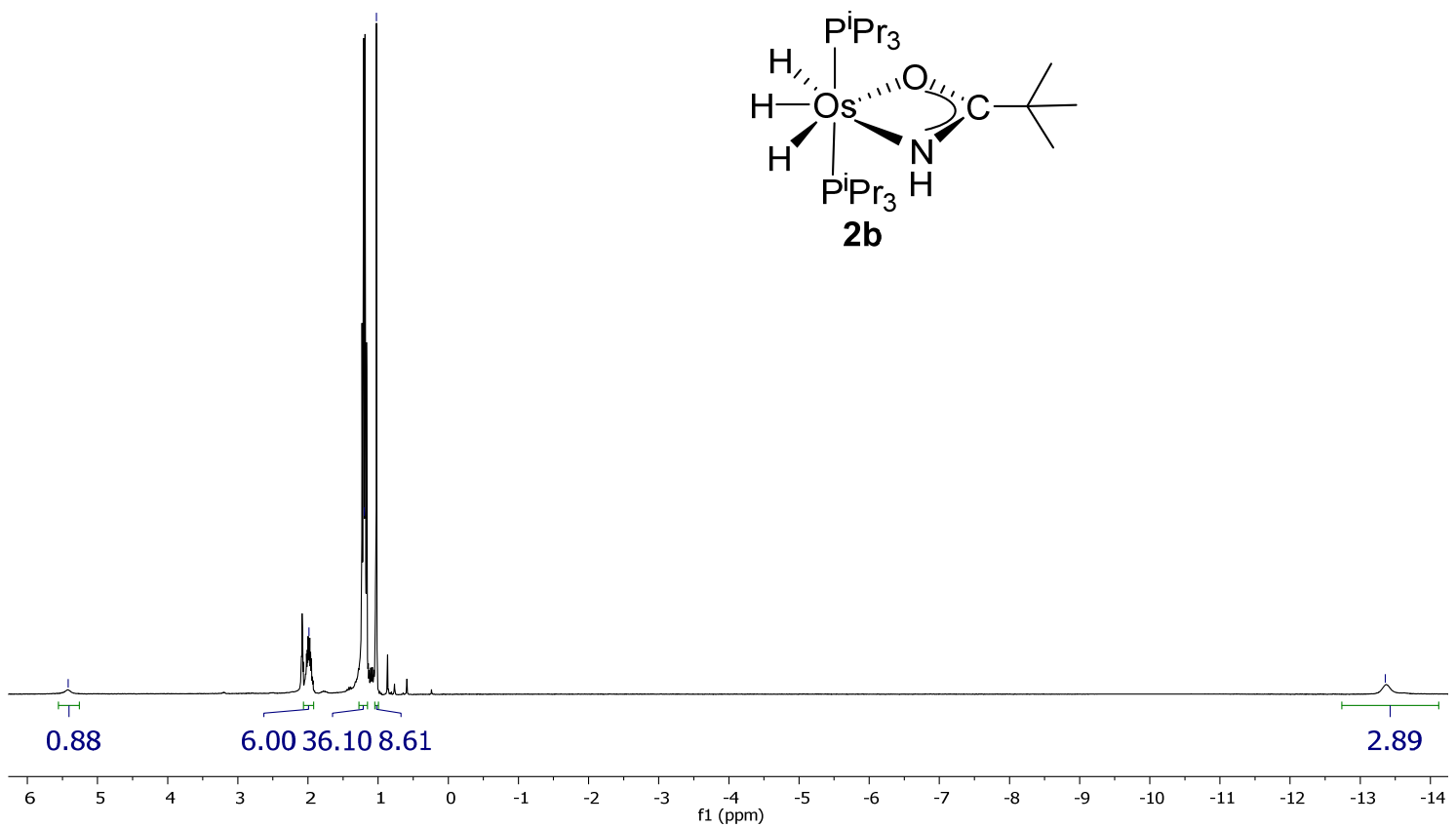

Figure S89. ${ }^{1} \mathrm{H}$ NMR $\left(300.13 \mathrm{MHz}, \mathrm{CDCl}_{3}, 298 \mathrm{~K}\right)$ spectrum for complex $\mathbf{2 b}$. 


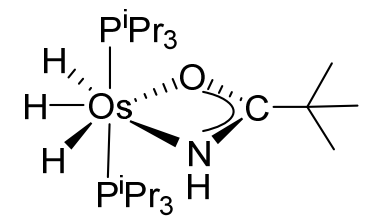

2b

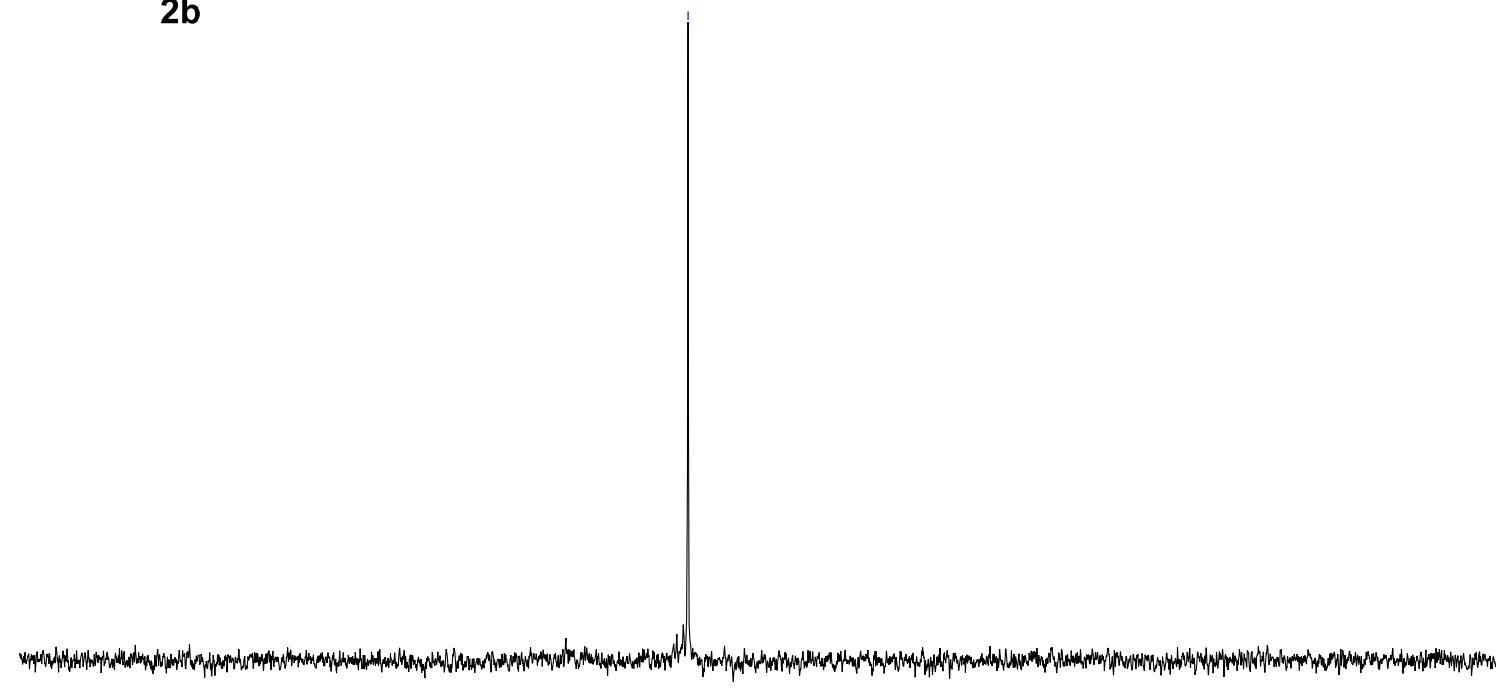

$\begin{array}{lllllllllllllllllllllllllllllllllllllll}150 & 140 & 130 & 120 & 110 & 100 & 90 & 80 & 70 & 60 & 50 & 40 & 30 & 20 & 10 & 0 & -10 & -20 & -30 & -40 & -50 & -60 & -70 & -80 & -90 & -10\end{array}$

Figure S90. ${ }^{31} \mathrm{P}\left\{{ }^{1} \mathrm{H}\right\}$ NMR (121.50 MHz, $\left.\mathrm{C}_{7} \mathrm{D} 8,298 \mathrm{~K}\right)$ spectrum for complex $\mathbf{2} \mathbf{b}$.

ก
N
-
|

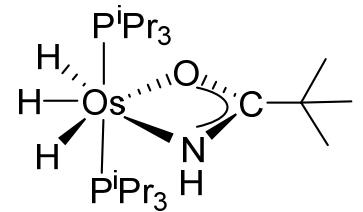

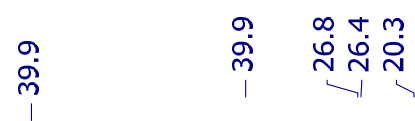

$2 b$
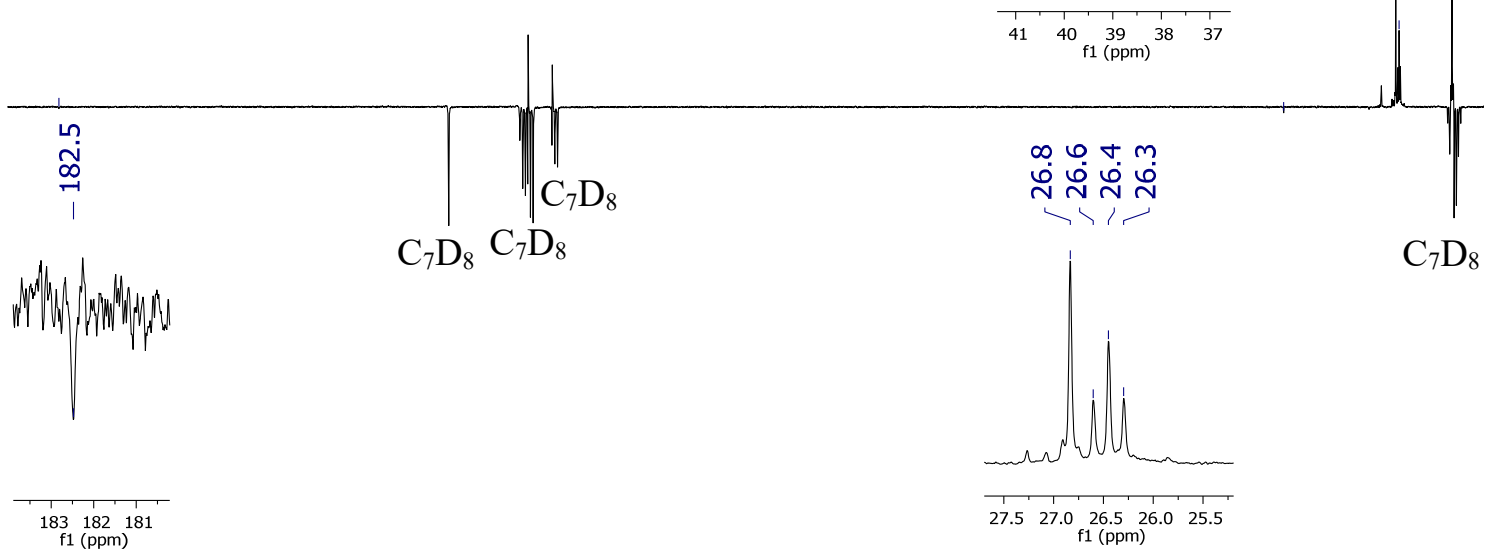

183182181
$\mathrm{f} 1(\mathrm{ppm})$

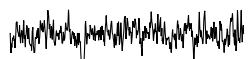

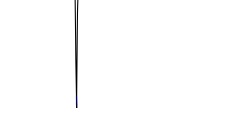




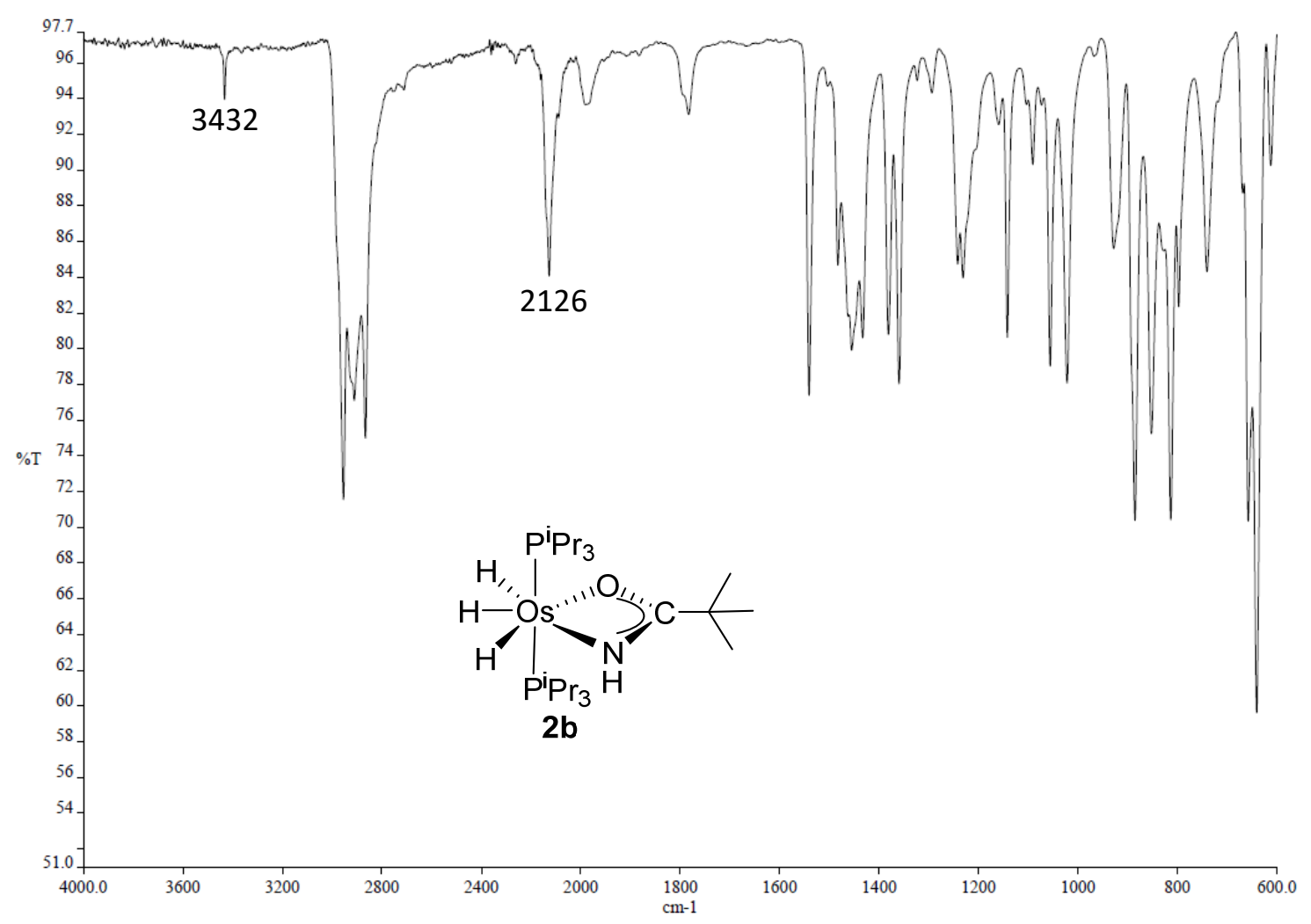

Figure S92. IR ATR spectrum of complex $2 \mathbf{b}$.

\section{Energy of computed structures}

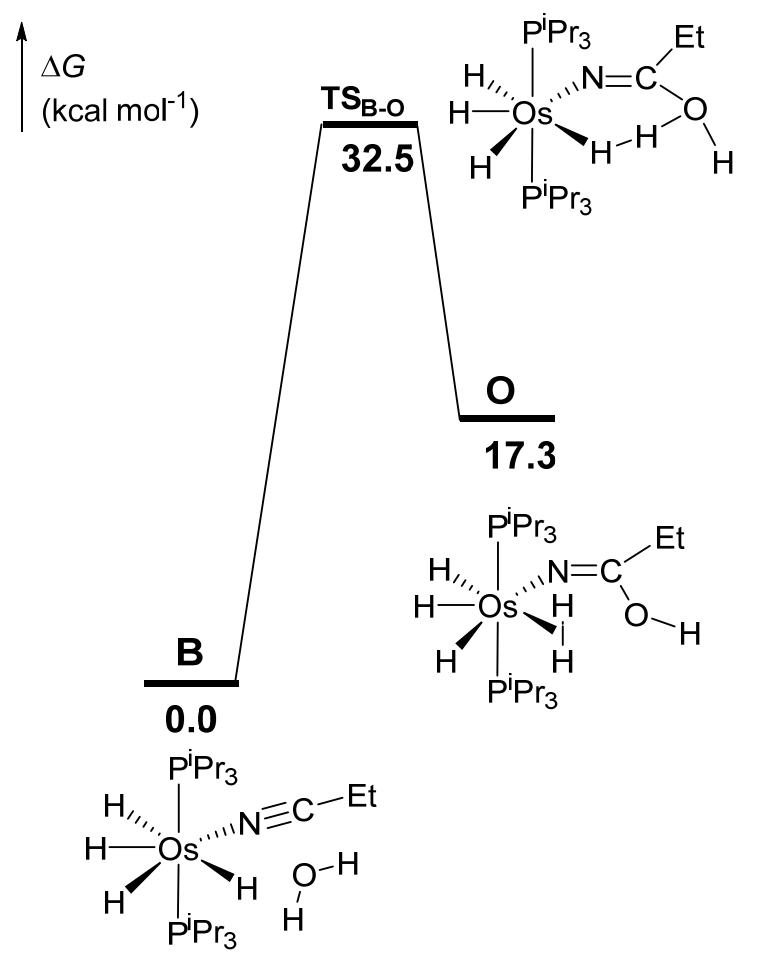

Figure S93. Computed energy profile for the nucleophilic attack of an external water molecule to the coordinated nitrile. 
$\mathrm{H}_{2} \mathrm{O}$

Zero-point correction=

0.021181 (Hartree/Particle)

Thermal correction to Energy=

0.024016

Thermal correction to Enthalpy=

0.024960

Thermal correction to Gibbs Free Energy=

0.003516

Sum of electronic and zero-point Energies=

$-76.404856$

Sum of electronic and thermal Energies=

$-76.402020$

Sum of electronic and thermal Enthalpies=

$-76.401076$

Sum of electronic and thermal Free Energies=

$-76.422520$

\section{Propionitrile}

Zero-point correction=

0.074232 (Hartree/Particle)

Thermal correction to Energy=

0.078935

Thermal correction to Enthalpy=

0.079879

Thermal correction to Gibbs Free Energy=

0.047479

Sum of electronic and zero-point Energies=

$-172.013166$

Sum of electronic and thermal Energies=

$-172.008463$

Sum of electronic and thermal Enthalpies=

$-172.007519$

Sum of electronic and thermal Free Energies=

$-172.039919$

\section{Propanamide}

Zero-point correction=

Thermal correction to Energy=

Thermal correction to Enthalpy=

Thermal correction to Gibbs Free Energy

Sum of electronic and zero-point Energies=

Sum of electronic and thermal Energies=

Sum of electronic and thermal Enthalpies=

Sum of electronic and thermal Free Energies=
0.102375 (Hartree/Particle)

0.108641

0.109585

0.072762

$-248.455963$

$-248.449697$

$-248.448753$

$-248.485576$

\section{Complex A}

Zero-point correction=

Thermal correction to Energy=

Thermal correction to Enthalpy=

Thermal correction to Gibbs Free Energy=

Sum of electronic and zero-point Energies=

Sum of electronic and thermal Energies=

Sum of electronic and thermal Enthalpies=

Sum of electronic and thermal Free Energies=
0.604451 (Hartree/Particle)

$$
0.637528
$$

0.638472

0.543242

$-1486.672132$

$-1486.639056$

$-1486.638112$

$-1486.733342$

\section{Complex B}

Zero-point correction=

Thermal correction to Energy=

Thermal correction to Enthalpy=

Thermal correction to Gibbs Free Energy=

Sum of electronic and zero-point Energies=

Sum of electronic and thermal Energies=
0.707984 (Hartree/Particle)

0.749424

0.750368

0.636751

$-1735.137734$

$-1735.096294$ 
Sum of electronic and thermal Enthalpies=

$-1735.095350$

Sum of electronic and thermal Free Energies=

$-1735.208966$

$\mathrm{TS}_{(\mathrm{B}-\mathrm{O})}$

Zero-point correction=

0.704794 (Hartree/Particle)

Thermal correction to Energy=

0.744469

Thermal correction to Enthalpy=

0.745413

Thermal correction to Gibbs Free Energy=

0.634687

Sum of electronic and zero-point Energies=

$-1735.087130$

Sum of electronic and thermal Energies=

$-1735.047455$

Sum of electronic and thermal Enthalpies=

$-1735.046511$

Sum of electronic and thermal Free Energies=

$-1735.157237$

\section{Complex 0}

Zero-point correction=

0.708807 (Hartree/Particle)

Thermal correction to Energy=

0.748478

Thermal correction to Enthalpy=

0.749422

Thermal correction to Gibbs Free Energy=

0.639407

Sum of electronic and zero-point Energies=

$-1735.112065$

Sum of electronic and thermal Energies=

$-1735.072394$

Sum of electronic and thermal Enthalpies=

Sum of electronic and thermal Free Energies=

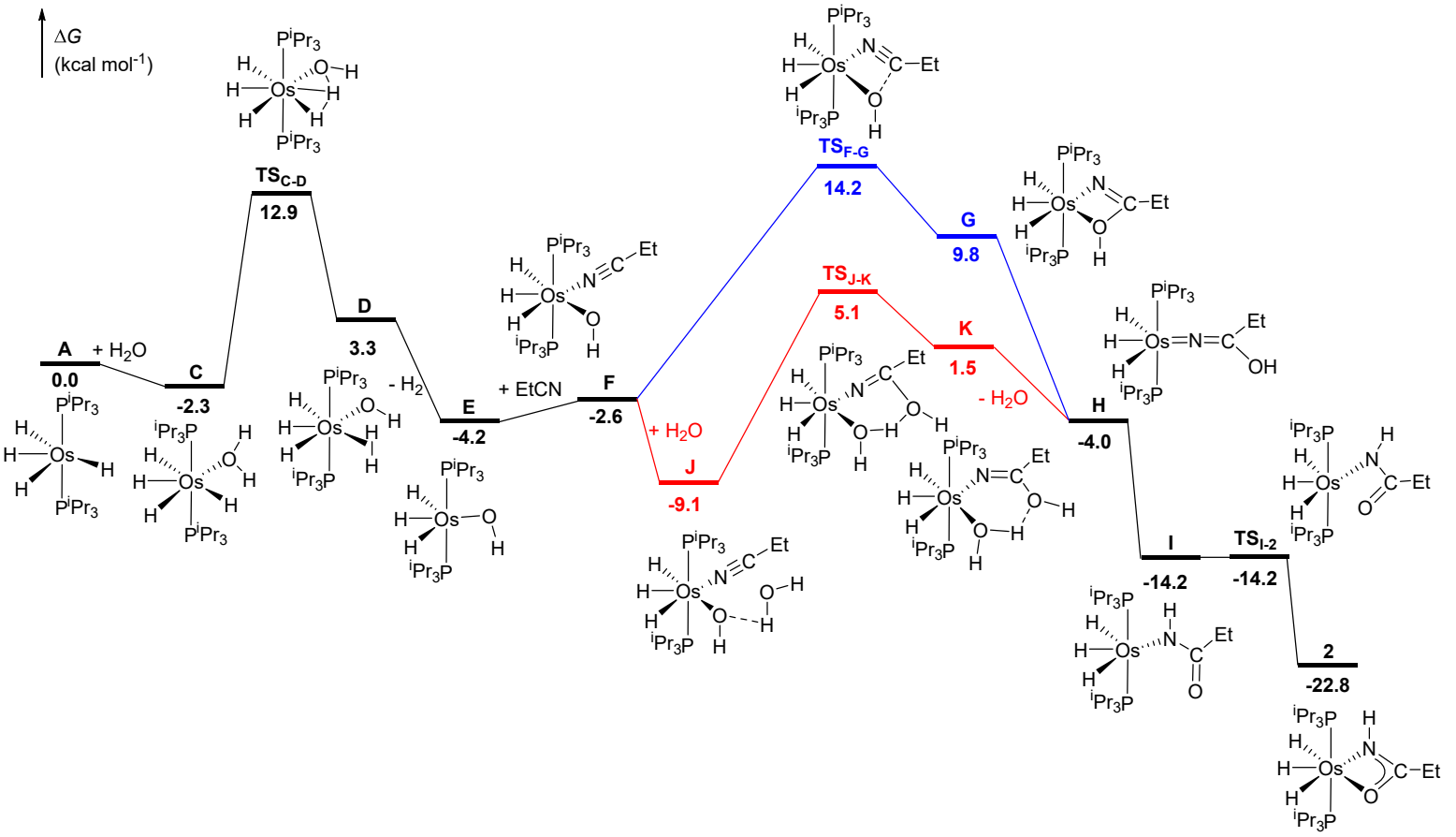

Figure S94. Computed energy profile for the formation of the $\kappa^{2}$-amidate (2) via intramolecular attack (blue lines) or intermolecular (red lines).

\section{Complex C}


Zero-point correction=

Thermal correction to Energy=

Thermal correction to Enthalpy=

Thermal correction to Gibbs Free Energy

Sum of electronic and zero-point Energies=

Sum of electronic and thermal Energies=

Sum of electronic and thermal Enthalpies=

Sum of electronic and thermal Free Energies=
0.632071 (Hartree/Particle)

0.667277

0.668221

0.568687

$-1563.096114$

$-1563.060908$

$-1563.059963$

$-1563.159497$

$\mathrm{TS}_{(\mathrm{C}-\mathrm{D})}$

Zero-point correction=

Thermal correction to Energy=

Thermal correction to Enthalpy=

Thermal correction to Gibbs Free Energy=

0.627153 (Hartree/Particle)

0.661729

0.662673

Sum of electronic and zero-point Energies=

0.564171

Sum of electronic and thermal Energies=

$-1563.072345$

$-1563.037769$

$-1563.036825$

Sum of electronic and thermal Enthalpies=

$-1563.135327$

\section{Complex D}

Zero-point correction=

Thermal correction to Energy=

Thermal correction to Enthalpy=

Thermal correction to Gibbs Free Energy=

Sum of electronic and zero-point Energies=

Sum of electronic and thermal Energies=

Sum of electronic and thermal Enthalpies=

Sum of electronic and thermal Free Energies=
0.630516 (Hartree/Particle)

0.665251

0.666195

0.567258

$-1563.087402$

$-1563.052667$

$-1563.051722$

$-1563.150660$

\section{Complex E}

Zero-point correction=

Thermal correction to Energy=

Thermal correction to Enthalpy=

Thermal correction to Gibbs Free Energy=

Sum of electronic and zero-point Energies=

Sum of electronic and thermal Energies=

Sum of electronic and thermal Enthalpies=

Sum of electronic and thermal Free Energies=
0.612561 (Hartree/Particle)

$$
0.647025
$$

0.647969

0.548415

$-1561.919112$

$-1561.884647$

$-1561.883703$

$-1561.983257$

\section{Complex F}

Zero-point correction=

Thermal correction to Energy=

Thermal correction to Enthalpy=

Thermal correction to Gibbs Free Energy=

Sum of electronic and zero-point Energies=

Sum of electronic and thermal Energies=

Sum of electronic and thermal Enthalpies=
0.689745 (Hartree/Particle)

0.729812

0.730756

\subsection{1}

$-1733.949833$

$-1733.909766$

$-1733.908822$ 
$\mathbf{T S}_{(\mathrm{F}-\mathrm{G})}$

Zero-point correction= 0.690416 (Hartree/Particle)

Thermal correction to Energy=

0.728914

Thermal correction to Enthalpy=

0.729859

Thermal correction to Gibbs Free Energy=

0.623741

Sum of electronic and zero-point Energies=

$-1733.927107$

Sum of electronic and thermal Energies=

$-1733.888609$

Sum of electronic and thermal Enthalpies=

$-1733.887664$

Sum of electronic and thermal Free Energies=

$-1733.993782$

\section{Complex G}

Zero-point correction=

Thermal correction to Energy=

Thermal correction to Enthalpy=

Thermal correction to Gibbs Free Energy=

Sum of electronic and zero-point Energies=

Sum of electronic and thermal Energies=

Sum of electronic and thermal Enthalpies=

Sum of electronic and thermal Free Energies=
0.691475 (Hartree/Particle)

0.730098

0.731042

0.624375

$-1733.933695$

$-1733.895072$

$-1733.894128$

$-1734.000795$

\section{Complex H}

Zero-point correction=

Thermal correction to Energy=

Thermal correction to Enthalpy=

Thermal correction to Gibbs Free Energy=

Sum of electronic and zero-point Energies=

Sum of electronic and thermal Energies=

Sum of electronic and thermal Enthalpies=

Sum of electronic and thermal Free Energies=
0.691001 (Hartree/Particle)

0.730301

0.731245

0.621564

$-1733.953422$

$-1733.914123$

$-1733.913179$

$-1734.022860$

\section{Complex I}

Zero-point correction=

Thermal correction to Energy=

Thermal correction to Enthalpy=

Thermal correction to Gibbs Free Energy=

Sum of electronic and zero-point Energies=

Sum of electronic and thermal Energies=

Sum of electronic and thermal Enthalpies=

Sum of electronic and thermal Free Energies=
0.691994 (Hartree/Particle)

0.731016

0.731960

0.623217

$-1733.970309$

$-1733.931288$

$-1733.930343$

$-1734.039086$

$\mathrm{TS}_{(1-2)}$

Zero-point correction=

Thermal correction to Energy=

Thermal correction to Enthalpy=

Thermal correction to Gibbs Free Energy=
0.690934 (Hartree/Particle)

0.729553

0.730497

0.622466 
Sum of electronic and zero-point Energies=

$-1733.971329$

Sum of electronic and thermal Energies=

$-1733.932710$

Sum of electronic and thermal Enthalpies=

$-1733.931766$

Sum of electronic and thermal Free Energies=

$-1734.039797$

\section{Complex 2}

Zero-point correction=

0.692421 (Hartree/Particle)

Thermal correction to Energy=

0.731170

Thermal correction to Enthalpy=

0.732114

Thermal correction to Gibbs Free Energy=

0.623732

Sum of electronic and zero-point Energies=

$-1733.984059$

Sum of electronic and thermal Energies=

$-1733.945310$

Sum of electronic and thermal Enthalpies=

$-1733.944366$

Sum of electronic and thermal Free Energies=

$-1734.052748$

\section{Complex J}
Zero-point correction=
0.715173 (Hartree/Particle)
Thermal correction to Energy=
0.757661
Thermal correction to Enthalpy=
0.758605
Thermal correction to Gibbs Free Energy=
0.642706
Sum of electronic and zero-point Energies=
$-1810.380974$
Sum of electronic and thermal Energies=
$-1810.338485$
Sum of electronic and thermal Enthalpies=
$-1810.337541$
Sum of electronic and thermal Free Energies=
$-1810.453440$

$\mathrm{TS}_{(\mathrm{J}-\mathrm{K})}$

Zero-point correction=

Thermal correction to Energy=

0.713038 (Hartree/Particle)

Thermal correction to Enthalpy=

0.753900

0.754844

Thermal correction to Gibbs Free Energy $=\quad 0.643004$

Sum of electronic and zero-point Energies $=\quad-1810.360754$

Sum of electronic and thermal Energies $=\quad-1810.319891$

Sum of electronic and thermal Enthalpies $=\quad-1810.318947$

Sum of electronic and thermal Free Energies $=\quad-1810.430787$

\section{Complex K}

Zero-point correction=

0.717594 (Hartree/Particle)

Thermal correction to Energy=

0.758831

Thermal correction to Enthalpy=

0.759775

Thermal correction to Gibbs Free Energy=

0.647294

Sum of electronic and zero-point Energies=

$-1810.366294$

Sum of electronic and thermal Energies=

$-1810.325057$

Sum of electronic and thermal Enthalpies=

$-1810.324113$

Sum of electronic and thermal Free Energies=

$-1810.436594$ 
$\uparrow \begin{aligned} & \Delta G \\ & \left(\mathrm{kcal} \mathrm{mol}^{-1}\right)\end{aligned}$

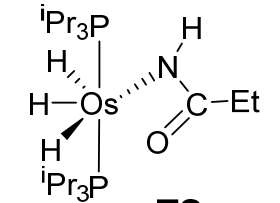

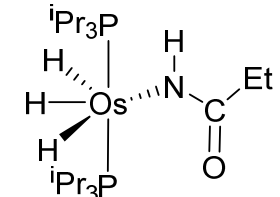

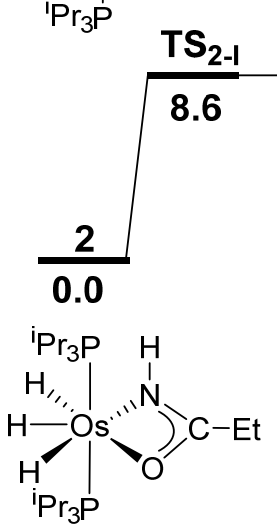
I
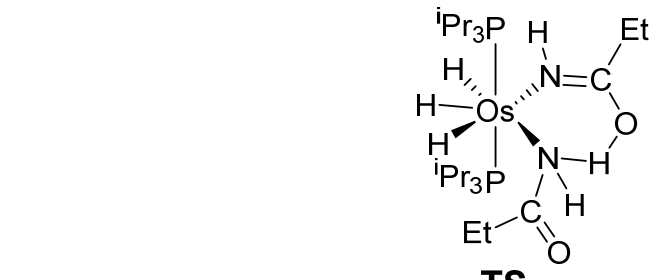

$\mathrm{TS}_{\mathrm{M}-\mathrm{N}}$

24.1

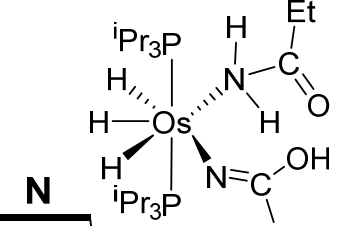

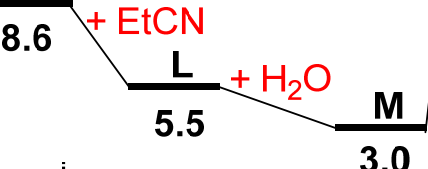

17.3

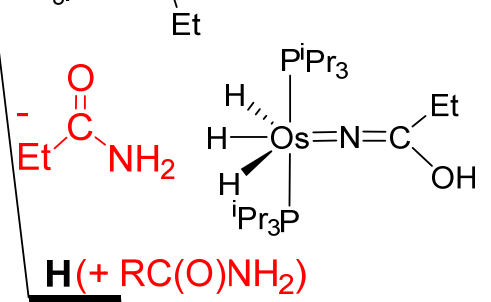

4.0

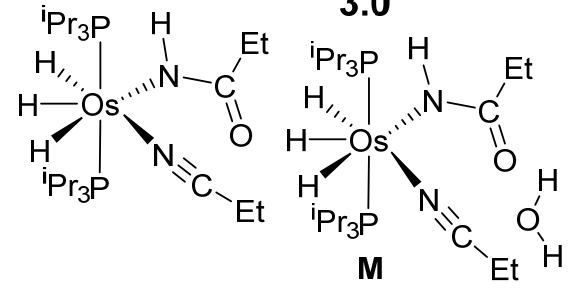

Figure S95. Computed energy profile for the catalytic cycle.

\section{Complex L}

Zero-point correction=

Thermal correction to Energy=

Thermal correction to Enthalpy=
0.770076 (Hartree/Particle)

$$
0.814295
$$$$
0.815240
$$

0.695408

$-1906.009235$

$-1905.965015$

$-1905.964071$

$-1906.083902$

\section{Complex M}

Zero-point correction=

Thermal correction to Energy=

Thermal correction to Enthalpy=

Thermal correction to Gibbs Free Energy=

Sum of electronic and zero-point Energies=

Sum of electronic and thermal Energies=

Sum of electronic and thermal Enthalpies=

Sum of electronic and thermal Free Energies=
0.795501 (Hartree/Particle)

$$
0.842365
$$

0.843309

0.718773

$-1982.433678$

$-1982.386815$

$-1982.385871$

$-1982.510407$

$\mathrm{TS}_{(\mathrm{M}-\mathrm{N})}$ 
Zero-point correction=

Thermal correction to Energy=

Thermal correction to Enthalpy=

Thermal correction to Gibbs Free Energy=

Sum of electronic and zero-point Energies=

Sum of electronic and thermal Energies=

Sum of electronic and thermal Enthalpies=

Sum of electronic and thermal Free Energies=
0.792413 (Hartree/Particle)

0.838008

0.838953

0.717283

$-1982.401694$

$-1982.356099$

$-1982.355155$

$-1982.476824$

\section{Complex $\mathbf{N}$}

Zero-point correction=

Thermal correction to Energy=

Thermal correction to Enthalpy=

Thermal correction to Gibbs Free Energy=

Sum of electronic and zero-point Energies=

Sum of electronic and thermal Energies=

Sum of electronic and thermal Enthalpies=

Sum of electronic and thermal Free Energies=
0.798300 (Hartree/Particle)

0.844046

0.844990

0.723580

$-1982.412995$

$-1982.367250$

$-1982.366306$

$-1982.487716$ 


\section{Comparative tables of metal-catalyzed nitrile hydration}

Table S1. Transition metal catalyzed hydration of nitriles showing the number of aryl, alkyl and vinyl nitriles used for each catalyst

\begin{tabular}{|c|c|c|c|c|}
\hline Catalyst & $\begin{array}{c}\text { Aryl } \\
\text { Nitriles }\end{array}$ & $\begin{array}{c}\text { Alkyl } \\
\text { Nitriles }\end{array}$ & $\begin{array}{c}\text { Vinyl } \\
\text { Nitriles }\end{array}$ & ref $^{\mathbf{a}}$ \\
\hline$(\mathrm{MeCp})_{2} \mathrm{Mo}(\mathrm{OH})\left(\mathrm{H}_{2} \mathrm{O}\right)^{+}$ & 2 & 7 & 1 & $6 \mathrm{~b}$ \\
\hline$\left[\mathrm{PtCl}\left(\mathrm{PR}_{2} \mathrm{OH}\right)-\left\{\left(\mathrm{PR}_{2} \mathrm{O}\right)_{2} \mathrm{H}\right\}\right]$ and $\mathrm{Cp}_{2} \mathrm{Mo}(\mathrm{OH})\left(\mathrm{OH}_{2}\right)$ & 0 & 13 & 0 & $11 \mathrm{~d}$ \\
\hline $\mathrm{Na}_{2} \mathrm{MoO}_{4} \cdot 2 \mathrm{H}_{2} \mathrm{O}$ & 9 & 3 & 0 & 10 \\
\hline$\left(\eta^{5}-\mathrm{C}_{9} \mathrm{H}_{7}\right) \mathrm{Ru}(\mathrm{dppm}) \mathrm{H}$ & 3 & 1 & 0 & $12 \mathrm{a}$ \\
\hline cis-Ru(acac $)_{2}\left(\mathrm{PPh}_{2} \mathrm{py}\right)_{2}$ & 5 & 5 & 3 & $8 \mathrm{a}$ \\
\hline $\begin{array}{l}\mathrm{L}_{2} \mathrm{Ru}(\mathrm{acac})_{2}(\mathrm{~L}=6 \text {-diphenylphosphino-N-pivaloyl-2- } \\
\text { aminopyridine or 3-diphenylphosphinoisoquinolone) }\end{array}$ & 1 & 0 & 0 & $8 \mathrm{~b}$ \\
\hline $\begin{array}{c}{\left[\mathrm{RuCl}_{2}\left(\eta^{6}-\mathrm{C}_{6} \mathrm{Me}_{6}\right)(\mathrm{PTA}-\mathrm{Bn})\right](\mathrm{PTA}-\mathrm{Bn}=1 \text {-benzyl-3,5-diaza-1- }} \\
\text { azonia-7-phosphaadamantane chloride) }\end{array}$ & 29 & 11 & 5 & $12 b$ \\
\hline$\left\{\left[\left(\mathrm{PC} y_{3}\right)(\mathrm{CO}) \mathrm{RuH}\right]_{4}\left(\mu^{4}-\mathrm{O}\right)\left(\mu^{3}-\mathrm{OH}\right)\left(\mu^{2}-\mathrm{OH}\right)\right\}$ & 3 & 7 & 3 & $13 \mathrm{c}$ \\
\hline $\mathrm{TpRu}\left(\mathrm{PPh}_{3}\right)\left(\mathrm{H}_{2} \mathrm{O}\right)\left(\mathrm{NHC}(\mathrm{O}) \mathrm{CH}_{3}\right)$ & 3 & 7 & 0 & $9 \mathrm{a}$ \\
\hline$\left[\mathrm{Ru}\left(\mathrm{H}_{2} \mathrm{O}\right)(\mathrm{NCMe})_{4}\left(\mathrm{P}^{i} \mathrm{Pr}_{3}\right)\right]\left(\mathrm{BF}_{4}\right)_{2}$ & 0 & 1 & 0 & $12 \mathrm{c}$ \\
\hline $\mathrm{RuCl}_{2}-\left\{\kappa^{1}(\mathrm{P})-3-\mathrm{Ph}_{2} \mathrm{PC}_{6} \mathrm{H}_{4} \mathrm{CH}_{2} \mathrm{NH}^{t} \mathrm{Bu}\right\}\left(\eta^{6}-1,3,5-\mathrm{C}_{6} \mathrm{H}_{3} \mathrm{Me}_{3}\right)$ & 10 & 3 & 1 & $12 \mathrm{~d}$ \\
\hline $\begin{array}{c}\mathrm{RuCl}_{2}\left(\eta^{3}: \eta^{3}-\mathrm{C}_{10} \mathrm{H}_{16}\right)(\mathrm{THPA})(\mathrm{THPA}=2,4,10 \text {-trimethyl- } \\
1,2,4,5,7,10 \text {-hexaaza-3-phosphatricyclo[3.3.1.13,7]decane) }\end{array}$ & 16 & 5 & 1 & $12 \mathrm{e}$ \\
\hline $\mathrm{RuCl}_{2}\left(\eta^{6}\right.$-arene $)\left(\mathrm{PR}_{3}\right)$ & 4 & 4 & 1 & $12 \mathrm{f}$ \\
\hline$\left[\mathrm{RuCl}_{2}(\mathrm{~L})(\mathrm{dmso}-\mathrm{S})_{3}\right](\mathrm{L}=$ pirazols $)$ & 1 & 0 & 1 & $12 \mathrm{~g}$ \\
\hline $\mathrm{RuCl}_{2}\left(\eta^{6}-\mathrm{C}_{6} \mathrm{Me}_{6}\right)-\left\{\mathrm{P}\left(\mathrm{NMe}_{2}\right)_{3}\right\}$ & 21 & 11 & 2 & $6 \mathrm{~d}$ \\
\hline $\mathrm{Ru}(\text { methallyl })_{2}(\mathrm{cod})$ & 8 & 3 & 2 & $12 \mathrm{~h}$ \\
\hline $\mathrm{RuCl}_{2}(\mathrm{PTA})_{4}$ & 11 & 2 & 1 & $12 \mathrm{i}$ \\
\hline $\mathrm{RuCl}_{2}\left(\eta^{6}\right.$-p-cymene $)\left\{\kappa^{1}-(\mathrm{P})-\mathrm{PPh}_{2} \mathrm{py}\right\}$ & 1 & 0 & 0 & $12 \mathrm{j}$ \\
\hline $\mathrm{Ru}\left(\eta^{6}-p\right.$-cymene $) \mathrm{Cl}_{2}\left(\mathrm{P}\left(\mathrm{NMe}_{2}\right)_{3}\right)$ & 0 & 3 & 0 & $12 \mathrm{k}$ \\
\hline $\mathrm{Ru}(\mathrm{II})$ catalysts inspired by the metalloenzyme & 1 & 0 & 0 & 121 \\
\hline $\mathrm{RuCl}_{2}\left(\eta^{6}\right.$-p-cymene $)+\mathrm{N}$-protonated thiazolyl-phosphine & 19 & 7 & 3 & $12 \mathrm{~m}$ \\
\hline $\mathrm{Ru}\left(\eta^{6}\right.$-arene $) \mathrm{Cl}_{2}\left(\mathrm{P}\left(\mathrm{NMe}_{2}\right)_{3}\right)$ & 0 & 5 & 0 & $12 \mathrm{n}$ \\
\hline $\mathrm{Ru}\left(\eta^{6}\right.$-p-cymene $) \mathrm{Cl}_{2}\left(\mathrm{P}(\mathrm{OH}) \mathrm{Me}_{2}\right)$ & 1 & 6 & 2 & 120 \\
\hline$\left[\left(\eta^{6}-\mathrm{C}_{6} \mathrm{H}_{5} \mathrm{CH}_{3}\right) \mathrm{RuCl}\left(\kappa^{2}-(P, N) \mathrm{PTA}-\mathrm{CPh}_{2} \mathrm{NHPh}\right)\right] \mathrm{Cl}$ & 10 & 2 & 1 & $12 p$ \\
\hline $\mathrm{RuCl}_{2}(\mathrm{pypz}-\mathrm{H})(\mathrm{dmso})_{2}$ and $\mathrm{RuCl}_{2}(\mathrm{pz}-\mathrm{H})(\mathrm{dmso})_{3}$ & 5 & 3 & 1 & $12 \mathrm{q}$ \\
\hline$\left[\operatorname{RuOTf}\left\{\eta^{6}: k^{1}(\mathrm{P})-\mathrm{PPh}_{2}\right.\right.$-binaphthyl $\left.\}\left\{\mathrm{PPh}_{2}(\mathrm{OH})\right\}\right][\mathrm{OTf}]$ & 21 & 7 & 1 & $12 \mathrm{r}$ \\
\hline $\mathrm{RuCl}_{2}(\mathrm{dmso})_{4}$ and $\left[\left(\eta^{6}-p \text {-cymene }\right) \mathrm{RuCl}_{2}\right]_{2}$ & 8 & 8 & 0 & $12 \mathrm{~s}$ \\
\hline$\left[\left(\eta^{6}\right.\right.$-toluene $\left.) \mathrm{RuCl}_{2}\left(\mathrm{PTA}^{\mathrm{P}} \mathrm{P}^{\mathrm{i}} \mathrm{Pr}_{2}\right)\right]$ & 5 & 1 & 1 & $12 \mathrm{t}$ \\
\hline $\mathrm{RuCl}_{2}(\mathrm{~L})(\mathrm{dmso}-\mathrm{S})_{3}$ & 1 & 0 & 1 & $6 \mathrm{~h}$ \\
\hline$\left[\mathrm{RuCl}_{2}\left(\eta^{6}\right.\right.$-arene $\left.)\left\{\mathrm{P}(\mathrm{OR})_{2} \mathrm{OH}\right\}\right]$ & 1 & 1 & 0 & $12 u$ \\
\hline$\left[\mathrm{RuCl}_{2}\left(\eta^{6}\right.\right.$-p - -cymene $\left.)\left\{\mathrm{P}\left(4-\mathrm{C}_{6} \mathrm{H}_{4} \mathrm{~F}\right)_{2} \mathrm{Cl}\right\}\right]$ & 16 & 17 & 1 & $12 \mathrm{v}$ \\
\hline$\left[\mathrm{RuCl}_{2}\left(\eta^{3}: \eta^{3}-\mathrm{C}_{10} \mathrm{H}_{16}\right)\left(\mathrm{PMe}_{2} \mathrm{OH}\right)\right]$ & 26 & 7 & 1 & $12 \mathrm{w}$ \\
\hline$\left[\left(\mathrm{Me}_{3} \mathrm{P}\right)_{3} \mathrm{Ru}(\mathrm{l}-\mathrm{OH})_{3} \mathrm{Ru}\left(\mathrm{PMe}_{3}\right)_{3}\right][\mathrm{OPh}]$ & 10 & 5 & 1 & $8 \mathrm{c}$ \\
\hline$\left[\mathrm{RuCl}_{2}\left(\eta^{6}-p\right.\right.$-cymene $)\left\{\mathrm{P}\left(4-\mathrm{C}_{6} \mathrm{H}_{4} \mathrm{~F}\right)_{2} \mathrm{Cl}\right\}$ & 0 & 31 & 0 & $6 \mathrm{j}$ \\
\hline $\begin{array}{c}\mathrm{Ru}(p \text {-cymene }) \mathrm{LCl}(\mathrm{HL}=2-(5,6 \text { - dihydro- } 4 \mathrm{H}-1,3 \text {-oxazin-2- } \\
\text { yl)phenol }))\end{array}$ & 11 & 0 & 0 & $7 b$ \\
\hline $\mathrm{RuCl}_{2}(\mathrm{PTA})_{4}$ & 9 & 1 & 0 & $6 \mathrm{k}$ \\
\hline$\left[\mathrm{RuCl}_{2}\left(\eta^{6}\right.\right.$-arene $\left.) \mathrm{PFu}_{3}\right]$ & 29 & 4 & 1 & 61 \\
\hline $\mathrm{RuH}(\mathrm{CO})(\mathrm{PNP})$ & 24 & 7 & 1 & $7 \mathrm{c}$ \\
\hline$\left[\mathrm{Os}(\mathrm{CO})_{3} \mathrm{Cl}_{2}\right]_{2}$ & 0 & 1 & 0 & $26 \mathrm{a}$ \\
\hline$\left[\mathrm{OsCl}_{2}(\text { azole })_{2}(\mathrm{dmso})_{2}\right]\left[\mathrm{OsCl}_{2}(\right.$ azole $\left.)(\mathrm{dmso})_{3}\right]$ & 0 & 5 & 0 & $11 \mathrm{a}$ \\
\hline RuII- and OsII-arene & 0 & 3 & 0 & $11 b$ \\
\hline$\left[\mathrm{Os}\left(\eta^{6}-p\right.\right.$-cymene $\left.)(\mathrm{OH}) \operatorname{IPr}\right] \mathrm{OTf}$ & 7 & 5 & 0 & 25 \\
\hline$\left[\mathrm{OsCl}_{2}\left(\eta^{6}-p\right.\right.$-cymene $\left.)\left(\mathrm{PMe}_{2} \mathrm{OH}\right)\right]$ & 20 & 8 & 1 & $26 b$ \\
\hline$\left[\mathrm{OsCl}_{2}\left(\eta^{6}\right.\right.$ - $p$-cymene $\left.)\left\{\mathrm{PPh}_{2}\left(\mathrm{NMe}_{2}\right)\right\}\right]$ & 17 & 8 & 0 & $6 \mathrm{~h}$ \\
\hline$\left[\mathrm{Co}(\text { cyclen })\left(\mathrm{OH}_{2}\right)_{2}\right]^{3+}$ & 0 & 1 & 0 & $13 b$ \\
\hline $\mathrm{Rh}(\mathrm{COD})\left(\kappa-\mathrm{C}_{2}-\mathrm{PIN}\right) \mathrm{Br}$ & 12 & 6 & 3 & $11 \mathrm{e}$ \\
\hline$\left[\mathrm{RhCl}(\mathrm{COD})\left\{\mathrm{P}\left(\mathrm{NMe}_{2}\right)_{3}\right\}\right.$ & 17 & 7 & 0 & $6 \mathrm{~g}$ \\
\hline $\mathrm{RhCl}(\mathrm{cod})$ (IMes) & 7 & 0 & 0 & $9 \mathrm{f}$ \\
\hline$\left[\mathrm{Ir}\left(\mathrm{O}_{2}\right)\left(\mathrm{PMe}_{3}\right)_{4}\right] \mathrm{Cl}$ & 0 & 1 & 0 & $11 \mathrm{c}$ \\
\hline $\mathrm{Cp} * \mathrm{IrClL}$ & 13 & 3 & 0 & 18 \\
\hline$(\mathrm{PCP}) \mathrm{Ni}-\mathrm{OH}$ & 5 & 4 & 3 & $9 \mathrm{~d}$ \\
\hline NiI(II) N-heterociclic carbenes & 15 & 5 & 2 & $13 d$ \\
\hline$\left(\mathrm{PN}_{3} \mathrm{P}\right) \mathrm{Ni}(\mathrm{COOH})$ & 3 & 2 & 1 & $9 \mathrm{e}$ \\
\hline trans- $\mathrm{PtHCl}\left(\mathrm{PMe}_{3}\right)_{2}$ & 0 & 1 & 1 & $13 \mathrm{a}$ \\
\hline $\mathrm{PtH}\left(\mathrm{PMe}_{2} \mathrm{OH}\right)\left(\mathrm{PMe}_{2} \mathrm{O}\right)_{2} \mathrm{H}$ & 1 & 2 & 1 & $16 \mathrm{a}$ \\
\hline
\end{tabular}




\begin{tabular}{ccccc}
$\mathrm{PtH}\left(\mathrm{PMe}_{2} \mathrm{OH}\right)\left(\mathrm{PMe}_{2} \mathrm{O}\right)_{2} \mathrm{H}$ & 1 & 1 & 1 & $16 \mathrm{~b}$ \\
$\mathrm{PtH}\left(\mathrm{PMe}_{2} \mathrm{OH}\right)\left(\mathrm{PMe}_{2} \mathrm{O}\right)_{2} \mathrm{H}$ & 2 & 5 & 0 & $16 \mathrm{c}$ \\
$(\mathrm{DPPF}) \mathrm{PtCl}_{2}, \mathrm{PMe} \mathrm{PMH}_{2}$ and $\mathrm{AgOTf}$ & 6 & 14 & 0 & 17 \\
$\mathrm{Pt}(\mathrm{COD}) \mathrm{Cl}_{2}$ & 9 & 2 & 0 & $7 \mathrm{a}$ \\
$\mathrm{Pd}(\mathrm{OAc})_{2} / \mathrm{Sc}_{(\mathrm{OTf}}$ & 15 & 3 & 0 & $11 \mathrm{f}$ \\
$\mathrm{Cu} 4 \mathrm{H}_{4}\left(\mathrm{H}_{2} \mathrm{O}\right)_{4}$ & 11 & 3 & 1 & $6 \mathrm{e}$ \\
$\mathrm{CuO}$ & 13 & 2 & 0 & $6 \mathrm{f}$ \\
$(\mathrm{IPr}) \mathrm{Au}(\mathrm{NTf})$ & 22 & 3 & 3 & $9 \mathrm{~b}$ \\
{$\left[\{\mathrm{Au}(\mathrm{NHC})\}_{2}(\mu-\mathrm{OH})\right]\left[\mathrm{BF}_{4}\right]$} & 1 & 0 & 0 & $9 \mathrm{c}$ \\
\hline
\end{tabular}

${ }^{a}$ The numbers correspond to the references shown in the article.

Table S2. Conditions for de catalytic hydration of acetonitrile with different catalyst.

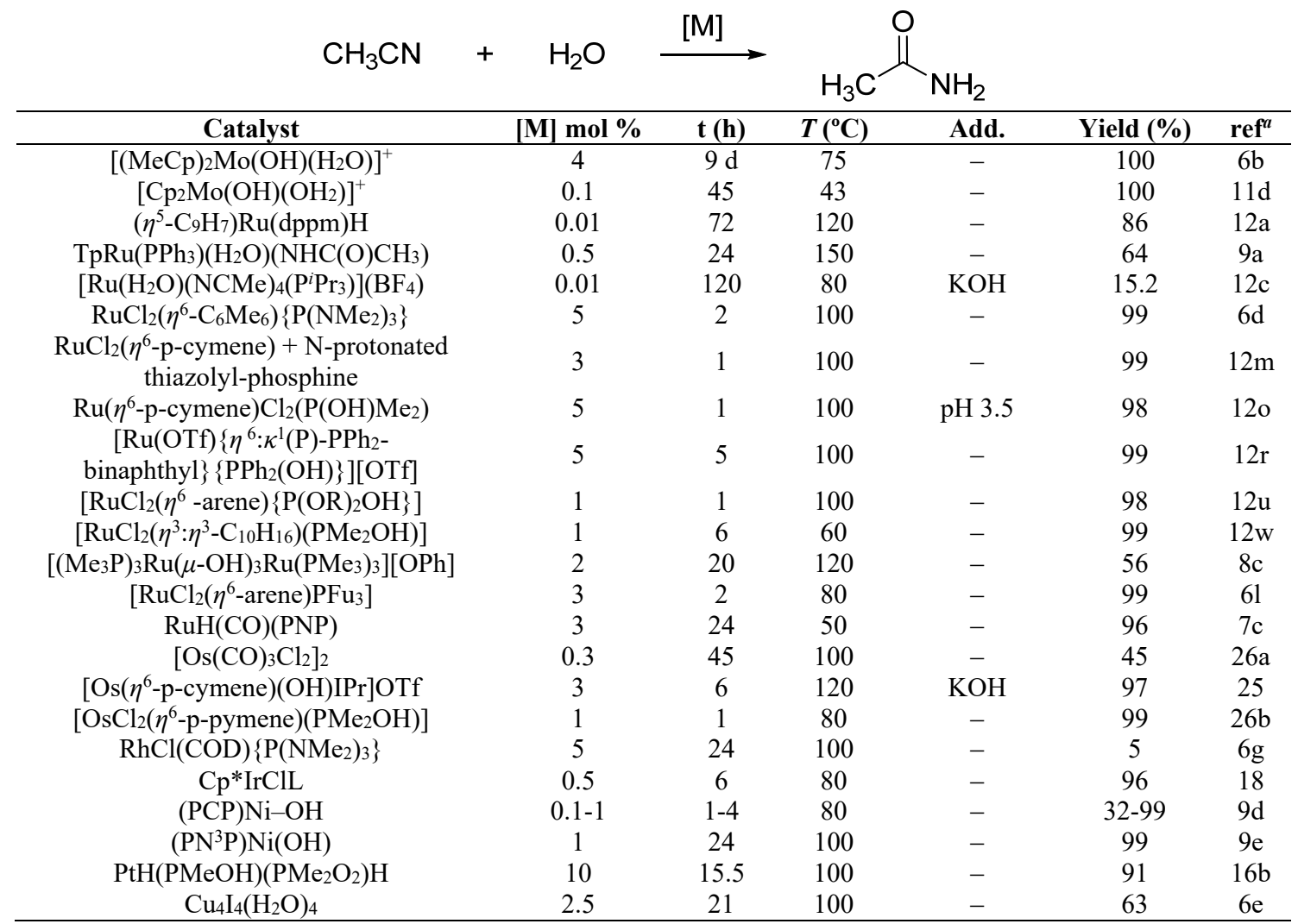

${ }^{a}$ The numbers correspond to the references shown in the article. 
Table S3. Catalytic conditions for hydration of linear chain nitriles

\begin{tabular}{|c|c|c|c|c|c|c|}
\hline $\mathrm{n}=4,5,6$ & & & & & & \\
\hline Catalyst & {$[\mathrm{M}] \mathrm{mol} \%$} & t (h) & $T\left({ }^{\circ} \mathrm{C}\right)$ & Add. & Yield (\%) & ref $^{a}$ \\
\hline $\mathrm{Na}_{2} \mathrm{MoO}_{4}-2 \mathrm{H}_{2} \mathrm{O}$ & 10 & 12 & 100 & acetaldoxime & 87 & 10 \\
\hline cis-Ru(acac $)_{2}-\left(\mathrm{PPh}_{2} \mathrm{py}\right)_{2}$ & 0.2 & 0.5 & 180 & - & 93 & $8 \mathrm{a}$ \\
\hline$\left[\mathrm{RuCl}_{2}\left(\eta^{6}-\mathrm{C}_{6} \mathrm{Me}_{6}\right)(\mathrm{PTA}-\mathrm{Bn})\right]$ & 5 & 8 & 100 & - & 95 & $12 \mathrm{~b}$ \\
\hline$\left.\left[\left(\mathrm{Pcy}_{3}\right)(\mathrm{CO}) \mathrm{RuH}\right]_{4}\left(\mu^{4}-\mathrm{O}\right)\left(\mu^{3}-\mathrm{OH}\right)\left(\mu^{2}-\mathrm{OH}\right)\right\}$ & 1 & 12 & 90 & - & 78 & $13 \mathrm{c}$ \\
\hline $\mathrm{TpRu}\left(\mathrm{PPh}_{3}\right)\left(\mathrm{H}_{2} \mathrm{O}\right)\left(\mathrm{NHC}(\mathrm{O}) \mathrm{CH}_{3}\right)$ & 0.5 & 24 & 150 & - & 31 & $9 \mathrm{a}$ \\
\hline $\begin{array}{c}{\left[\mathrm{RuCl}_{2}\left\{\kappa^{1}(\mathrm{P})-3-\mathrm{Ph}_{2} \mathrm{PC}_{6} \mathrm{H}_{4} \mathrm{CH}_{2} \mathrm{NHR}\right\}-\left(\eta^{6}-\right.\right.} \\
\text { arene })]\end{array}$ & 5 & 24 & 100 & & 55 & $12 \mathrm{~d}$ \\
\hline$\left[\left\{\mathrm{RuCl}_{2}\left(\eta^{3}: \eta^{3}-\mathrm{C}_{10} \mathrm{H}_{16}\right)\right\}_{2}(\mathrm{THPA})\right]$ & 5 & 24 & 100 & - & 94 & $12 \mathrm{e}$ \\
\hline$\left[\mathrm{RuCl}_{2}\left(\eta^{6}-\mathrm{C}_{6} \mathrm{Me}_{6}\right)\left\{\mathrm{P}\left(\mathrm{Nme}_{2}\right)_{3}\right\}\right]$ & 5 & 4 & 100 & - & 97 & $6 \mathrm{~d}$ \\
\hline$\left[\mathrm{Ru}(\text { methallyl })_{2}(\mathrm{cod})\right]+$ pyridylphosphine & 1 & 5 & 80 & - & 99 & $12 \mathrm{~h}$ \\
\hline $\mathrm{RuCl}_{2}(\mathrm{PTA})_{4}$ & 5 & 7 & 100 & - & 72 & $12 \mathrm{i}$ \\
\hline $\begin{array}{c}\mathrm{RuCl}_{2}\left(\eta^{6} \text {-p-cymene }\right)+\mathrm{N} \text {-protonated } \\
\text { thiazolyl-phosphine }\end{array}$ & 3 & 7 & 100 & - & 99 & $12 \mathrm{~m}$ \\
\hline $\begin{array}{c}{\left[\left(\eta^{6}-\mathrm{C}_{6} \mathrm{H}_{5} \mathrm{CH}_{3}\right) \mathrm{RuCl}\left(\kappa^{2}-(\mathrm{P}, \mathrm{N}) \mathrm{PTA}-\right.\right.} \\
\left.\left.\mathrm{CPh}_{2} \mathrm{NHPh}\right)\right] \mathrm{Cl}\end{array}$ & 5 & 24 & 100 & - & 62 & $12 p$ \\
\hline $\begin{array}{c}{\left[\mathrm{Ru}(\mathrm{Otf})\left\{\eta^{6}: \kappa^{1}(\mathrm{P})-\mathrm{PPh}_{2-}\right.\right.} \\
\left.\text { binaphthyl }\}\left\{\mathrm{PPh}_{2}(\mathrm{OH})\right\}\right][\mathrm{Otf}]\end{array}$ & 5 & 6 & 100 & - & 99 & $12 \mathrm{r}$ \\
\hline$\left(\eta^{6}\right.$-toluene) $\mathrm{RuCl}_{2}\left(\mathrm{PTA} \mathrm{P}^{\mathrm{i}} \mathrm{Pr}_{2}\right)$ & 5 & 24 & 100 & - & 74 & $12 \mathrm{t}$ \\
\hline $\operatorname{RuCl}\left(\eta^{6}\right.$-p-cymene $)\left\{\mathrm{P}\left(4-\mathrm{C}_{6} \mathrm{H}_{4} \mathrm{~F}\right)_{2} \mathrm{Cl}\right\}$ & 2 & 6 & 100 & - & 99 & $12 \mathrm{v}$ \\
\hline $\mathrm{RuCl}_{2}\left(\eta^{3}: \eta^{3}-\mathrm{C}_{10} \mathrm{H}_{16}\right)\left(\mathrm{PMe}_{2} \mathrm{OH}\right)$ & 1 & 6 & 60 & - & 97 & $12 \mathrm{w}$ \\
\hline$\left[\mathrm{RuCl}_{2}(\mathrm{PTA})_{4}\right]$ & 5 & 24 & 100 & - & 99 & $6 \mathrm{k}$ \\
\hline$\left[\mathrm{RuCl}_{2}\left(\eta^{6}\right.\right.$-arene $\left.) \mathrm{PFu}_{3}\right]$ & 3 & 2 & 80 & - & 99 & 61 \\
\hline$\left[\mathrm{OsCl}_{2}\left(\eta^{6}\right.\right.$-p-cymene $\left.)\left(\mathrm{PMe}_{2} \mathrm{OH}\right)\right]$ & 1 & 1 & 80 & - & 99 & $26 b$ \\
\hline$\left[\mathrm{OsCl}_{2}\left(\eta^{6}\right.\right.$-p-cymene $\left.)\left\{\mathrm{PPh}_{2}\left(\mathrm{NMe}_{2}\right)\right\}\right]$ & 1 & 4 & 100 & - & 99 & $6 i$ \\
\hline $\mathrm{RhCl}(\mathrm{COD})\left\{\mathrm{P}\left(\mathrm{NMe}_{2}\right)_{3}\right\}$ & 5 & 24 & 100 & - & 12 & $6 \mathrm{~g}$ \\
\hline$\left[\mathrm{Rh}(\mathrm{COD})\left(\kappa-\mathrm{C}_{2}-\mathrm{PIN}\right) \mathrm{Br}\right]$ & 0.5 & 6 & 25 & ${ }^{\mathrm{t}} \mathrm{BuOK}$ & 75 & $11 \mathrm{e}$ \\
\hline $\mathrm{Pd}(\mathrm{OAc})_{2} / \mathrm{Sc}(\mathrm{OTf})_{3}$ & $5 / 10$ & 12 & 70 & $\mathrm{AcOH}$ & 67 & $11 \mathrm{f}$ \\
\hline $\mathrm{CuO}$ & 10 & 12 & 100 & acetaldoxime & 90 & $6 \mathrm{f}$ \\
\hline
\end{tabular}

${ }^{a}$ The numbers correspond to the references shown in the article.

Table S4. Catalytic conditions for hydration of branched chain nitriles

\begin{tabular}{|c|c|c|c|c|c|c|}
\hline Catalyst & {$[\mathrm{M}] \mathrm{mol} \%$} & t (h) & $T\left({ }^{\circ} \mathrm{C}\right)$ & Add. & Yield (\%) & ref $^{a}$ \\
\hline$\left[(\mathrm{MeCp})_{2} \mathrm{Mo}(\mathrm{OH})\left(\mathrm{H}_{2} \mathrm{O}\right)\right]^{+}$ & 4 & $13 \mathrm{~d}$ & 85 & - & 100 & $6 \mathrm{~b}$ \\
\hline$\left[\mathrm{RuCl}_{2}\left(\eta^{6}-\mathrm{C}_{6} \mathrm{Me}_{6}\right)(\mathrm{PTA}-\mathrm{Bn})\right]$ & 5 & 5 & 100 & - & 98 & $12 b$ \\
\hline$\left.\left[\left(\mathrm{Pcy}_{3}\right)(\mathrm{CO}) \mathrm{RuH}\right]_{4}\left(\mu^{4}-\mathrm{O}\right)\left(\mu^{3}-\mathrm{OH}\right)\left(\mu^{2}-\mathrm{OH}\right)\right\}$ & 1 & 12 & 90 & - & 84 & $13 \mathrm{c}$ \\
\hline $\mathrm{TpRu}\left(\mathrm{PPh}_{3}\right)\left(\mathrm{H}_{2} \mathrm{O}\right)\left(\mathrm{NHC}(\mathrm{O}) \mathrm{CH}_{3}\right)$ & 0.5 & 24 & 150 & - & 50 & $9 \mathrm{a}$ \\
\hline$\left[\left\{\mathrm{RuCl}_{2}\left(\eta^{3}: \eta^{3}-\mathrm{C}_{10} \mathrm{H}_{16}\right)\right\}_{2}(\mathrm{THPA})\right]$ & 5 & 24 & 100 & - & 83 & $12 \mathrm{e}$ \\
\hline $\mathrm{Ru}\left(\eta^{6}\right.$-p-cymene $) \mathrm{Cl}_{2}\left(\mathrm{P}(\mathrm{OH}) \mathrm{Me}_{2}\right)$ & 5 & 7.5 & 100 & $\mathrm{pH} 3.5$ & 74 & 120 \\
\hline $\begin{array}{c}{\left[\mathrm{Ru}(\mathrm{OTf})\left\{\eta^{6}: \kappa^{1}(\mathrm{P})-\mathrm{PPh}_{2-}\right.\right.} \\
\left.\text { binaphthyl }\}\left\{\mathrm{PPh}_{2}(\mathrm{OH})\right\}\right][\mathrm{OTf}]\end{array}$ & 5 & 24 & 100 & - & 91 & $12 \mathrm{r}$ \\
\hline $\mathrm{RuCl}_{2}(\mathrm{dmso})_{4}$ and $\left[\left(\eta^{6}-p \text {-cymene }\right) \mathrm{RuCl}_{2}\right]_{2}$ & 5 & 1 & 100 & $($ pta-Bn)Cl & 97 & $12 \mathrm{~s}$ \\
\hline $\mathrm{RuH}(\mathrm{CO})(\mathrm{PNP})$ & 3 & 24 & 50 & - & 99 & $7 \mathrm{c}$ \\
\hline$\left[\mathrm{Os}\left(\eta^{6}\right.\right.$-p-cymene $\left.)(\mathrm{OH}) \mathrm{IPr}\right] \mathrm{OTf}$ & 3 & 16 & 120 & $\mathrm{KOH}$ & 97 & 25 \\
\hline$\left[\mathrm{OsCl}_{2}\left(\eta^{6}\right.\right.$-p-cymene $\left.)\left(\mathrm{PMe}_{2} \mathrm{OH}\right)\right]$ & 1 & 1.5 & 80 & - & 99 & $26 b$ \\
\hline$\left[\mathrm{OsCl}_{2}\left(\eta^{6}\right.\right.$-p-cymene $\left.)\left\{\mathrm{PPh}_{2}\left(\mathrm{NMe}_{2}\right)\right\}\right]$ & 1 & 2.5 & 100 & - & 99 & $6 i$ \\
\hline $\mathrm{Cp}$ *IrClL & 0.5 & 6 & 80 & - & 95 & 18 \\
\hline (PCP)Ni-OH & $0.1-1.0$ & $1-4$ & 80 & - & $47-99$ & $9 \mathrm{~d}$ \\
\hline$(\mathrm{IPr}) \mathrm{Au}\left(\mathrm{NTf}_{2}\right)$ & 5 & 6 & 140 & MW & 70 & $9 \mathrm{~b}$ \\
\hline
\end{tabular}

${ }^{a}$ The numbers correspond to the references shown in the article. 
Table S5. Catalytic conditions for hydration of pivalonitrile

\begin{tabular}{|c|c|c|c|c|c|c|}
\hline Catalyst & {$[\mathrm{M}] \mathrm{mol} \%$} & t (h) & $T\left({ }^{\circ} \mathrm{C}\right)$ & Add. & Yield (\%) & ref $^{a}$ \\
\hline$c i s-\mathrm{Ru}(\mathrm{acac})_{2}-\left(\mathrm{PPh}_{2} \mathrm{py}\right)_{2}$ & 0.2 & 0.5 & 180 & - & 75 & $8 \mathrm{a}$ \\
\hline $\mathrm{RuCl}_{2}(\mathrm{PTA})_{4}$ & 5 & 7 & 100 & - & 67 & $12 \mathrm{i}$ \\
\hline $\mathrm{Ru}\left(\eta^{6}\right.$-p-cymene $) \mathrm{Cl}_{2}\left(\mathrm{P}(\mathrm{OH}) \mathrm{Me}_{2}\right)$ & 5 & 7.5 & 100 & $\mathrm{pH} 3.5$ & 90 & 120 \\
\hline$\left[\left(\eta^{6}-\mathrm{C}_{6} \mathrm{H}_{5} \mathrm{CH}_{3}\right) \mathrm{RuCl}\left(\kappa^{2}-(P, N) \mathrm{PTA}-\mathrm{CPh}_{2} \mathrm{NHPh}\right)\right] \mathrm{Cl}$ & 5 & 24 & 100 & - & 79 & $12 \mathrm{p}$ \\
\hline $\mathrm{RuH}(\mathrm{CO})(\mathrm{PNP})$ & 3 & 24 & 50 & - & 96 & $7 \mathrm{c}$ \\
\hline$\left[\mathrm{Rh}(\mathrm{COD})\left(\kappa-\mathrm{C}_{2}-\mathrm{PIN}\right) \mathrm{Br}\right]$ & 0.5 & 24 & 25 & ${ }^{t} \mathrm{BuOK}$ & 38 & $11 \mathrm{e}$ \\
\hline $\mathrm{Cp} * \operatorname{IrClL}$ & 0.5 & 16 & 80 & - & 97 & 18 \\
\hline$(\mathrm{PCP}) \mathrm{Ni}-\mathrm{OH}$ & $0.5-1.0$ & $6-8$ & 80 & - & 95 & $9 \mathrm{~d}$ \\
\hline
\end{tabular}

${ }^{a}$ The numbers correspond to the references shown in the article. 